\title{
LA ARCHIVÍSTICA Y LA CIENCIA DE LA INFORMACIÓN DOCUMENTAL autonomía e interdependencias
}

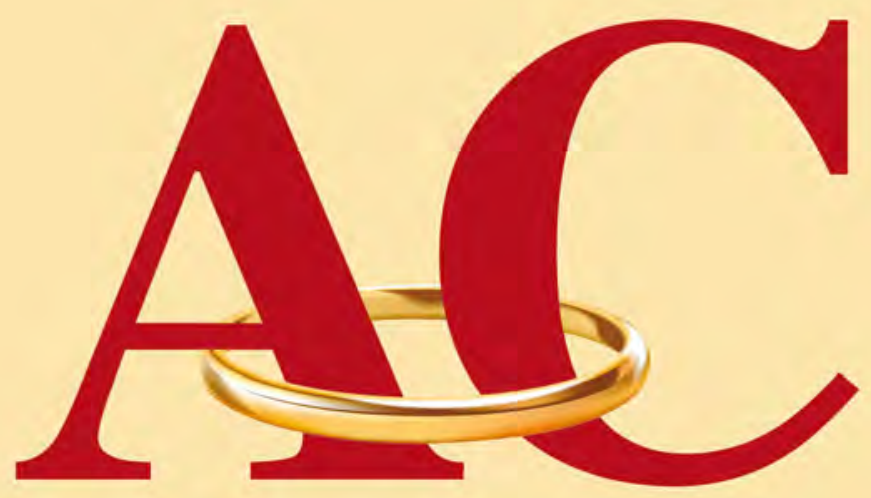

\author{
MigueL ÁNGEL \\ RENDÓN ROJAS \\ (coordinador)
}




\section{La presente obra está bajo una licencia de:}

\section{http://creativecommons.org/licenses/by-nc-sa/3.0/deed.es MX}

\section{Atribución-No Comercial-Licenciamiento Reciproco 3.0 Unported}

Eres libre de:

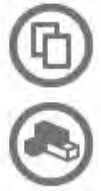

copiar, distribuir y comunicar públicamente la obra

hacer obras derivadas

Bajo las condiciones siguientes:

Atribución - Debes reconocer la autoría de la obra en los términos

especificados por el propio autor o licenciante.

No comercial - No puedes utilizar esta obra para fines comerciales.

Licenciamiento Recíproco - Si alteras, transformas o creas una obra a

partir de esta obra, solo podrás distribuir la obra resultante bajo una licencia

igual a ésta.

\section{Esto es un resumen fácilmente legible del: texto legal (de la licencia completa)}

En los casos que sea usada la presente obra, deben respetarse los términos especificados en esta licencia.
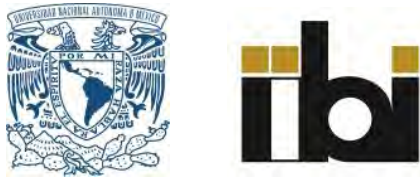


\section{La Archivística y la ciencia de la}

información documental Autonomía e interdependencias 


\title{
La Archivística y la ciencia de la información documental
}

Autonomía e interdependencias

\author{
Coordinador \\ Miguel Ángel Rendón Rojas
}

Universidad Nacional Autónoma de México 2017 


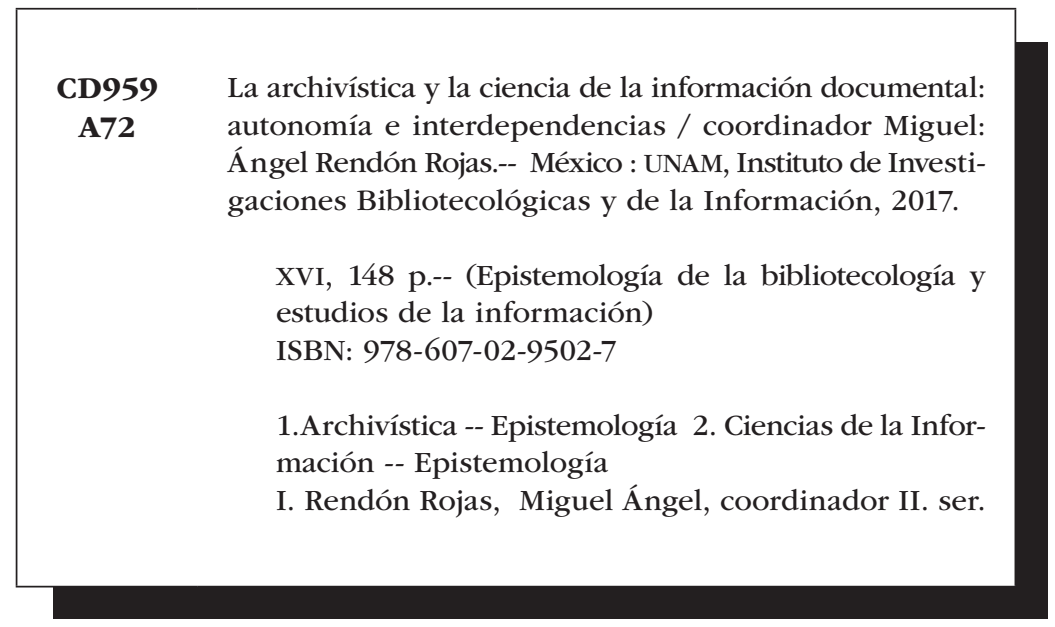

Diseño de portada: Mario Ocampo Chávez

Primera edición, 2017

D.R. (C) Universidad Nacional Autónoma de México

Ciudad Universitaria, 04510, México D.F.

Impreso y hecho en México

ISBN: 978-607-02-9502-7

Publicación dictaminada 


\section{Contenido}

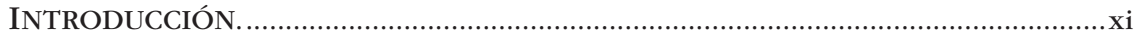

Miguel Ángel Rendón Rojas

LA CIENCIA DE LA INFORMACIÓN Y EL FENÓMENO

DE LO TRANSDISCIPLINARIO

1

Ariel Morán Reyes

LA ERA POSCUSTODIAL: IMPLICACIONES EN

EL CAMPO DE LA CIENCIA DE LA INFORMACIÓN.

23

Fernanda Ribeiro

LA PERMANENTE DEFENSA DE LA ARCHIVÍSTICA

POR SU AUTONOMÍA.

Silvana Elisa Cruz Domínguez

APUNTES SOBRE LOS FUNDAMENTOS

CIENTÍFICOS DE LA ARCHIVÍSTICA

Merizanda M. C. Ramírez Aceves

CIÊNCIA DA INFORMAÇÃO E ARQUIVOLOGIA:

ÁREAS DO CONHECIMENTO?.

Angélica Alves da Cunha Marques

MÁS ALLÁ DE LO INMEDIATO. HACIA LA

FUNDAMENTACIÓN DE LA ARCHIVÍSTICA

REFLEXIONES FINALES.

119

Miguel Ángel Rendón Rojas 


\section{Introducción}

L

a investigación en torno a la epistemología de la Bibliotecología y Estudios de la Información nos ha llevado a comprender este campo de conocimiento no desde una perspectiva restringida, como el estudio del fenómeno de las bibliotecas, lo bibliotecario, sus componentes y actividades, sino dentro de una visión más amplia como el estudio del mundo informativo documental en general, lo que a su vez nos ha conducido a volver la mirada y centrar nuestra atención en las "disciplinas afines" -Archivística, Ciencia de la Información y Documentación- y preguntarnos por cuestiones epistemológicas de cada una de ellas así como por las relaciones que existen entre estas disciplinas.

En 2011, vio la luz el libro colectivo Bibliotecología, archivística, documentación: intradisciplina, interdisciplina o transdisciplinariedad, producto del análisis y el diálogo llevado a cabo dentro del cuerpo académico de la licenciatura de Ciencias de la Información Documental de la Universidad Autónoma del Estado de México (UAEM) por la iniciativa y bajo la coordinación del autor de estas líneas y que indagaba en las siguientes problemáticas:

¿existe una ciencia de la información documental o son varias las ciencias de la información documental? [...] ¿Cuál es el estatus científico de la Bibliotecología, la Archivística y la Documentación? ¿Son 
ciencias independientes en sí mismas o son disciplinas de una ciencia general? ¿Cuál es la relación que guardan la Bibliotecología, la Archivística y la Documentación en el sentido de si existe intradisciplinariedad o transdiciplinariedad; complementación, inclusión o subordinación ${ }^{1}$

Una de las conclusiones de esa obra menciona la necesidad de continuar con el estudio de esas problemáticas, por lo que dentro del Seminario de Epistemología de la Bibliotecología y Estudios de la Información que se lleva a cabo en el Instituto de Investigaciones Bibliotecológicas (IIBI) y de la Información de la Universidad Nacional Autónoma de México (UNAM), presentamos como tema de discusión el lugar de la Archivística dentro del cuerpo de conocimientos informativo-documentales, sus características específicas y su relación con ese campo de conocimiento.

No es difícil advertir la importancia que una reflexión de este tipo representa. Además de las implicaciones estrictamente teóricas y epistemológicas que permiten un mayor autoconocimiento de la Archivística, tampoco podemos dejar de mencionar la cuestión práctica en lo referente a la formación profesional de los especialistas encargados de trabajar en el campo. De acuerdo con la concepción de lo que es la Archivística y las funciones que cumple, se estipularán los objetivos y contenidos que se asignarán a los Planes y Programas de estudio en esta área. Si tenemos en consideración el papel preponderante que la información juega en la sociedad contemporánea, sabremos que es de gran importancia que los profesionales que tienen su objeto de estudio y materia de trabajo en la información y documentación archivística estén debidamente preparados para responder a los retos que les plantea la realidad actual.

La presente obra colectiva es el producto de las visiones que los participantes del Seminario aportaron sobre el tema. En un primer momento, el licenciado Ariel Morán, del Programa de Posgrado en

1 Miguel Ángel Rendón Rojas, coord. Bibliotecología, Archivística, documentación: intradisciplina, interdisciplina o transdisciplinariedad (México: CUIBUNAM), XVII. 
Bibliotecología y Estudios de la Información de la UNAM, nos presenta el trabajo "La ciencia de la información y el fenómeno de lo transdisciplinario", en el que afirma que la Ciencia de la Información, debido a su carácter constitutivo, puede servir como puente de diálogo entre las disciplinas informativas y documentales, y dejar de lado la intención de constituir una disciplina unitaria.

Por su parte, la doctora Fernanda Ribeiro, profesora del Centro de Estudios de las Tecnologías y Ciencias de la Comunicación (CETAC/ MEDIA) de la Facultad de Letras de la Universidad de Porto, distingue dos momentos en el desarrollo de la Biblioteconomía y Archivística. En su trabajo intitulado "La era post-custodial: implicaciones en el campo de la Ciencia de la Información" señala que desde el siglo XIX y primera mitad del XX, se consolidó una visión tradicional en las ciencias documentales. A dicha visión, la denomina "custodial, historicista, patrimonialista y tecnicista" y se caracterizaba porque el objeto de estudio era el documento concebido como una entidad estática, identificado con mensajes registrados en papel, y la misión principal del bibliotecario o archivero era guardar, conservar y organizar los fondos documentales. Posteriormente, debido principalmente a la estrecha relación entre la información y la tecnología digital, se cuestionó esa visión inicial y surgió otra que denomina post-custodial, científico-informacional. En este nuevo enfoque o, siguiendo la terminología kuhniana, este nuevo paradigma, el objeto de estudio y de trabajo es la información. La Archivística, así como la Biblioteconomía, dejan de ser técnicas con características específicas para llegar a ser disciplinas aplicadas del área de la Ciencia de la Información, y los profesionales de la información se convierten en gestores de información. Al mismo tiempo, como comparten el objeto de estudio y las metodologías, el archivista, el bibliotecario y el documentalista se funden en un nuevo profesional que sintetiza las diversas competencias de esos profesionales y se convierte en un especialista cuyo campo de acción es el flujo informacional que tiene lugar en diversas organizaciones.

En un tercer momento, podemos leer el trabajo "La permanente defensa de la archivística por su autonomía”, de la doctora Silvana Elisa Cruz Domínguez, de la Facultad de Humanidades de la UAEM. 
En su trabajo, la doctora Cruz Domínguez afirma que desde sus orígenes y hasta la actualidad, la práctica y la teoría archivística han estado vinculadas a otras disciplinas. De esta manera, en sus inicios, en el periodo que llama precientífico, cuando la Archivística sólo consistía en un conjunto de prácticas empíricas, ya estaba al servicio de la administración pública o privada; posteriormente creó vínculos con el Derecho, la Historia, la Diplomática y la Filología. A causa de esa permanente relación de la Archivística con otras disciplinas, ha estado siempre presente la necesidad, casi obsesiva, remarca la autora, de deslindarse de ellas y de demostrar su autonomía como ciencia. Sin embargo, en el momento actual, cuando según Cruz Domínguez, por influencia de pensadores posmodernos se han visto cuestionados los principios archivísticos, es el momento para que la Archivística vuelva los ojos hacia sí misma, deje de insistir en su autonomía, que es una característica de la visión positivista del siglo XIX, y dedique sus esfuerzos a reflexionar en la multidisciplinariedad para atender los problemas que hoy la aquejan. La Archivística debe comprender que los documentos de archivo no garantizan infaliblemente la objetividad de la Historia ni de otras disciplinas, pues pueden ser manipulados para distorsionar la realidad pretérita y presente, y que tiene un compromiso con la memoria y la verdad. Si esto se olvida o niega, si se persiste en la cómoda postura de observador imparcial, entonces será posible la pérdida de la autonomía.

En cuarto lugar, encontramos el trabajo "Apuntes sobre los fundamentos científicos de la Archivística" de la doctora Merizanda Ramírez Aceves, también de la Facultad de Humanidades de la UAEM. En él, la postura de la autora desde un inicio queda de manifiesto al declarar que "está demostrado que existen métodos y principios [...] que la posicionan [a la Archivística] como una ciencia, aunque emergente para unos y consolidada para otros" que necesita modernizar muchos de sus conceptos o crear otros a fin de adecuarse a las transformaciones provocadas por la aparición de las tecnologías. En su escrito, Ramírez Aceves tienen el objetivo de responder cuestionamientos claves sobre la identidad de la Archivística, tales como ¿Cuál es su objeto de estudio? ¿Sobre cuáles principios descansan 
sus fundamentos y cuáles rigen su desarrollo teórico? ¿Cuáles métodos emplea en el desarrollo de su teoría? ¿Qué fines epistemológicos persigue? Respecto a la primera pregunta, responde que el objeto de estudio de la Archivística es el archivo y los fondos documentales. Asimismo afirma que la Archivística encuentra su fundamento en el principio de procedencia y que el método que utiliza es la gestión documental o tratamiento documental. Finalmente, el elemento teleológico de la Archivística es el de hacer recuperable la información para uso tanto de las instituciones administrativas, como de la investigación.

Posteriormente, tenemos el texto de la doctora Angélica Alves da Cunha Marques del Programa de Posgrado en Ciencia de la Información de la Universidad de Brasilia que lleva por título "Ciência da Informação e Arquivologia: áreas do conhecimento?” En su trabajo, la doctora Marques toma como hilo conductor para conocer las relaciones entre la Ciencia de la Información y la Archivología, como ella la denomina, no un análisis teórico de esas disciplinas, sino un hecho real, expresado en documentos que reflejan el "imaginario" de los dirigentes del órgano estatal brasileño que coordina la política científica y de investigación de ese país en diferentes cortes temporales. De esta manera investiga y da a conocer cómo se han clasificado la Ciencia de la Información y la Archivología en las Tablas de Áreas del Conocimiento (TACS) elaboradas por el Conselho Nacional de Desenvolvimento Científico e Tecnológico (CNPq) ${ }^{2}$ de Brasil. El camino elegido para resolver el problema de las relaciones de la Ciencia de la Información con la Archivología resulta interesante ya que nos muestra un panorama histórico de cómo han sido esas relaciones y sus cambios, pero al mismo tiempo nos proporciona información sobre la imagen social que se tiene de esas dos disciplinas. De este punto, se desprende otra cuestión además de la estrictamente epistemológica que tiene que ver con la sociología del conocimiento: ¿Cómo la sociedad, en este caso brasileña, ve esas disciplinas?, y ¿realmente el CNPq refleja las trayec-

2 Las siglas CNPq corresponden al acrónimo del nombre originario de esa institución estatal: Conselho Nacional de Pesquisa. 
torias históricas y las configuraciones actuales de la Ciencia de la Información y la Archivología? La autora concluye que todas las clasificaciones, incluyendo la de las ciencias, son imágenes sociales condensadas y representadas en esquemas que simplifican la realidad. Más que la división científica de grupos, las TACs en Brasil parecen desempeñar un papel enciclopédico con base en la afinidad de los objetos e instrumentos de investigación de las áreas de conocimiento sin dejar de respetar las singularidades de las disciplinas.

Para concluir el libro, ofrezco el trabajo "Más allá de lo inmediato. Hacia la fundamentación de la archivística. Reflexiones finales", de mi autoría, donde proporciono algunas ideas eje alrededor de las cuales será necesario seguir reflexionando, como la necesidad de continuar realizando un estudio epistemológico de la Archivística, construir un aparato teórico sólido alejado de los límites que imponen acercamientos meramente pragmáticos y técnicos, así como visiones que se apoyan en ideas sobre objetos concretos en lugar de conceptos, categorías y modelos. Se concibe la Archivística como una disciplina informativo documental cercana a otras disciplinas también informativo documentales como la Bibliotecología, la Ciencia de la Información, la Documentación y la Museología, en una relación de cercanía, no de absorción, subordinación, adición o yuxtaposición. En la segunda parte de ese escrito, se analiza el lugar que el Consejo Nacional de Ciencia y Tecnología (Conacyt) de México le asigna a la Archivística dentro de su clasificación de los campos de conocimiento, así como el que los investigadores eligen para su disciplina.

Así pues, a lo largo de las páginas de este libro el lector encontrará diferentes acercamientos a la Archivística como disciplina científica y sus relaciones con las otras disciplinas informativo documentales. Será tarea de los intérpretes que este material sirva de materia prima para construir nuevas informaciones y conocimientos; proporcionar nuevos temas de diálogo que conduzcan a nuevas comprensiones y consensos, y ampliar nuestros horizontes de interpretación. 


\title{
La Ciencia de la información y el fenómeno de lo transdisciplinario
}

\author{
ARIEL MORÁN \\ Posgrado en Bibliotecología y Estudios de la Información, UNAM
}

El principio único y la raíz de casi todas las imperfecciones de las ciencias es que, mientras que admiramos y exaltamos falsamente las fuerzas del espiritu humano, no buscamos en modo alguno los verdaderos auxiliares.

Francis Bacon, Novum organum

\section{INTRODUCCIÓN}

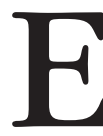
1 museo, la biblioteca y el archivo han vivido ciertos momentos de maridaje a través de los periodos históricos: en algunos lapsos coexistieron de manera manifiesta y en otros han aparentado estar conceptualmente alejados. En la actualidad, por ejemplo, parecen estar engarzados a través del elemento tecnológico, mismo que supone un fin para el tenor custodialista en estas instituciones. Por otra parte, a partir de su devenir histórico, es posible percatarse de que su estatus como instituciones de resguardo, paradójicamente, se ha decantado con un mayor énfasis hacia los objetos que hacia los documentos textuales (el libro, incluso, visto como objeto).

El museo (museion, Movøeĩov) fue el lugar en Alejandría, durante el siglo III, encomendado para el culto a las musas (culto a las artes y a las ciencias), que eran las hijas de Zeus y Mnemosine, la 
diosa de la memoria. Concretamente, se trataba de un conjunto de edificios construidos por la dinastía ptolemaica en su palacio real, como centro exclusivo para el cultivo y la conservación del conocimiento, en el cual se designaba un espacio para la biblioteca, pero además para un anfiteatro, un observatorio, salas de estudio, una colección zoológica y un almacén de minerales, entre otras áreas. El archivo se encontraba en el teatro; en la biblioteca se enseñaba y, además, se resguardaban los instrumentos y objetos para el estudio, por lo que el museo era en sí un centro de reunión para sabios y filósofos. Al conjunto de estos objetos se les denominaba thesaurus ( $\theta \eta \sigma \alpha v \rho o ́ \varsigma)$, es decir, el "almacén de los tesoros", en contraste con el actual uso de la palabra tesauro, que es el corpus de conceptos y relaciones terminológicas que permite analizar, interpretar y, seguidamente, acceder a los objetos de información (McCrank, 2001: 432-439). Dentro del museo, no existía propiamente una diferenciación categórica de acuerdo con el tipo de material o la temática, sino a partir de la necesidad de cada estudioso; dependiendo de esto, los materiales podían estar ubicados y dispuestos en las salas, el archivo o la biblioteca. Un ejemplo cercano a esta disposición conceptual del espacio es la Biblioteca Británica (la biblioteca imperial del Reino Unido), cuyo recinto es parte del Museo Británico.

Tras la conquista de los romanos, el contexto y concepto del $m u$ seion sufrió cambios. En primer lugar, la palabra museion se latinizó y enunció como museum, y pasó de ser un espacio que privilegiaba lo público para ponderar lo privado; en segundo lugar, tanto la biblioteca como el archivo, el observatorio y las salas de enseñanza se deslindaron de la institución para asumir papeles sociales específicos y disociados, por lo que al museo se le comenzó a emparentar con las pinacotecas, y se le miró entonces como el organismo que resguarda las colecciones de objetos culturales (sobre todo obras de arte).

Más allá de estos cambios, los archivos, las bibliotecas y los museos han sido las instituciones que han facilitado a sus respectivas comunidades el acceso a diversas representaciones de la información, además de que en la modernidad han promovido el avance cultural y educativo de la sociedad. Con el tiempo, se han convertido en elementos fundamentales para el asentamiento de las socie- 
dades democráticas. Hay que reconocer, empero, que a pesar de que archivos, bibliotecas y museos no han compartido, por un largo tiempo, la misma travesía, esta difuminación de las fronteras entre las instituciones del patrimonio cultural proporciona un entorno útil para explorar los esfuerzos de colaboración y acercamiento.

\section{LA CIENCIA DE LA INFORMACIÓN COMO PUENTE PARA LA DIALOGICIDAD}

Luego de la Segunda Guerra Mundial, y de los estragos que produjo, se generó en el mundo occidental un avance científico y tecnológico notable. Fue en este periodo cuando, de la inercia científica y tecnológica, nació la information science. El fenómeno de lo transdisciplinario produjo un efecto centrípeto sobre los métodos y procedimientos de las disciplinas informacionales (bibliotecología, documentación, archivología) que las conjuntó en una sola disciplina, pero generó un efecto centrífugo sobre los elementos de identidad de estas ciencias.

La "ciencia de la información" se conformó cuando el presidente de los Estados Unidos de América, Dwight Eisenhower, y su Comité Asesor de Ciencia - dirigido por James Rhyne Killian, Jr.-, se interesaron en el problema de la información científica luego de que los soviéticos lanzaran el satélite Sputnik 1 en 1957. El organismo encargado para documentar aquel programa de lanzamiento fue el Instituto de Información Científica y Tecnológica de la Unión Soviética -o VINITI por sus siglas en ruso (Vsesoyuznyy Institut Nauchnoy i Tekhnicheskoy Informatsii)—, una instancia creada en 1952 por la Academia de Ciencias de la Unión de Repúblicas Socialistas Soviéticas. Su equivalente en los Estados Unidos fue la Fundación Nacional para la Ciencia y la Oficina de Servicios Técnicos del Departamento de Comercio. Dicho Comité constituyó, a su vez, un subcomité especial encabezado por William Oliver Baker, vicepresidente de Investigación de Bell Telephone Laboratories, para abordar el problema del mejoramiento del acceso a la literatura científica, apoyados en las investigaciones de Claude Shannon, quien 
se había separado un año antes de los laboratorios (Burke, 2007: 36; Buckland y Liu, 1998: 274-275). Este comité incluso se llegó a teorizar sobre usos prometedores para un dispositivo de búsqueda basado en la factorización cuántica. La búsqueda inteligente de información permitiría a los usuarios de bases de datos documentales realizar un rastreo textual en sistemas de información utilizando frases y contexto, con lo que se reducirían las deficiencias que resultan de la multiplicidad de resultados carentes de sentido en contraste con los requerimientos de información. Sin embargo, esto se quedó en el terreno de la teorización. Las investigaciones de Claude Shannon sobre lógica booleana, códigos binarios y su implementación mediante circuitos eléctricos para la comunicación, fueron el detonante para instaurar los primeros catálogos automatizados de acceso público automatizados y su vínculo a bases de datos. La emergente Ciencia de la información también utilizó las ideas sobre flujo de información de Ralph Hartley y el mismo Claude Shannon para entramar su concepto información (Boyd, 1996: 5).

La institucionalización de la ciencia de la información y la principal referencia de su simiente se enclavan en el momento preciso en que las asociaciones profesionales de documentalistas comenzaron a adoptar los principios teóricos de esta nueva disciplina, y comenzaron a configurar sus valores ontológicos en torno a ella. Específicamente, se toma como momento referencial el cambio de nombre del American Documentation Institute por el de American Society for Information Science en 1968. En el año 2000, la asociación volvió a cambiar de nombre y adoptó un nuevo apellido para ser la American Society for Information Science and Technology. En el 2013, con la absorción del discurso del multiculturalismo, la entidad cambió otra vez de nombre por el actual: Association for Information Science and Technology (Travis, 2013: 2).

Pese a que la ciencia de la información retoma sus principios originarios de las prácticas documentales de finales del siglo XIX, el nominativo apareció al concluir la década de los cincuenta del siglo $\mathrm{XX}$, en estrecha conexión con el efervescente clima de las investigaciones en ciencia y tecnología. Los portugueses Armando Malheiro y Fernanda Ribeiro señalan que: 
Este nuevo campo de estudio, junto al trabajo desarrollado por las áreas tradicionales - la Archivística y la Bibliotecología-, surgieron como disciplinas científicas a mediados del siglo XIX en el marco del historicismo y el positivismo pero con un estatus de "auxiliares" de la historia, por lo que se caracterizaron por la erudición de alto nivel (Silva y Ribeiro, 2012: 169).

La revolución tecnológica de los años subsecuentes y la participación de la sociedad en el fenómeno de la información, ligada a los medios digitales, provocó profundos cambios en el campo de las disciplinas informacionales debido a la urgencia de dar respuestas a los nuevos desafíos, cuya aplicación exigía una solución cada vez más consistente, teórica y metodológicamente. Esta situación es la que, en múltiples ocasiones, desacelera el proceso de consolidación de las ciencias y produce la fragmentación de sus partes constitutivas. Dentro de la bibliotecología se intuyó que un cambio era apremiante frente al torrencial discurso tecnocrático, pero dicho cambio no implicó únicamente introducir el artefacto técnico a la formulación teórica de la práctica, aunque sí una reformulación derivada de la autocomprensión del profesional.

Pese al rápido crecimiento de la ciencia de la información, el consenso en torno a su naturaleza e identidad son, todavía hoy, un problema imbricado debido a que su constitución disciplinaria no se produjo al mismo tiempo ni de la misma manera en todos las regiones y, en consecuencia, su grado de desarrollo varía significativamente y hace difícil pensar en la unión en un solo campo. Aquí se evidencia la diferencia entre disciplina y campo: La disciplina se constituye por el conjunto de teorías y preceptos que fundamentan un quehacer científico, pero el campo es un estrato más amplio en el que la disciplina es el núcleo y alrededor de ella están otras actividades como la investigación, la agrupación en sociedades profesionales, la divulgación a través de publicaciones especializadas, la fundación y consolidación de escuelas, etcétera (ver Figura 1).

La ciencia de la información, como disciplina, tiene concertados una serie de conceptos que enarbolan su teoría fundamental (basada en la bibliotecología, la documentación y la archivística, principal- 
Figura 1.

Representación de los estratos disciplina y campo

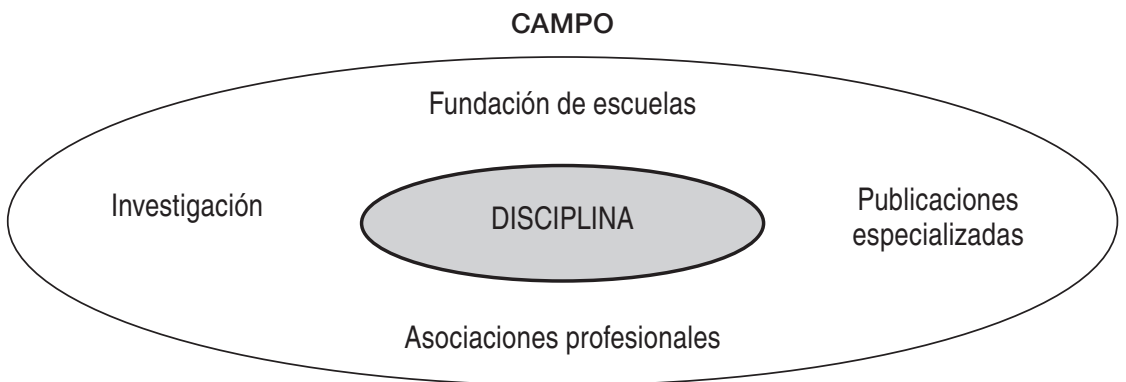

Fuente: elaboración propia.

mente), pero como campo adolece en algunos puntos, comenzando por el hecho de que intenta orquestar una serie de preceptos sin articularlos cabalmente. La cuestión es que, ciertamente, la disciplina es el núcleo de un campo, pero existen otras partes constitutivas que lo componen. Algunos teóricos como Jonathan Furner van más lejos y aseveran que la ciencia de la información ni es una ciencia ni trata preponderantemente sobre la información. En su análisis, la información es considerada desde varios flancos: como datos, contenidos, proposiciones, conocimiento, noticias (Furner, 2015: 362-364).

En términos generales -y probablemente de forma incompleta-, podría trazarse una secuencia histórica de la ciencia de la información, la cual comienza con el conocimiento operativo de los bibliotecarios y archivistas que como saber práctico es milenario. Estos agentes eminentemente operativos podrían ser identificados como el origen de la preocupación por las fuentes materiales dentro del mundo informativo-documental. Para los bibliotecarios y documentalistas, la ciencia de la información se refiere principalmente a la búsqueda de reglas más adecuadas para el diseño de sistemas y procedimientos encaminados a recopilar, almacenar, organizar, clasificar, indizar y recuperar aquellos materiales que soportan datos, conocimiento, significado y experiencia. Estos campos, entonces, atrajeron a los que trabajaban con información especializada, quienes 
generalmente forjaron su experiencia lindando en los terrenos del trabajo de los científicos (ciencia para la ciencia). Estas personas trajeron con ellos la preocupación por una mayor sistematicidad y formalismo con un empuje muy claro hacia clasificaciones más precisas y relaciones de indización más complejas. También desarrollaron la preocupación por el comportamiento del usuario y comenzaron con los estudios del comportamiento de la información.

Recientemente, este campo atrajo a administradores y científicos de la computación. La informática ha contribuido al dotar de un enfoque más turgente los asuntos relacionados con la recuperación de la información. El campo de la ciencia de la información, desde un inicio, comenzó a desarrollar diferentes manifestaciones o concepciones y muta conforme a ellas (Ribeiro, 2006: 165-166). De acuerdo con esta perspectiva canónica, y bajo el sentido de lo que es la corriente principal (el de la bibliotecología, la documentación y la archivística), todos los otros elementos podrían ser vistos como invasores del espacio, con lo que su propio bagaje, al conjuntarse con aquellos, hace que cambien su sentido y propósito central.

El denominativo "ciencia de la información" refiere a la disciplina que se consolidó en la década de los sesenta, y que buscó retomar los preceptos de la bibliotecología, la documentación y la archivística, y abrir así el abanico de aplicación de la práctica informativadocumental. Las "ciencias de la información", por otra parte, son las ciencias que sirvieron de fuente para la ciencia de la información, pero su enunciación denota una intención que no busca desmembrarlas y conformar una sola, sino seguir considerándolas como disciplinas autónomas y plenamente constituidas. Ambas expresiones ("ciencia de la información" y "ciencias de la información") son la respuesta a la diatriba transdisciplinaria. Por un lado, se asume el desafío inmediatista de la sociedad post-industrial, siguiendo cabalmente la inercia cientificista; por el otro lado, se admite una problemática y la posibilidad del cambio, pero no se propone que huyamos todos en bandada hacia el único bote disponible, sino aprovechar la circunstancia para robustecer los supuestos teóricos de cada disciplina, dialogar entre ellas, y reconocer métodos y procedimientos similares, cada cual con su enfoque particular. 
Reconocer una "ciencia de la información" de una manera sopesada puede ser útil para trazar un puente conceptual entre las disciplinas informativas y las documentales. Como ya se dijo anteriormente, la perspectiva purista de una ciencia de la información supone retomar los postulados más significativos de estas disciplinas y enconarlos hacia un solo discurso. No obstante, estudiarla de una forma ponderada podría ser apto para enarbolar la dialogicidad - la comprensión de uno y del otro- entre la bibliotecología, la documentación, la archivística, y acaso la museología.

\section{LAS INSTITUCIONES DE MEMORIA Y LA TRANSDICIPLINARIEDAD}

Desde mi visión, la perspectiva situada hacia la ciencia de la información abre una oportunidad valiosa, no para constituirla como una disciplina unitaria, sino que su carácter constitutivo puede servir como puente de diálogo entre las disciplinas informativas y las documentales. Por el contrario, los autores portugueses aludidos anteriormente señalan que:

La perspectiva que defendemos y hemos tratado de consolidar [...] asume a las ciencias de la información como un campo unitario del conocimiento, aún transdisciplinario, enclavada en el área general de las ciencias humanas y sociales, lo que da soporte teórico a disciplinas como la bibliotecología, la archivística, la documentación y algunos otros aspectos de la tecnología aplicada a los sistemas de información [...] En la perspectiva que defendemos, además de establecer los límites de la ciencia de la información, también definimos un objeto de estudio y asumimos un método de investigación adaptado a las características de la información como un fenómeno social, destacando su componente cualitativo, el cual es apropiado en el ámbito de las ciencias sociales (Silva y Ribeiro, 2012: 170).

Para el danés Birger Hjørland, los conceptos "documentos" e "instituciones de memoria" son términos genéricos para el objeto de 
estudio de las ciencias de la información (bibliotecología, documentación, archivística e, inclusive, la museología) (Hjørland, 2000: 28). Søren Brier, coterráneo de Hjørland, dice que:

La principal experticia de los bibliotecarios, archivistas y documentalistas siempre se ha condensado en el almacenamiento, la indización, la recuperación y la mediación de los materiales que transportan datos, conocimiento, significado y experiencia. Como ciencias, su objetivo ha sido, ante todo, promover la comunicación. Esto puede incluir los patrones para los registros, observaciones, conocimientos teóricos, así como significados, visiones o experiencias, frente a los medios de comunicación tales como documentos, libros, discos, cintas, programas informáticos, disquetes, discos compactos, hipertexto, imágenes, películas y videogramas, que van desde el productor hasta el usuario. Estas formas de mediación, y también las futuras, pueden resumirse bajo el concepto general, usado en la bibliotecología, de lo que es un "documento" (Brier, 2006: 6).

Por su parte, Sanjica Faletar y Boris Bosančić, de la Universidad de Osijek, atenúan que:

Archivos, bibliotecas y museos son instituciones del patrimonio cultural, o instituciones de memoria en sí, cuya misión es, en principio, la misma: organizar, preservar y facilitar el uso del patrimonio cultural y científico. A pesar del hecho de que se han centrado tradicionalmente en materiales de diferente formato (aunque no siempre), pese a que en sus quehaceres existen diferentes estándares profesionales y normas, las tareas y desafíos que enfrentan son similares (2005: 1).

Para Hjørland, los desafíos de la bibliotecología se resumen en los esfuerzos por erigir una institución de memoria, pero desde la perspectiva del usuario. Este autor cree que la creciente influencia de la tecnología en la ciencia de la información "ha puesto en duda el papel futuro de las bibliotecas tradicionales, archivos y otros tipos de instituciones de la memoria" (Hjørland, 2000: 31 y 38). La concep- 
tuación de la figura de "institución" en Hjørland no es plenamente fisicalista, ya que es amplia y abarca, incluso, la biblioteca metafórica. Como Borges, que habla de una Biblioteca (con mayúscula) que es el universo (esférica, interminable, que existe ab aterno), la cual está construida en proporciones hexagonales, casi como alusión a los polígonos platónicos. En el Timeo, Platón le otorga una forma geométrica a cada representación elemental de la materia: por ejemplo, el universo es un dodecaedro y la tierra un hexaedro. Héctor Alfaro también habla de una Biblioteca (en mayúscula) y de una biblioteca (en minúscula): la una es "todas las bibliotecas y a la vez ninguna", es la que da forma y sentido; la otra es la "específica y particular que tiene servicios determinados" (Alfaro López, 2011: 3-4). Joseph Nitecki basó la explicación de su postura filosófica para la bibliotecología en la idea de una meta-biblioteca (biblioteca metafórica) concebida como una esfera compuesta por un hexaedro interno y segmentado, y con relaciones en forma de hélices (Nitecki, 1993: 85-171).

La cuestión de la "memoria" en Hjørland se refiere al potencial que un documento tiene, de manera intrínseca, de ser consultado. Sin embargo, esto puede conducir al "anarchivo" derridiano. Una cuestión importante aquí es que los estudios de necesidades de información construyen su andamiaje sobre la idea de ese potencial de consulta (que no es lo mismo que el potencial informativo) o, en otras palabras, tejen la trama de la biblioteca a partir de la especulación, y ésta — dice Derrida- es el comienzo de la fabulación y, por ende, del mal de archivo. Esto puede ser sentenciado con lo dicho por el Zaratustra nietzscheano: "el que cree conocer al lector no hace ya nada por el lector" (Nietzsche, 1986: 35). Como prontuario, Derrida define el "anarchivo" como la obsesión del archivo, "la violencia del olvido", lo que se pierde o traslapa. Para el "maestro de la deconstrucción", estar en mal de archivo implica:

[...] interminablemente buscar el archivo allí donde se nos hurta. Es correr detrás de él allí donde [...] algo en él se anarchiva. Es lanzarse hacia él con un deseo compulsivo, repetitivo y nostálgico, un deseo irreprimible de retorno al origen, una morriña, una nos- 
talgia de retorno al lugar más arcaico del comienzo absoluto (Derrida: 1997,89$)$.

Desde este punto de vista, todo estudio que intenta acercarse a un documento que ha modificado su contexto (que se ha anarchivado) lleva consigo parte de esa nostalgia, pero sobre todo la obsesión por entender el acontecimiento que se ha quedado encapsulado en el papel o en la imagen; es decir, en lo físico.

Desde la visión noética de Tom Stonier, se entiende que la implementación física es sólo uno de los "rostros" de la información y, por ende, la representación física de la información debe ser sólo una primera aproximación a su estudio. La información es hilemórfica (forma y materia), como lo señaló el filósofo francés Gilbert Simondon en 1958. Algunas disciplinas, como muestra, exponen preponderantemente su "cara física", como la informática, pero esto no implica que sea la única cara. La posición intelectual de Stonier ha contribuido a dar forma a un nuevo concepto de la organización de la información, y también reformuló el concepto tradicional de "servicio de biblioteca", que era visto sólo como in situ. Stonier habló de un servicio sin las limitaciones del espacio físico, y se refirió más bien a un espacio lógico determinado por la organización del flujo de información (Stonier et al., 1990: 181-182). Para el emérito de la Universidad de Bradford, el servicio de la biblioteca no debe estar encapsulado por el espacio físico, sino que debe estar dispuesto por dos aspectos: el amplio espectro de los "flujos de información" (materiales o inmateriales, bien orquestados o caóticos) y por la lógica (ya sea dinámica, epistémica, modal, local) a través de un orden u organización en un sistema. El flujo de información que se da entre los distintos órdenes de magnitud permite considerar incluso a los seres vivientes como un sistema, es decir, como un ser en relación consigo mismo y con las variaciones de su medio.

Para Michael K. Buckland, los servicios bibliotecarios, los usuarios de éstos, y la relación e interacción entre ambos, pueden considerarse como parte de un sistema. Considera que la biblioteca es esencialmente un sistema e indica que las actividades de interacción ocurren a través de la disposición y uso de los servicios, los 
cuales, sin embargo, no dejan de ser susceptibles a interferencias externas a la propia biblioteca. Una característica de los sistemas de este tipo (las bibliotecas) es la del control que éstos ejercen sobre su estructura, y la posibilidad de realizarlo sobre los impulsos que se reciben del exterior. A partir de esto, se constituyen los flujos de información (Buckland, 1988: 29-30).

En términos de las relaciones e interacciones que ocurren en la complejidad de la biblioteca (vista como sistema), Buckland observa que algunos libros son colocados en los estantes, y uno o algunos usuarios pueden utilizar uno o más de ellos. Empero, una observación más puntual revelaría que hay, en realidad, una infinidad de interacciones posibles. En virtud de las consideraciones de Buckland, lo que se vuelve importante es rescatar la existencia de lo que él llama una contradicción, en razón de que los sistemas en general se caracterizan por responder a los cambios, adaptarse a sus ambientes y mantener suficiente estabilidad para sobrevivir; estos aspectos, no obstante — según sus aseveraciones-, hacen que los servicios bibliotecarios se miren generalmente como débiles y sin capacidad de adaptación y estabilidad, pues la generación de servicios y el uso de la biblioteca es comúnmente endeble, incompleto o simplemente inexistente (Buckland, 1988: 31-33). Así, se considera que las bibliotecas pueden tener problemas serios pero realmente ninguna crisis dramática, lo que les permite sobrevivir.

\section{OBJETOS DE INFORMACIÓN Y DOCUMENTOS}

Para el tailandés Soraj Hongladarom, todo lo que existe, ha existido y existirá en el universo podrá ser concebido como objeto de información. Que cualquier cosa pueda ser intuida como un objeto de información significa que la información lo es prácticamente todo (Hongladarom, 2008: 180). Esto implica que la acepción de "objeto" se abre más allá del espectro de interacción de los seres humanos. Para Hjørland, "la información no es una cosa, pero todas las cosas sí pueden tener un carácter informativo [...] y estas cosas que se ven generalmente como importantes por sus potencialida- 
des informativas pueden calificarse como documentos" (Hjørland, 2000: 35). En esto se recuerda lo que sostuvieron Raber y Budd:

[...] la 'información' vista como un objeto teórico se encuentra en una posición poco envidiable. Se debe abarcar a la información, de alguna manera, como un objeto material, un efecto cognitivo individual, y una institución social (2003: 521).

Precisamente, para Hjørland, estos documentos deben ser organizados, recuperados y difundidos por archivos, bibliotecas, museos, y otros tipos de instituciones de memoria.

En las disquisiciones del diálogo transdisciplinario, la museología no tiene un mero papel contemplativo; su intervención en la última década ha sido más bien activa, ya que ha enriquecido la configuración de los conceptos "documento" y "objeto de información”, ampliándola a las piezas de museo. Michael Buckland establece que el museo ha sido el repositorio primordial de los objetos de información, y critica que la ciencia de la información haya recopilado principios y procedimientos de la documentación, la bibliotecología y la archivística, pero no así de la museología. Señala enfáticamente que:

Es probable que cualquier universidad establecida, por ejemplo, tenga una colección de rocas, un herbario de plantas conservadas, un museo de artefactos humanos, una variedad de huesos, fósiles y esqueletos, y muchas otras cosas más [...] Por supuesto, los objetos no son documentos en el sentido normal de "ser"; sin embargo, los textos pueden ser recursos de información, o sea, la información como cosa. Los objetos se recogen, almacenan, recuperan y se examinan como información, como la base para informarse. Entonces, habría que cuestionar la integridad del punto de vista de la ciencia de la información acerca de la información -o los sistemas de información-y de por qué no se extiende a los objetos, de la misma manera que con los documentos y los datos (Buckland, 1991: 354). 
De hecho, Kiersten Latham, de la Universidad Estatal de Kent, se basa en las postura de Michael Buckland (uno de los principales teóricos de la ciencia de la información) para aproximarse al objeto de museo y comprenderlo como un documento al cual los usuarios tienen acceso a través de un continuum de experiencia (entendida en el sentido estético de autores como Hume o Kant), como relación sujeto $\leftrightarrows$ objeto. Para ella, los objetos de museo, vistos como documentos, "pueden ser entendidos como actores y protagonistas de la transacción entre las personas y las cosas" (Latham, 2012: 67).

A la sombra de estas elucubraciones, quizá el concepto de "institución de memoria” en Hjørland (quien a su vez lo retoma de Roland Hjerppe) sea mucho más aplicable a la museología, principalmente porque en la biblioteca o el archivo es más factible que acaezca el fenómeno derridiano del anarchivo. Esto es mucho más factible de creer, principalmente, al cobijo del movimiento de la "nueva museología" que sobrevino hace veinte años encabezado por Pierre Mayrand, y que propugnó por una evolución de la mentalidad, concretada en la reflexión sobre el futuro de los museos como aquellas instituciones que fungirán como el "centro de la vida cultural del mañana” (Fernández, 2012: 19). Entonces, el objeto de museo era concebido como un objeto cultural, como una construcción procesal y cognitiva.

Buckland estableció que la información puede ser entendida bajo tres espectros: como proceso, conocimiento u objeto. En esta última dimensión, los objetos se consideran a partir de su carácter de ser "informativos":

Archivos, bibliotecas y oficinas están dominados por los textos: documentos, cartas, formularios, libros, publicaciones periódicas, manuscritos y archivos escritos de diversa índole, en papel, en microforma y en formato electrónico. El término "documento" se utiliza normalmente para referirse a textos o, más exactamente, a los objetos de texto que devengan. No parece haber ninguna razón para no extender el uso de "texto" y "documento" a imágenes, sonidos e, incluso, a la transmisión de algún tipo de comunicación, ya sea estética, inspiracional, instrumental, o lo que sea. En este sentido, 
una tabla de números puede ser considerada como texto, como un documento, o como datos (1991: 351 y 353).

Las diferencias entre las cualidades de los documentos a los que se abocan tanto la bibliotecología como la archivística son asequiblemente señalables: en la archivística son, casi siempre, documentos únicos y testimoniales; los documentos de la biblioteca, por su parte, pueden o no poseer esa cualidad, es decir, el bibliotecario está en el libre juego de dispersarlos y volverlos a relacionar de formas complejas no excluyentes bajo diferentes criterios (temática, semántica, obsolescencia, prestancia, circulación). Pero las diferencias entre el documento bibliotecológico y el objeto museológico son más pronunciadas. Como lo menciona Buckland, "algunos objetos informativos, como las personas y los edificios históricos, simplemente no se prestan a ser recogidos, almacenados y recuperados" (1991: 354) bajo el libre juego de la biblioteca.

No obstante, bajo la perspectiva de Tom Stonier (1991), el espacio no es el que determina el quehacer de la bibliotecología ni el de la ciencia de la información, por lo que la reubicación física de una colección no siempre es necesaria para la representación temática de estos documentos o el acceso continuo a ellos. Los objetos de museo, en sus ubicaciones existentes, pueden formar parte de una colección, y con esto se crea la sensación de una "colección virtual", en su sentido más estricto (producir un efecto), que se basa la relación con el usuario (espectador). En el caso de las imágenes, se pueden crear algunas descripciones o representaciones de ellas, ya sean películas, fotografías, ilustraciones, entre otras.

Como ya se mencionó, de la misma forma en que un libro o manuscrito son objetos físicos potencialmente capaces de informar a alguien, los objetos de museo también tienen un potencial informativo. Latham utiliza algunos criterios de Suzanne Briet y Michael Buckland para establecer qué es lo que determina a un objeto de museo como documento, y señala, principalmente, que lo que determina su estatus no es la materialidad, además de que detrás de su confección existe una intencionalidad, por lo que el objeto puede ser tratado como evidencia testimonial (Latham, 2012: 58). 
En contexto, Ania Hernández considera que, con el paso del dominio analógico al digital y con la amplitud pragmático-funcional, se está rebasando la función testimonial que tenían los archivos. Aunado a esto, apunta que:

Los archiveros no están solos, no son los únicos y mucho menos son huérfanos. No ya. Por primera vez en la historia, todas las disciplinas que se ocupan por separado de atender la información documentada, enfrentan, al unísono, "una forma unitaria de registro que resulta idónea para todas las formas de expresión humana". Por primera vez en la historia, un "progenitor común" se está presentado y propone disolver la crisis de identidad que afecta como "gueto intelectual", como trincheras del aislacionismo documental-funcional: la Filosofía de la Información. Por tanto, así como no se puede desconocer la naturaleza de los nuevos documentos, los riesgos y las ventajas que representan, lo cual ya hace tiempo es obvio, no se debe tampoco seguir tratando el análisis del fenómeno esencial (los registros de información y conocimiento) por separado, desde las remotas parcelas técnico-disciplinares de bibliotecarios, documentalistas, cientistas de la información, arquitectos o archiveros, excluyendo innecesariamente, desde estos presupuestos, importantes y comunes referentes teóricos y filosóficos (Hernández Quintana, 2006: 6).

Para esta autora cubana, la filosofía de la información es la que debe orquestar el puente de diálogo entre las disciplinas informacionales, ya que, al mismo tiempo que disipa el minimalismo particular de cada una, también refuerza la identidad de la comunidad epistémica de estas disciplinas. Floridi dice que una aproximación hacia las bases de la bibliotecología desde la filosofía de la información podría ayudar a trabajar ontológicamente su objeto de estudio, ya que es una teoría sustancial de la dinámica de la información, con un enfoque ético para su uso (Floridi, 2004: 659).

Sanjica Faletar y Boris Bosančić consideran que la forma en la que se concibe el constructo «información» dentro de la archivísti- 
ca, la bibliotecología y la museología es lo que determina, en realidad, las diferencias entre ellas. Ambos creen pertinente configurar un concepto común, pero no para construir una "gran ciencia de la información", sino para encontrar puntos que permitan la colaboración entre estas disciplinas. Ian Cornelius, por su parte, coincide en que se debe reconceptuar esta palabra, pero propone hacerlo con miras a fundamentar a la ciencia de la información. Él concita con los autores croatas en que cada una de las disciplinas informacionales (bibliotecología, documentación y archivística) concibe teóricamente la información de diferente manera, a partir de su propia dimensión pragmática; esto es, principalmente, lo que impide que la ciencia de la información pueda consolidarse:

La "información" que buscamos no es sólo algo "allá afuera" que tenemos que descubrir, es algo que sucede para que coincida con las condiciones de nuestra petición; es como saber cómo formular una pregunta que tendría la posibilidad de encontrar una respuesta [...] En cada caso, la comprensión de lo que se constituye como información, o "la información", está condicionada por la práctica social de la que les ha tocado ser partícipe, y por su propio estado (que podría ser dinámico) dentro de esa práctica social. Es el contexto de la práctica lo que hace que algo sea "información" (Cornelius, 2014: 190).

Para construir una disciplina que tenga cierta correspondencia en el mundo real - sostiene Cornelius-, se debe comenzar con la forma en la que el término "información" se utiliza en el mundo real. No obstante, esto tiene la atenuante de que cada disciplina conoce la realidad del mundo desde su propia perspectiva teórica, con lo cual no se avanza en esta cuestión. Lo cierto es que la palabra "información" se utiliza ampliamente en casi todos los campos y disciplinas, en su mayoría sin ningún significado profundo (salvo notables excepciones), pero de vez en cuando se usa como un término especializado asociado a una (de tantas) teorías de la información bajo parámetros de las prácticas de disciplinas particulares. En efecto, Rendón Rojas señala que: 
[...] existe una diversidad muy amplia de enfoques y propuestas sobre el objeto de estudio de la Ciencia de la Información debido a la transdisciplina, ya que como resultado de la evolución de varias ciencias (Bibliografía, Bibliotecología, Archivística, Documentación, entre otras) confluyen para dar origen a esa realidad compleja, sin que esas disciplinas desaparezcan completamente. Por otro lado, el enfoque desde el que se realiza la interpretación también influye en esa diversidad de posturas (2013: 39).

Tal como señala Simondon, al referirse a la información, ésta "no es jamás un término único, sino la significación que surge de una disparidad" (2009: 42).

\section{CONCLUSIONES}

El problema fundamental de las disciplinas informacionales radica en que, en este momento, parece haber poca suficiencia en el equilibrio de fuerzas centrífugas y centrípetas que puedan mantener al campo unido. Las personas del campo bibliotecológico (y sus estudiantes) no deben sólo especializarse en algún tópico de moda, sino que detrás de sus intereses debería prevalecer la preocupación por el campo en su conjunto. Deben verse a sí mismos dentro de la perspectiva del desarrollo histórico del campo. Si el campo se considera débil, si los estudiantes y profesores en el campo no pueden encontrar conocimiento útil dentro de la bibliotecología, entonces se tiende a utilizar los conocimientos de otros campos, lo que contribuye a aumentar el contenido deudor y, así, a las tendencias centrífugas y la erosión del terreno. 


\section{BIBLIOGRAFÍA}

Alfaro López, Héctor Guillermo. (2011). Estudios epistemológicos de bibliotecología. México: CUIB-UNAM.

Bacon, Francis. (1984). Novum organum. Madrid: Sarpe.

Boyd Rayward, Warden. (1996). "The history and historiography of information science: Some reflections". Information, Processing \& Management 32-1: 3-17.

Brier, Søren. (2006). "The foundation of library and information science in information science and semiotics". Libreas: Library Ideas: 4. http://www.ib.hu-berlin.de/ libreas/libreas_neu/ausgabe4/pdf/001bri.pdf.

Buckland, Michael Keeble. (1991). "Information as Thing". Journal of the American Society for Information Science, 42-5: 351-360.

Nueva York: Pergamon.

Buckland, Michael Keeble y Ziming Liu. (1998). "History of Information Science". En Trudi Bellardo Hahn y Michael Keeble Buckland, eds., Historical Studies in Information Science, 272-295. Nueva Jersey: Information Today / American Society for Information Science.

Burke, Colin. (2007). "History of information science". Annual Review of Information Science and Technology, 41-1: 3-53.

Cornelius, Ian V. (2014). "Epistemological challenges for information science: Constructing information". En Fidelia Ibekwe-SanJuan y Thomas M. Dousa, eds., Theories of information, communication and knowledge: A multidisciplinary approach, 181-203. Dordrecht: Springer.

Derrida, Jacques. (1997). Mal de archivo: Una impresión freudiana. Madrid: Trotta. 
Faletar, Sanjica y Boris Bosančić. "Can Archivists, Librarians, Museologists and Information Technology Specialists Join Hands to Do a Better Job?". Ponencia presentada en la 71 IFLA General Conference and Council, Oslo, 14 al 18 de agosto de 2005.

Fernández, Luis Alfonso. (2012). Nueva museología: Planteamientos y retos para el futuro. Madrid: Alianza.

Floridi, Luciano. (2004). "Library and Information Science as Applied Philosophy of Information: A Reappraisal". Library Trends, 52-3: 658-665.

Furner, Jonathan. (2015). "Information Science is Neither". Library Trends, 63-3: 362-377.

Hernández Quintana, Ania Rosa. (2006). "La filosofía de la información y la convergencia documental: Inserción de un paradigma teórico... no sólo en la archivística". Acimed: Revista Cubana de Información en Ciencias de la Salud, 14-3: 1-14.

Hjørland, Birger. (2000). "Documents, Memory Institutions and Information Science". Journal of Documentation, 56-1: 27-41.

Hongladarom, Soraj. (2008). "Floridi and Spinoza on Global Information Ethics". Ethics and Information Technology, 10-2, 3: 175-187.

Latham, Kiersten F. (2012). "Museum Object as Document: Using Buckland's Information Concepts to Understand Museum Experiences". Journal of Documentation, 681: $45-71$.

McCrank, Lawrence J. (2001). Historical Information Science: An Emerging Unidiscipline. Nueva Jersey: Information Today.

Nietzsche, Friedrich W. (1986). Asi hablaba Zaratustra: Un libro para todos y para nadie. México: Época.

Nitecki, Joseph Z. (1993). Metalibrarianship: A Model for Intellectual Foundations of Library Information Science. Nueva York: J. Z. Nitecki. 
Raber, Douglas y John M. Budd. (2003). "Information as Sign: Semiotics and Information Science". Journal of Documentation, 59-5: 507-522.

Rendón Rojas, Miguel Ángel. (2013). "Una epistemología dialéctica de la ciencia de la información: Entre Ariadna y Penélope". En VI Encontro Ibérico EDICIC 2013: Globalização, Ciência, Informação, Atas, 33-48. Portugal: Centro de Estudios de Tecnologías y Ciencias de la Comunicación-Universidad de Porto/ León: Universidad de Léon.

Ribeiro, Fernanda. (2006). "The Archival Training in the Post-custodial Era, in Accordance with a Scientific-informational Paradigm: The Portuguese Model". En The $2^{\text {nd }}$ Asia-Pacific Conference for Archival Educators and Trainers: The Archival Science and Archival Education in the Electronic Age, 165-176. París: International Council on Archives.

Silva, Armando Malheiro da y Fernanda Ribeiro. (2012). "Information Science and Philosophy of Information: Approaches and Differences". En Hilmi Demir, ed., Luciano Floridi's philosophy of technology: Critical reflections, 169-1987. Nueva York: Springer.

Simondon, Gilbert. (2009). La individuación a la luz de las nociones de forma y de información. Buenos Aires: La Cebra/Cactus.

Stonier, Tom et al. (1990). "Individual and domestic use of information”. En John Martyn, Peter Vickers y Mary Feeney, eds., Information UK 2000, 169-183. Londres: Bowker/Saur.

Stonier, Tom. (1991). "Towards a New Theory of Information”. Journal of Information Science, 17-5: 257-263.

Travis, Irene L. (2013). "Editor's Desktop". Bulletin of Association for Information Science and Technology, 39-4: 2. 


\title{
La era poscustodial: implicaciones en el campo de la ciencia de la información ${ }^{1}$
}

\author{
FERNANDA RIBEIRO \\ Facultad de Letras, CIC.Digital, Universidad de Porto
}

\section{LA VISIÓN TRADICIONAL: UN PARADIGMA EN CRISIS}

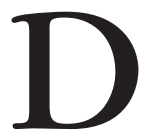

e la práctica empírica con orígenes milenarios asociada a las actividades profesionales en los archivos y bibliotecas, a la conciencia disciplinaria que emergió a mediados del siglo XIX con el surgimiento de la Archivología y la Biblioteconomía, se recorrió un largo camino que desembocó en el perfeccionamiento de los procedimientos y las técnicas, así como en la consagración de un área profesional que contaba con una identidad propia y una formación académica.

En el siglo XIX, las bibliotecas y los archivos nacionales eran las sedes por excelencia de la formación profesional de los bibliotecarios y archivistas; sin embargo, a la par de ellos, habían comenzado a surgir en casi todo Europa escuelas de modelo clásico que estaban destinadas a formar archivistas, paleógrafos y bibliotecarios eruditos. La Escuela Nacional de Chartes, establecida en París en

1 Traducción del original en portugués, "A era pós-custodial: implicaçoes no campo da Ciência da Informaçao”, por Miguel Ángel Rendón Rojas. 
1821, es el ejemplo más emblemático de ellas. ${ }^{2}$ De este modo, se intentaba formar al personal especializado que era necesario para trabajar con la documentación transferida a los archivos y las bibliotecas estatales, como resultado de las nacionalizaciones que tuvieron lugar después de la Revolución Francesa y los movimientos revolucionarios liberales similares que, bajo la influencia del modelo francés, se llevaron a cabo en varios países europeos.

Las concepciones ideológicas de la Ilustración que estuvieron en la base de los ideales del régimen liberal, asociadas con el desarrollo del positivismo y el historicismo a lo largo de la segunda mitad del ochocientos, se basaban en la idea de un Estado-nación y valoraban las fuentes documentales como instrumentos para legitimar jurídica y administrativamente la trasferencia del poder de la tierra a las manos de la burguesía, o para servir de apoyo en la escritura de la historia de la nación.

La creación de archivos, bibliotecas y museos públicos (del Estado), concebidos como instituciones destinadas a conservar la memoria nacional, configuró una nueva realidad que se fortaleció a lo largo del siglo XIX y consolidó en el siguiente, y fue una expresión de la visión paradigmática tradicional denominada como "custodial, historicista, patrimonialista y tecnicista". ${ }^{3}$

Las características de los servicios de información del siglo XIX, que brevemente se exponen a continuación, pone en evidencia los aspectos esenciales del paradigma tradicional:

2 Muy similares a la Escuela de Chartes estaban, por ejemplo, la Scuola del Grande Archivio en Nápoles (creada en 1811), el Bayerisches Archivschule München (1821), el Institut für Österreichische Geschichtesforschung en Viena (1854), la Escuela Diplomática de Madrid (1856), la Scuola di Paleografía y Diplomática en Florencia (1857). En Portugal, el Aula de Diplomática, creada por João Pedro Ribeiro en la Universidad de Coimbra en 1796, fue trasladada al Archivo de la Torre do Tombo en 1801 (decreto de 12 de febrero) porque asistir se hizo obligatorio para aquellos que quisieran convertirse en profesionales de los archivos.

3 Sobre la cuestión de paradigmas en la Ciencia de la Información, véase Silva y Ribeiro (2010). 
La formación profesional se obtenía en el marco de esos servicios y en sintonía con su misión y las actividades que desarrollaban. En el marco de ese paradigma vigente, no era, por lo tanto, de extrañar que el modelo de formación fuera histórico-erudito y centrado en cuestiones de custodia y elaboración de instrumentos destinados a apoyar el trabajo de los historiadores.

La formación académica tardó mucho tiempo en instituirse; no obstante, en el tercer cuarto del siglo XIX, ya habían surgido en Europa universidades que ofrecían la formación de archivistas (como las Universidades de Bolonia y Macerata en Italia) ${ }^{4}$ y de bibliotecarios (la Universidad de Columbia en Estados Unidos). 5 Sin embargo, estos casos fueron absolutamente excepcionales, pues la enseñanza de estas profesiones en la mayoría de los países era adquirida a través de cursos impartidos por las asociaciones profesionales de bibliotecarios o archiveros (Hayes, 1986). De hecho, antes de los años cuarenta del siglo XX, la formación de bibliotecarios, archivistas, museólogos y documentalistas no estaba presente en los medios universitarios de ninguna manera (Ribeiro, 2006). El hecho anterior es un síntoma evidente del carácter profesional de la formación, en detrimento de una fundamentación científica, académica y centrada en la investigación.

El modelo francés custodial, histórico-positivista y patrimonialista que se afianzó a lo largo del siglo XIX por el efecto de las condiciones socioeconómicas generadas durante la segunda y tercera olas de la industrialización; por el creciente aumento de la complejidad burocrática de las administraciones, y por los avances tecnológicos y científicos, ganó nuevos horizontes a partir de finales del ochocien-

4 En la Universidad de Bolonia, a finales del siglo XIX, el profesor Carlo Malagola dio el título de "Archivística" a una parte de sus lecciones; en la Facultad de Jurisprudencia de la Universidad de Macerata, el catedrático de Paleografía y Diplomática Lodovico Zdekauer escribió una obra titulada Nozioni archivistiche Generali, que constituye un apéndice a su Schema delle lezioni di paleografia e diplomática (Bucci, 1992: 25-28).

5 Por iniciativa de Melvil Dewey, en 1887 se inauguró un curso de formación para bibliotecarios en la School of Library Economy de la Universidad de Columbia. 
Cuadro 1.

Características de los servicios de información en el siglo XIX

\begin{tabular}{|l|l|}
\hline Naturaleza jurídica & \multicolumn{1}{|c|}{ Servicio público gratuito (nacional, regional, local/municipal). } \\
\hline Misión & $\begin{array}{l}\text { Guardar, tratar y difundir documentación de interés histórico } \\
\text { y cultural; instruir y educar. }\end{array}$ \\
\hline Denominación & Archivo o biblioteca. \\
\hline Tipo de acervo & $\begin{array}{l}\text { Documentos de carácter administrativo considerados de interés } \\
\text { histórico; libros, revistas y periódicos de índole cultural y/o científico. }\end{array}$ \\
\hline Personal & $\begin{array}{l}\text { Archivistas-paleógrafos, bibliotecarios eruditos, conservadores } \\
\text { y amanuenses. }\end{array}$ \\
\hline Actividades & $\begin{array}{l}\text { Organización de índices, inventarios, catálogos y repertorios; } \\
\text { clasificación y asignación de signaturas topográficas y resúmenes; } \\
\text { transcripción y publicación de documentos de documentos de } \\
\text { interés histórico. }\end{array}$ \\
\hline Tipo de acceso & $\begin{array}{l}\text { Consulta presencial en salas de lectura. En muchos casos, éstas } \\
\text { aún no estaban diferenciadas de los locales de depósito o búsqueda } \\
\text { en estantes o en los instrumentos de acceso (índices, inventarios, } \\
\text { catálogos...). }\end{array}$ \\
\hline Usuarios & $\begin{array}{l}\text { Historiadores, investigadores, intelectuales y eruditos o ciudadanos } \\
\text { del pueblo y la burguesía (lectura de ocio). }\end{array}$ \\
\hline
\end{tabular}

Fuente: elaboración propia.

tos, lo que se tradujo en una profundización de la vertiente técnica y una mayor autonomía de la Archivística y de la Biblioteconomía en relación con la Historia, por lo que se afirmaron como disciplinas de un saber independiente.

El énfasis en la vertiente técnica de la organización y el tratamiento de la información tuvo, naturalmente, efectos en lo que respecta a la formación profesional, que pasó a incorporar una serie de funciones no contempladas anteriormente, pero que en principio no configuró un cambio del paradigma dominante. De hecho, el modelo patrimonialista y custodial en esencia siguió vigente, apenas matizado por un tecnicismo que se impuso como necesario para hacer frente a las exigencias de los usuarios, deseosos de consultar las masas documentales custodiadas por los servicios públicos (se debe recordar que la Revolución Francesa también fue respon- 
sable de la promulgación de la ley que establece el derecho de acceso a la información de todos los ciudadanos).

El lugar de la técnica pasó a ser fundamental y suscitó preocupaciones en cuanto al acceso a la información, la normalización descriptiva, los instrumentos de búsqueda y la formación profesional. El incremento de la importancia de la técnica se acentuó de forma notoria a partir del momento en que la revolución tecnológica, a mediados del siglo XX, planteó nuevos desafíos y evidenció las limitaciones de la formación impartida para responder cabalmente los problemas que la Era de la Información planteaba.

Si los modelos de formación profesional son un elemento clave para fundamentar la caracterización paradigmática, la investigación no es menos importante, aunque en el paradigma custodial y tecnicista sea más apropiado hablar de la ausencia de investigación como uno de sus rasgos dominantes. Sobre este punto, son esclarecedoras las palabras de Emilio Delgado López-Cózar cuando afirma que "en el desarrollo de la ByD (Biblioteconomía y Documentación) la teoría siguió a la práctica, no la dirigió ni la guió. La investigación en particular y la ByD como disciplina en general, hunden sus raíces en la práctica bibliotecaria" (2002: 24). Al no tener una fundamentación teórico-metodológica susceptible de respaldar el trabajo de investigación (entendido como una investigación aplicada), no es posible conceder a la actividad práctica y profesional un estatus de actividad de investigación.

La actividad profesional es justamente el tercer eje que enunciaremos para fundamentar la existencia del paradigma tradicional. En las áreas de documentación e información, la práctica profesional dominó (y aún lo hace) las actividades desarrolladas. Es sintomático que en varios países (Estados Unidos y Reino Unido, por ejemplo) las asociaciones profesionales tengan el poder de producir guías para el desarrollo de los currículos de las universidades. El trabajo de los bibliotecarios, archivistas y documentalistas tradicionalmente guardadores de documentos y mediadores en los préstamos de servicios a usuarios que buscan información, se ha basado en un conjunto de orientaciones técnico-normativas destinadas más a la organización y representación de la información para su acceso, que 
al conocimiento de los contextos generadores de esa misma información y su comunicación de acuerdo con las necesidades y el comportamiento informacional de los usuarios. El hecho de que el objeto de estudio y trabajo sea el "documento" (entidad física, estática y materialmente separada del productor que originó la información contenida en él) hace que el análisis y la representación de su contenido sea algo confinado a la aplicación de procedimientos normativos muy poco claros ante las teorías interpretativas y los métodos de investigación cualitativos y cuantitativos que deben aplicarse en el campo de las Ciencias Sociales y Humanas.

La evolución social, económica, cultural y sobre todo tecnológica que tuvieron lugar a partir de la segunda mitad del siglo XX, acentuaron la crisis que el paradigma tradicional ya manifestaba, cuestionaron sus fundamentos esenciales y generaron las condiciones para que comenzara a surgir y afirmarse de manera irreversible un nuevo paradigma en el campo de la información. La aparición de la nueva perspectiva que comenzó a percibirse desde mediados del siglo XX y tiene sus raíces en la visión precursora de Paul Otlet y Henri La Fontaine, surgida a finales del ochocientos y que más tarde se convirtió en la organización mundial de referencia Mundaneum, así como en la defensa de una nueva área profesional: la Documentación. ${ }^{6}$

\section{EL PARADIGMA POSCUSTODIAL: UNA VISIÓN EMERGENTE}

A finales de la década de 1950, los bibliotecarios y documentalistas especializados comenzaron a buscar su propia identidad al desempeñar funciones en centros de documentación y de información o en bibliotecas especializadas, y se dedicaron profesional y académicamente a fundamentar la Ciencia de la Información; inclusive, disputaron algo de terreno a los profesionales del área de la informática. En el ámbito de los archivos, sin embargo, fue necesario que

6 Sobre la actividad de Paul Otlet y Henri La Fontaine, ver W. Boyd Rayward (1997) e Isabelle Rieusset-Lemarié (1997). 
llegara la década de los ochenta para que, gracias a algunas cuestiones concretas que se asumieron como prioridades - la normalización descriptiva y la preservación de los documentos electrónicos son dos casos ejemplares- se empezara a cuestionar el paradigma tradicional.

La simbiosis entre información y tecnología digital puso en tela de juicio la noción estática de "documento" (generalmente identificado como un mensaje registrado en un soporte de papel), y lo propuso como un concepto operativo y un objeto de estudio, al mismo tiempo que marcó la entrada de los archivos, las bibliotecas y los museos a la era poscustodial.

Este cambio de paradigma exige, naturalmente, una formación profesional acorde (Ribeiro, 2007). ¿Será que la formación recibida actualmente por archivistas, bibliotecarios y documentalistas los prepara y capacita para responder a los principales retos planteados por las Tecnologías de la Información y Comunicación englobadas en el concepto general y sociológico de la sociedad de la información?

El nuevo paradigma poscustodial y científico-informacional (Silva y Ribeiro, 2010) implica un profundo cambio de perspectiva; cambia el objeto de estudio y de trabajo ("documento" por "información”); reclama metodologías de investigación adecuadas al estudio de un fenómeno humano y social (la información) que no difieren de las utilizadas por las ciencias sociales en general, y concibe la Archivística y a la Biblioteconomía no como técnicas con características específicas propias, sino como disciplinas aplicadas del área de la Ciencia de la Información.

Una definición estricta de "información" es esencial para postularla como objeto de estudio e imprescindible para prever aspectos requeridos de la formación profesional al trabajar en esta área. De esta manera, si definimos la información como:

un conjunto estructurado de representaciones mentales codificadas (símbolos significativos) socialmente contextualizadas y plausibles de ser registradas en cualquier soporte material (papel, película, cinta magnética, disco compacto, etc.), y por tanto de ser 
comunicadas de forma asíncrona y multidireccionada (Silva y Ribeiro, 2002: 37).

Estamos obligados a revisar críticamente la noción de "documento" y a delimitar un área científica que tome la información como objeto.

Las múltiples consecuencias teórico-prácticas de la definición propuesta y de la crítica de la noción de documento afectan directamente a las profesiones de los archivistas y los bibliotecarios, que no pueden seguir siendo los que guardan, conservan y organizan documentos, sino que tienen que asumirse como gestores de la información producida y utilizada en cualquier contexto orgánico. Ser gestor de información se convierte en un reto difícil pero apasionante, pues apremia repensar toda una herencia empírica milenaria y cuestionar el sentido de la profesión ya no en un marco de actividades de salvaguarda del patrimonio, sino en una perspectiva de acceso y conservación de la información, elemento esencial de la memoria identitaria de los organismos productores.

Además de eso, también le compete al gestor de información de la era poscustodial el ejercicio de contribuir a rediseñar las fronteras de una disciplina que hace de la información no sólo su materia prima, sino su objeto central de estudio y de investigación.

Al ser empujados, bajo el impulso de la revolución tecnológica de la información, hacia un mismo objeto y metodologías comunes, el archivista, el bibliotecario, el documentalista y el especialista en informática de la gestión tienden a fundirse en un nuevo profesional que sintetiza las diversas competencias adscritas a todas ellas y se asume como un especialista que estructura el flujo informacional que fluye dentro de las organizaciones y alimenta el funcionamiento y la capacidad para tomar decisiones de las mismas.

El nuevo paradigma poscustodial, científico e informacional se puede caracterizar de la siguiente manera por sus rasgos esenciales:

- Valorización de la información (fenómeno/proceso humano y social) con el reconocimiento de que en ella misma y no en el soporte (material externo al sujeto) reside su propia 
historicidad (orgánico-contextual) y su riqueza patrimonial/ cultural.

- Afirmación del incesante y natural dinamismo informacional frente a la inmovilidad documental, donde el primero se convierte en el trinomio creación-selección-acceso/uso y el segundo en la antinomia artificial "vida" efímera-permanencia/conservación.

- Imposibilidad de mantener la separación documental de la información por el espacio institucional y tecnológico donde se conserva (servicio de archivo, servicio de biblioteca y sistema informático/software de computador), ya que este criterio es superficial y no tiene en cuenta el contexto dinámico de producción (organicidad), retención/memoria y uso/consumo (funcionalidad).

- Necesidad de conocer (indagar, comprender y explicar) la información social a través de modelos teórico-científicos cada vez más exigentes y eficaces en lugar del universo rudimentario y cerrado de la práctica informacional empírica compuesta por un conjunto uniforme y acrítico de modos/ reglas de hacer, de procedimientos sólo aparentemente "asépticos" u "objetivos" de creación, clasificación, ordenación y recuperación.

- Sustitución de la lógica instrumental evidente en las expresiones "gestión de documentos" y "gestión de la información" por la lógica científico-comprensiva de información en la gestión, es decir, la información social está implicada en el proceso de gestión de cualquier entidad organizacional y, por lo tanto, las prácticas y los procedimientos informacionales atraviesan y se articulan con las concepciones y prácticas de los gestores y actores, así como con la estructura y cultura organizacionales, por lo que el archivista e incluso el documentalista deben, en lugar de establecer o imponer reglas operativas, comprender el sentido de tales prácticas, como se exige, por ejemplo, a un sociólogo de las organizaciones, y presentar dentro de ciertos modelos teóricos las soluciones retro o prospectivas más adecuadas (Silva y Ribeiro, 2011). 
Confrontadas con este paradigma emergente, las referidas "prácticas empíricas de organización” (archivística y biblioteconómica), en palabras de Le Coadic (1997: 517), no pueden subsistir artificialmente autonomizadas y disfrazadas de "científicas" por mucho más tiempo, por lo que deben ser reenmarcadas epistemológicamente de un modo serio y consistente que no pase ya por la anacrónica, reductora y frágil "teoría" de la documentación, sino por una profundización crítica del debate sobre la naturaleza y evolución de la Ciencia de la Información, asumida en singular y no en un plural fragmentado y dividido que, literalmente, excluye de ese campo científico un modelo unitario y transdisciplinar. En el marco de este nuevo paradigma, los ejes de enseñanza, investigación y práctica profesional ganan nuevos contornos y diferentes modos de acercamiento.

Los temas de la enseñanza y el modelo formativo ajustado al nuevo paradigma ya han sido discutidos en varios textos (Silva y Ribeiro, 2001 y 2004; Ribeiro, 2006 y 2007), por lo que aquí nos limitamos a enunciar algunos de sus presupuestos fundamentales. Los marcos socioeconómico, tecnológico, político-institucional y cultural de la segunda mitad del siglo XX sufrieron tantos y tan rápidos cambios, que el área de la Documentación no podía quedar inmune. Por lo que cabe preguntarse, ¿cuál es la formación adecuada para los profesionales de la información y la documentación?

Parece evidente que es necesario distinguir dos modalidades de intervención teórico-práctica: una de naturaleza esencialmente técnica - una formación a nivel medio con un perfil técnico-profesional, que pueda ser proporcionado por escuelas técnico-profesionales o escuelas de enseñanza secundaria-, y otra de un nivel más comprensivo y explicativo, de un saber fundado en el estudio y la investigación mono, inter y multidisciplinar, que tome las ciencias sociales como eje central y punto de derivación para el cruce con otras disciplinas científicas. Este segundo tipo de formación debe ser impartida por universidades e institutos politécnicos.

La formación de técnicos profesionales, cuyas aptitudes y competencias hoy en día no pueden carecer de un adecuado entrenamiento informático, responde a exigencias prácticas que la gestión de la información (en el sentido amplio y transversal que involu- 
cran todos los sectores de la actividad humana y social) sitúa y situará cada vez más en una perspectiva esencialmente operativa. La educación superior (iniciada en la licenciatura y que prosigue en la maestría y el doctorado) deberá seguir un diseño curricular que prevea anular las separaciones artificiales que se producen en la formación tradicional a través de las "ramas" de archivo, biblioteca y documentación donde, por ejemplo, las operaciones de representación de la información (como la descripción o la clasificación) son distribuidas en diferentes disciplinas si se trata de archivos o bibliotecas. Esta perspectiva unitaria también intenta realizar una síntesis con el área de los llamados Sistemas (tecnológicos) de la Información (SI), que han venido experimentando una progresiva autonomía frente a la Informática y Computación tradicionales, y que tienen como campo de trabajo y profesionalización a las organizaciones en general.

El modelo que perfilamos se basa en los presupuestos teóricometodológicos que sustentan la Ciencia de la Información tal como han sido pensados y desarrollados en la Universidad de Porto (Silva y Ribeiro, 2002). Este modelo congrega en el núcleo del área científica - la Ciencia de la Información- un conjunto de disciplinas que, por un lado, aseguran un componente teórico y metodológico y, por otro, contemplan las vertientes aplicadas de esa área del conocimiento con sus especificidades particulares. El "núcleo duro" del currículo debe estar necesariamente abierto a la interdisciplinariedad, y establecer relaciones más o menos estrechas con otros campos. Dichas relaciones deberán ser abordadas a través de la presencia de diversas disciplinas, algunas de carácter obligatorio y otras opcionales, pero siempre complementando las materias del área científica nuclear.

El eje de la investigación tampoco puede ser disgregado de la fundamentación teórica (preferentemente de la teoría sistémica) ni del enfoque metodológico (método cuadripolar) (Silva y Ribeiro, 2002), lo que desde luego es una diferencia esencial en comparación con el paradigma tradicional en el que la teoría y el método están ausentes y/o se confunden con (y se agotan en) actividades técnicas. Investigar pasa a significar conocer, analizar, interpretar y 
explicar y ya no sólo es describir recurriendo a normas acríticamente aplicadas. Investigar es, en Ciencia de la Información, una actividad esencialmente aplicada y, como tal, se traduce en una práctica profesional con nuevas formas de intervención. Veamos cómo se puede concretar en la práctica este nuevo enfoque y cuáles son las características fundamentales que lo identifican:

- Elegir la información (a la luz de la teoría sistémica) como objeto de trabajo y estudio obliga a observar un Documento (unidad física que se clasifica, describe, ordena, y a la cual le es atribuida una signatura para su localización posterior) de una manera completamente diferente a como hasta ahora se ha hecho. Percibir la información implica, antes que nada, conocer el contexto de su producción, lo que representa un proceso anterior a su registro material en un soporte físico. Asimismo, también implica conocer el uso que le fue o es dado a esa información; es decir, quiénes son sus usuarios, con qué fin la usan, cómo la buscan, con qué frecuencia, etc. Pensar sistémicamente la información significa entonces algo más que estructurar servicios (bibliotecas, archivos...) dentro de las organizaciones, es importante percibir holísticamente los contextos de su producción y uso, en una visión integrada que no separe (ni genere) artificialmente información de archivo, de biblioteca o digital sin análisis, sino en una visión integrada y como un sistema con todos sus componentes.

- Comprender el trabajo del profesional de la información como un proceso de investigación que pretende conocer y representar con rigor la realidad informacional bajo análisis tiene igualmente varias consecuencias, ya que el profesional deja de actuar como un simple técnico que aplica normas y procedimientos uniformes para la producción de instrumentos más o menos estándar que posibilitan el acceso a la información, y pasa a tomar el papel del científico de la información que presenta resultados validados por una metodología científica, sin dejar de cuestionar (problematizar, formular hipótesis) 
su propia actuación, siempre en referencia a paradigmas y teorías que están en permanente validación (o revisión).

- Aplicar el método de investigación cuadripolar pone el énfasis en el análisis orgánico-funcional, requisito indispensable para alcanzar un conocimiento riguroso de la estructura del sistema y de las funciones y competencias de los diversos sectores que conforman esa estructura, pues sólo así es posible caracterizar con rigor el contexto de producción de la realidad informacional que se analiza.

- Tratar de conocer las relaciones sistémicas internas y externas, así como su reflejo en la producción informacional, exige realizar una investigación para identificar eventuales subsistemas de información o percibir las relaciones entre, por ejemplo, los diversos nodos que forman entre sí un supersistema de información.

- Analizar el componente funcional del sistema conduce a que determinadas operaciones tengan que ser implementadas como medidas "profilácticas" regulares destinadas a optimizar el funcionamiento del propio sistema de información; entre ellas, por ejemplo, se tienen la evaluación retro y prospectiva, operación fundamental que permite detectar redundancias y "desperdicios" informacionales.

- Comprender las operaciones técnicas de descripción, clasificación e indización como el resultado natural de todo el proceso del conocimiento que previamente tuvo lugar y no como el objetivo reduccionista de proporcionar el acceso por el acceso a la información también es fundamental para que los instrumentos de búsqueda elaborados (catálogos, índices, inventarios, bases de datos...) garanticen una representación adecuada de la realidad informacional que es el objeto de análisis. 
En suma, pensar la Ciencia de la Información a la luz del nuevo paradigma en la era poscustodial implica una visión integrada donde no tiene sentido organizar servicios de información con una finalidad meramente instrumental que separe artificialmente los diversos componentes de un todo, y sin concebir sistemas de información en el que el componente funcional se concrete en la estructuración de servicios que agreguen todos los componentes informacionales. Por el contrario, la información es generada en un determinado contexto organizacional por los diferentes agentes que actúan en ese mismo contexto, sea en el área administrativa, técnica o científica.

\section{BiBLIOGRAFÍA}

Bucci, Oddo. (1992). "Il Processo evolutivo dell'archivistica e il suo insegnamento nell'Università di Macerata". En Conferenza Internazionale, L'Archivistica alle soglie del 2000, 17-43. Macerata: Universidad de Macerata.

Le Coadic, Yves-François. (1997). "Science de l'information". En Serge Cacaly, Dictionnaire encyclopédique de l'information et de la documentation, 516-523. París: Nathan.

Delgado López-Cózar, Emílio. (2002). La Investigación en biblioteconomía y documentación. Gijón: Ediciones Trea.

Hayes, Robert M. (1986). "Information Science education". En ALA World Encyclopedia of Library and Information Services. Chicago: American Library Association.

Malheiro da Silva, Armando y Fernanda Ribeiro. (2011). Paradigmas, serviços e mediações em Ciência da Informação. Recife: Néctar.

. (2010). Recursos de informação: serviços e utilizadores. Lisboa: Universidade Aberta.

- . (2004). "Formação, perfil e competências do profissional da Informação". En $8^{\circ}$ Congresso Nacional 
de Bibliotecários, Arquivistas e Documentalistas. Nas encruzilhadas da Informação e da Cultura: (re)inventar a profissão. Lisboa: BAD. CD-ROM.

. (2002). Das "Ciências" Documentais à Ciência da Informação: ensaio epistemológico para um novo modelo curricular. Porto: Edições Afrontamento.

. (2001). "A Mudança de paradigma na formação BAD: um modelo formativo para a Ciência da Informação". En $7^{\circ}$ Congresso Nacional de Bbibliotecários, Arquivistas e Documentalistas- Informação: o desafio do futuro. Actas do congresso. Lisboa: BAD. CD-ROM.

Rayward, W. Boyd. (1997). "The Origins of Information Science and the International Institute of Bibliography / International Federation for Information and Documentation (FID)". Journal of the American Society for Information Science. 48-4: 289-300.

Ribeiro, Fernanda. (2007). "An Integrated Perspective for Professional Education in Libraries, Archives and Museums: a New Paradigm, a New Training Model". Journal of Education for Library and Information Science. Chicago 48-2: 116-124.

- . (2006). "Um modelo formativo em Ciência da Informação, de feição europeia e adequado a Bolonha: o caso da Universidade do Porto". Cadernos BAD. Lisboa 1: 16-27.

Rieusset-Lemarié, Isabelle. (1997). "P. Otlet's Mundaneum and the International Perspective in the History of Documentation and Information Science". Journal of the American Society for Information Science. Nueva York 48-4: 301-309. 


\title{
La permanente defensa de la archivística por su autonomía
}

\author{
Silvana Elisa Cruz Domínguez \\ Universidad Autónoma del Estado de México
}

Decir que una ciencia defiende su autonomía significa que una ciencia defiende su título a ser ciencia. CARLOS COSSÍO

\section{INTRODUCCIÓN}

\begin{abstract}
A partir de la publicación del manual holandés en 1898, la Archivística, una disciplina que consistía en un conjunto de - 1 pácticas empíricas, se autoproclamó como una ciencia autónoma. Desde entonces y hasta hoy -en especial en el sector más tradicional-, perdura una postura defensiva en torno a la autonomía de la disciplina. El temor a perder su identidad le ha conducido a una férrea negación de establecer diálogos con otras áreas del conocimiento. Sin embargo, como lo expresaron desde hace más de tres décadas Couture y Rousseau, "la autonomía no significa aislamiento" (1988: 75). En efecto, desde sus orígenes y hasta ahora, la práctica y teoría archivística han estado vinculadas a otras disciplinas, como veremos a continuación, en una periodización que responde a la clásica segmentación histórica y a ciertos eventos relevantes que permearon la disciplina.
\end{abstract}




\section{PRIMERA ETAPA: ARCHIVÍSTICA EMPÍRICA Y ADMINISTRACIÓN}

Los archivos existen desde que aparecieron las primeras culturas escritas. Los indicios señalan que se crearon en la antigua Mesopotamia con el fin de apoyar la tarea gubernativa, la administración y el comercio. Servían de apoyo para la recaudación de impuestos, el cobro de los peajes y realizar transacciones sobre propiedades; además, fueron conservados para establecer derechos, privilegios y linajes reales. Los egipcios realizaron censos en los territorios conquistados con el propósito de conocer el total de mano de obra disponible y la cantidad de individuos con los que contarían para el servicio militar. (Gilliland y White, 2009). En Grecia, los archivos eran similares a los egipcios. Los escasos documentos griegos que se han preservado están hechos en tablillas de arcilla, madera y pergamino, cuya temática es económica y administrativa. De la cultura griega proviene el vocablo archeion, cuya traducción latinizada corresponde a archivum. Concepción Mendo Carmona (1995: 113132) sugiere que ya desde esa época, se aplicaba el principio de procedencia porque cada magistratura tenía su propio archeion, donde se conservaban los documentos oficiales.

Por su parte, los romanos desarrollaron un sistema de archivos que se convirtió en una parte integral de la administración del derecho romano, el cual fue exportado hacia todo el extenso territorio del imperio. Los documentos producidos por cada una de las oficinas se depositaron en distintas galerías del tabularium. Fue en esta época cuando apareció el concepto de "archivo público", sólo que entonces estaba reservado para unos cuantos y era principalmente un instrumento al servicio del poder. A partir de esa época, los archivos quedaron vinculados con los procedimientos y las formas jurídicas del derecho romano.

La Edad Media significó un retroceso en la administración pública, pues de la concepción del Estado como esfera pública, se pasó a la del Estado como propiedad de quien ejercía el gobierno; por lo tanto, la facultad de crear archivos pasó a manos de los emperadores, reyes, señores y pontífices. El descenso del derecho romano 
provocó la pérdida de la eficacia de los documentos escritos como base para la administración gubernamental; ahora, importaban los títulos de propiedad, que eran resguardados en catedrales y monasterios. La monarquía y los señores feudales precisaban de su patrimonio para permanecer en el poder, y sus títulos eran conservados como verdaderas joyas. De esta época data también una nueva relación de la práctica archivística, esta vez, con la Bibliotecología, pues los archivos y libros de los señores se conservaban unidos, además de que se utilizaba el mismo método de ordenación para ambos (Mendo Carmona, 1995: 113-132). Durante la Edad Media, los cancilleres, notarios y escribanos ejercieron el papel de archivistas; también los cancilleres de las curias eclesiásticas y casas señoriales cumplieron tareas similares.

Para el siglo XII, se recuperaron los procedimientos y formularios documentales del derecho romano y, con ello, el método archivístico por excelencia que posteriormente fue llamado "principio de procedencia". En efecto, la burocracia y estructura de las organizaciones siempre han representado una configuración lógica y un esquema de organización natural para los archivos, bajo los cuales los funcionarios archivistas conservaron los documentos de acuerdo con su origen por cientos de años. En este periodo, con el surgimiento de la autonomía municipal, apareció una de las más grandes aportaciones de la época medieval a la práctica archivística: el registro, que eran los libros donde se anotaba una síntesis de cada uno de los documentos de las cancillerías. Los inventarios compilados entre ese tiempo y hasta el siglo XV en las ciudades-estado italianas tenían por objeto proporcionar evidencia de la existencia de los documentos, los cuales debían conocer los consejos de la ciudad; su objetivo secundario fue hacer un balance del material conservado. Durante el siglo XIII en el reino de Nápoles, la compilación de inventarios se convirtió en uno de los deberes regulados del archivista. El propósito de esta descripción fue por un lado jurídica: proporcionar evidencia de la existencia de los documentos y, por el otro, administrativa: mantener el control sobre los bienes y facilitar la recuperación de los documentos necesarios para llevar a cabo transacciones económicas. Este con- 
cepto de la descripción continuó durante la época de las monarquías absolutas, cuando los archivos fueron secretos e inaccesibles (Duranti, 1993: 47-54).

En cambio, en el reino catalano-aragonés, aunque es posible identificar un archivo en el año 1180, no existen vestigios de descripción; ésta se realizó hasta 1318, cuando el rey Jaime I fundó en su palacio de Barcelona el Archivo Real. El interés por el archivo residía también en el aspecto jurídico administrativo, ya que el monarca ordenaba a las cortes consultar en el archivo los antecedentes de las cuestiones que interesaban para el fomento de las rentas y atribuciones reales. En 1384, se dictaron las primeras ordenanzas para el archivo; en ellas se estipulaba que se debía velar por la preservación de los documentos más importantes, los cuales eran depositados en armarios o cofres con tres o hasta cinco llaves, práctica que continuó durante la Edad Moderna (Alberch Fugueras, 2003: 33-34).

\section{SEGUNDA ETAPA: DOCTRINA JURÍDICA}

\section{AL SERVICIO DE LA ADMINISTRACIÓN}

El periodo que va del siglo XVI al XVIII fue llamado por RobertHenri Bautier como el de "los archivos como arsenal de la autoridad". Durante esta etapa, caracterizada por las monarquías absolutas, es cuando surgieron los archivos de Estado, lugares en los que se concentraron todos los archivos de las coronas europeas que hasta entonces se habían atesorado en manos de cancilleres, secretarios y demás funcionarios reales. Así, se formaron los archivos de Viena, de Indias, Francia e Inglaterra, entre otras monarquías que crearon los archivos de Estado para coadyuvar a mantener una administración más eficaz. A esta etapa corresponden también los archivos pontificios, que fueron reunidos en 1611 en el Archivo Secreto del Vaticano.

Es también el momento en el que aparecieron las primeras instrucciones para el arreglo de los archivos. La experiencia y los conocimientos acumulados durante el largo tiempo de la práctica 
empírica encontraron su expresión gráfica en diversos manuales y reglamentos. No obstante, fueron esfuerzos aislados, no sistematizados, en los que no se logró un corpus teórico (Vivas Moreno, 2004: 76-96). Por ejemplo, en 1571, Jakob von Rammingen publicó dos tratados en los que ponderaba la existencia de los archivos adecuadamente clasificados como un instrumento del gobierno. En 1632, el erudito veneciano Baldassarre Bonifacio señaló en su De Archivis que el archivo es algo "divino", y que los académicos le nombran "el alma del mundo", y sostuvo que los archivos desordenados no sirven de nada. En el capítulo IX, recomienda dividir los archivos primero por ubicaciones, después por asuntos y, finalmente, de manera cronológica (Brichford, 1989: 54-70).

En la península ibérica, los indicios señalan que el Archivo de la Corona de Aragón ya existía en el Siglo IX; sin embargo, la consolidación de la monarquía y sus archivos fue un poco más tardía. El proyecto del archivo de la Corona de Castilla data de fines del siglo XV, cuando los Reyes Católicos ordenaron la concentración de sus expedientes en la Chancillería de Valladolid; sin embargo, la corte del imperio era itinerante y los archivos viajaban junto con el monarca. Fue su hijo, el emperador Carlos V, quien trasladó los documentos de Castilla a Valladolid. Felipe II decidió asentar la corte en Madrid y abandonar la constante migración que la caracterizaba. En 1540, fundó el archivo de Simancas debido a que le interesaba conservar, además de los instrumentos que amparaban sus títulos y privilegios, los documentos que trataban sobre las acciones de gobierno que se emprendían para sus súbditos; por ello, uno de sus biógrafos decía que Felipe II "por medio de los papeles meneaba el mundo desde su real asiento" (Rodríguez de Diego, 2005: 297-304).

En el Archivo de Simancas, se reunieron los documentos de todos los órganos de gobierno, fue el primer archivo de Estado; en 1588, se dictaron las Instrucciones para el Gobierno del Archi$v o$, en las que se estipulaban los procedimientos para recoger los documentos, conservarlos y describirlos. De acuerdo con Rodríguez de Diego, Felipe II consideraba al archivo como un "medio de poder y dominio" reservado exclusivamente para él, pues nadie 
podía admitirse en el archivo ni obtener la copia de algún documento sin la anuencia real. Durante esta etapa, los archivos fueron inaccesibles para todos a excepción de aquellos que obtuviesen permiso de los monarcas.

En 1790, Carlos IV de España dictó las ordenanzas para el manejo del recién creado Archivo General de Indias. El propósito del Archivo fue reunir todos los documentos relativos a la administración española en América y Filipinas que hasta entonces se habían concentrado en el Archivo General de Simancas, el cual para este tiempo se encontraba saturado. Se dispuso que todos los documentos relativos al gobierno de Indias, tanto los actuales como los que se hicieran en el futuro, se reunieran en el Archivo de Indias de acuerdo con la institución de la que procedieran.

El Archivo se convirtió en la base de la organización administrativa del Estado; en consecuencia, en Europa Occidental y las colonias del Nuevo Mundo, el Archivo fue utilizado como un elemento esencial en las actividades de gobierno. Dado que la base de la administración fueron los archivos, los estudiosos han llamado a esta fase de la Archivística "doctrina jurídica al servicio de la administración", lo que muestra la estrecha relación entre la Archivística y el Derecho.

Otro acontecimiento importante de la Época Moderna fue la aparición del tratado De re diplomatica, del erudito maurista Jean Mabillon en 1681, el cual dio origen a una nueva y fructífera relación de la Archivística, esta vez con la diplomática, relación que permeó profundamente la disciplina y la encaminó hacia los principios que la llevaron a proclamar su estatuto científico. En efecto, el método diplomático para autentificar los documentos implica una serie de estudios específicos y la comparación de documentos emitidos por una misma dependencia administrativa o persona; es decir, es preciso analizar la procedencia de los documentos a estudiar. De esta manera, empezaron a gestarse los principios de procedencia y de orden original (Brichford, 1982: 67-101).

Como se puede observar, desde sus inicios y hasta la Edad Moderna, los archivos fueron conservados para el uso administrativo de sus creadores y para comprobar privilegios y derechos reales. 
El propósito de su preservación no era otorgar material de consulta a los investigadores, sino servir de arsenal de información para la administración. Por lo tanto, durante esta etapa, el ejercicio archivístico estaba ligado fundamentalmente al Derecho, la Administración, la Bibliotecología y la Diplomática. La práctica archivística consistía en sencillas operaciones de archivado, copiado, elaboración de pequeñas guías para señalar los documentos existentes y su colocación en los gabinetes.

\section{TERCERA ETAPA: ARCHIVÍSTICA E HISTORIA}

Desde el siglo XV, los Archivos también fueron visualizados como instituciones culturales a las que se acudía no sólo para amparar los derechos patrimoniales, sino también para que los eruditos al servicio de los monarcas realizaran investigaciones históricas que pusieran énfasis en las glorias de sus antecesores. La mayoría de las instituciones que tenían una larga historia, así como los reyes y señores, eclesiásticos y laicos, deseaban aumentar el valor de sus archivos, por lo tanto querían hacerlos accesibles a los estudiosos, lo que motivó que algunos historiadores fuesen contratados como archivistas con el objeto de producir documentos descriptivos que, además de llevar a cabo sus fines tradicionales, pudieran orientar los investigadores hacia los documentos más importantes para la Historia (Duranti, 1993: 48).

Por otra parte, la Revolución Francesa trajo consigo un fuerte movimiento nacionalista que impregnó la mayor parte de Europa; tal chovinismo propició la creación de los archivos nacionales, lo que significó un gran avance para la archivística, pero a causa de ello se destruyó un gran número de archivos feudales que los revolucionarios llamaron "basura medieval" ya que amparaba los derechos de los señores del antiguo régimen. Otro retroceso tuvo lugar cuando se nombró a Pierre Claude François Daunou, quien había trabajado en bibliotecas como archivista del imperio napoleónico. Daunou aplicó la metodología bibliotecaria en la clasificación archivística. Este tipo de organización respondía a los métodos cla- 
sificatorios de la época y facilitaba los estudios históricos; en ocasiones, se clasificaba por periodos cronológicos, pero principalmente por tema, en armonía con la mentalidad racionalista y clasificatoria del siglo XVIII, lo que refleja el espíritu de la Ilustración y la enciclopedia. Además, el nacionalismo obligó a la búsqueda de documentos históricos que dieran los fundamentos de identidad a las flamantes naciones (Duranti, 1993: 48).

Los dos primeros directores de los archivos nacionales franceses mezclaron los fondos de las instituciones civiles y eclesiásticas en uno solo y los dividieron en cinco secciones: legislativa, administrativa, jurídica, de dominio público e histórica. Dentro de estas secciones, los documentos se clasificaron por lugares, fechas, reinados o por tipos documentales, con lo que se volvió imposible conocer la procedencia de los documentos (Fuster Ruiz, 1996: 43-77). Esta práctica se extendió por varios países de Europa.

En 1821, se creó la École de Chartes de París, que tenía la función de formar archivistas y bibliotecólogos. Las principales materias que se enseñaban eran Historia, Paleografía, Sigilografía, Filología y Diplomática, entre otras que preparaban a los alumnos para la crítica textual, metodología medular de la historia. Uno de sus objetivos primordiales fue publicar gran número de fuentes en conjunto con la División Histórica de los Archivos Reales. La Escuela cumplió con su cometido, pues pronto se publicaron dieciocho volúmenes de fuentes para estudiar las glorias francesas. Para 1831, Jules Michelet fue nombrado jefe de la División Histórica de los Archivos Reales, donde realizó meticulosas investigaciones sobre manuscritos y fuentes impresas; como resultado de ellas, en 1833 publicó el primer volumen de su monumental Historia de Francia. A partir de ahí, la archivística se volcó hacia el servicio de la historia (Brichfrod, 1989: 67-101).

De forma paralela, se gestaba un proceso de cientifización de la historia a la que el historiador alemán Leopold von Ranke dio un impulso significativo. Con ello, se afianzaron los estrechos vínculos entre la Historia y la Archivística. En 1824, Ranke publicó su primer libro, Historia de los pueblos romanos y germánicos desde 1494 hasta 1514. En el prefacio, dedicado a explicar sus métodos 
(los cuales se convirtieron en la base de la teoría de la historia), senala que es necesario recurrir a los documentos para observar "la Historia desde el interior." Criticó duramente toda forma de historiografía que no estuviera basada en fuentes primarias. Las fuentes tenían que mostrar "cómo realmente había sido". En trabajos posteriores, desarrolló un método histórico de interpretación que contemplaba el origen de la producción de los documentos, su entorno y las relaciones que hay entre ellos. La Filología fue el punto medular de su método de crítica textual para establecer la autenticidad y fiabilidad de los documentos ya que por medio del lenguaje empleado en los testimonios, podía comprobar la inserción de términos en desuso en una época determinada (Jeurguens, 2005).

En 1898, los historiadores positivistas Charles-Víctor Langloi ${ }^{1}$ y Charles Seignobos publicaron el libro Introducción a los estudios bistóricos. Al inicio del texto, en la parte dedicada a la Heurística, afirman que "La historia se hace con documentos. Los documentos son los vestigios de cuanto pensaron e hicieron nuestros antecesores", y que "los documentos son irreemplazables, sin ellos no hay historia" (Langlois y Seignobos, 2003: 59). La influencia de Ranke y del historicismo permeó a la Historia hasta bien entrado el siglo XX. Se tenía la convicción de que con el análisis crítico de las fuentes, quedaba garantizada la objetividad de la historia. Con esta perspectiva, las instituciones culturales, los museos, las bibliotecas y los archivos fueron considerados el centro del conocimiento universal; su función era hacer accesible el contenido de sus testimonios por medio de la clasificación y organización. En el clima científico-positivista del siglo XIX y el primer tercio del siglo XX, la publicación de fuentes críticas acordes con los postulados de la Heurística, además de la elaboración de catálogos e inventarios temáticos y cronológicos, fueron la principal función de la profesión archivística.

1 Quien posteriormente fue nombrado director de los Archivos Nacionales de Francia de 1913 a 1929, año de su deceso. 


\section{EL CAMINO HACIA LA RUPTURA ENTRE}

\section{LA ARCHIVÍSTICA Y LA HISTORIA}

El feliz matrimonio de poco más de un siglo entre la Historia y la Archivística empezó a mostrar los primeros síntomas de agotamiento precisamente en 1898 , pero ello no se debió únicamente a la publicación del manual holandés, sino al ya mencionado texto Introducción a los estudios históricos de Langlois y Seignobos, libro que, si bien fue muy cuestionado por las ideas positivistas que presentaba acerca de la Historia, tuvo una gran influencia entre los historiadores hasta la primera mitad del siglo XX. Sin embargo, en este artículo los mencionamos por las acerbas críticas que se hicieron en él contra los archivistas. Los autores expresaron que para que el historiador pueda realizar sus estudios, es preciso reunir todos los documentos que haya sobre el tema que se va a investigar, para lo que necesita la mayor cantidad de catálogos e inventarios de archivos. Como no había suficientes instrumentos descriptivos, los autores criticaron duramente a los archivistas que no se dedicaban a ello y en cambio hacían ediciones de documentos:

¿Quiénes, en la actualidad, han descubierto, analizado y publicado más documentos? Los archiveros, sin lugar a dudas. Esta circunstancia ha retrasado la catalogación de los documentos históricos. A la hora de la verdad, quienes tenían la obligación profesional de confeccionar los catálogos, fueron quienes menos los echaron en falta (Langlois y Seignobos, 2003: 69).

No sólo eso, sino que criticaron la elaboración de catálogos e inventarios: "la consecuencia más grave de la imperfección de los instrumentos actuales de la Heurística es sin duda que desanima a no pocos individuos inteligentes, conscientes de su valía que ven la desproporción entre su esfuerzo y su recompensa" (Langlois y Seignobos, 2003: 72).

Con ello inició el distanciamiento entre ambas disciplinas, el cual se reafirmó cuando los historiadores holandeses P. J. Blok y H. Brugmans censuraron el abandono del método cronológico en 
algunos procesos de la organización de los archivos. Expresaron que no tenían una opinión muy positiva de la organización sistemática que tomó su lugar y que fue presentado por la nueva generación de archivistas como método científico. Los debates que surgieron por las diferencias en la visión clasificatoria a menudo tenían un alto contenido emocional (Jeurguens, 2005).

\section{EL MANUAL HOLANDÉS Y LA DEFENSA \\ DE LA AUTONOMÍA DE LA ARCHIVÍSTICA}

El manual holandés de Muller, Feith y Fruin ha sido considerado el fundamento que brindó el estatuto científico a la Archivística. Para los archivistas de la época, fue una pieza básica en su lucha por la emancipación de la Historia, una lucha que duró poco menos de un siglo.

Sin embargo, el manual sólo es eso, un manual para aplicar la metodología archivística derivada de la Diplomática. Es decir, no es un tratado teórico; por lo tanto, dentro de las cien reglas que lo componen, no se menciona que sea una ciencia independiente de la Historia. Sólo en la número diecinueve, se dice que en el arreglo del archivo, los intereses de la investigación histórica se atenderán en segundo lugar. Establece que no es correcto romper el vínculo que la administración dio a los documentos en aras de formar legajos de los más diversos temas; en cambio, cuando se trate de documentos cuya procedencia no sea posible situar, se clasificarán de acuerdo con las preferencias de la Historia (Muller, Feith y Fruin, 1973: 53).

La defensa por la autonomía de la Archivística fue una respuesta a las críticas que los historiadores holandeses hicieron a los principios explicitados en el manual. Como antes mencionamos, el historiador P. J. Blok expresó que el arreglo cronológico era más útil, y Muller respondió explicando las desventajas de ello; por su parte, Blok contestó con una serie de ironías y afirmó que la Archivística sólo era una de las técnicas auxiliares de la Historia, negó su autonomía. Esta vez intervino Robert Fruin, quien en 1904 
declaró que los archivistas utilizaron los principios del manual holandés para emanciparse de la Historia, y que se oponía a que la Archivística fuese una ciencia auxiliar de la Historia, pues era una ciencia independiente. Otro historiador holandés, Van Deursen, se mofó de las revistas de Archivística que para ese tiempo ya eran numerosas, al decir que eran las únicas que se encontraban en la biblioteca de la universidad porque éstas nunca se las robaban, es decir, no interesaban a nadie (Brichford, 1989: 67-101).

A pesar de que los ataques continuaron durante décadas, el manual fue traducido al alemán en 1905, al italiano en 1908, al francés en 1910, al inglés en 1940 y al portugués en 1960, lo que indica su paulatina influencia, aunque hay algunos archivistas que hablan de su éxito inmediato. En 1922, sir Hilary Jenkinson produjo el segundo tratado sobre teoría y práctica archivística. El autor señaló que los archivos eran imparciales y ofrecían la más clara evidencia del pasado, por lo que los archivistas debían ser los guardianes de la santidad de la evidencia, que el archivista era "el devoto más desinteresado de la verdad”. En consecuencia, éste no debía intervenir en la desarticulación del archivo, pues ello socavaría la imparcialidad de los testimonios del pasado. De esta forma, Jenkinson siguió la línea positivista del manual y concluyó que los archivos eran un todo orgánico, que no debían organizarse de acuerdo con los postulados de la Historia. Su mayor aportación fue introducir el concepto de fondos, del que después se derivó la norma de descripción ISAD(G) (Cook, 1997: 17-63). En 1928, Eugenio Casanova publicó su libro Archivística, en el que se reflejan las corrientes intelectuales de su tiempo y afirmó que la "archivística es la ciencia de los archivos" porque se ocupa no solamente de su mantenimiento, sino de la construcción y el acondicionamiento de las instalaciones y el mobiliario, y agregó que es una ciencia autónoma, separada de la Historia, la Diplomática y la Filología (Casanova, 1928: 246 y 379). 


\section{LA DEFENSA DE LA AUTONOMÍA \\ DE LA ARCHIVÍSTICA EN EL SIGLO XX}

La recesión económica de Estados Unidos en 1929, provocó el surgimiento de la teoría del Records Managements (administración de documentos), cuyo principal exponente fue Theodore Shellenberg, quien la dio a conocer en 1956. Este nuevo postulado establecía que no toda la documentación debía conservarse y que los documentos debían gestionarse para decidir su permanencia o destrucción. Aunque esta teoría aún conserva remanentes de la relación de la Archivística con la Historia, provocó un verdadero revuelo entre archivistas e historiadores. En efecto, la selección documental marcó un verdadero hito en la teoría y las prácticas archivísticas a nivel internacional, así como acalorados debates en los que nuevamente intervinieron los historiadores, quienes dijeron que los archivistas se dejaban guiar demasiado por los intereses del Estado, ya que el principio de procedencia, base de la selección documental, sólo respondía a los valores gubernamentales. Este choque provocó otra ruptura, pues se cuestionaron los criterios con los que se destruirían los documentos, quiénes serían los encargados de semejante tarea, cuál sería su preparación, etc. Los archivistas se cobijaron en la autonomía de la Archivística, que no se regía por los intereses de otras disciplinas. La teoría de la evaluación documental no sólo originó protestas entre los historiadores, también ha recibido críticas de diversos profesionales, en especial de los llamados posmodernistas como Michel Foucault, Jacques Le Goff y Jacques Derrida (Cruz Domínguez, 2011: 55).

Un par de décadas después, en 1989, Elio Lodolini publicó el artículo "The War of Independence of Archivists", un título bastante sugestivo para el tema que nos ocupa, en el que denuncia la falta de reconocimiento de la autonomía de la Archivística. Empieza por decir que aún entre el público educado, a menudo se asocia el archivo con la biblioteca, o bien se considera al archivo como un simple instrumento de la investigación histórica. Refiere que en algunos países, se han unido la administración de archivos y bibliotecas en un solo organismo, basados en una supuesta afini- 
dad entre los dos, cuando los archivos y las bibliotecas son polos opuestos, y se lamenta de que la mayor organización cultural internacional, la UNESCO, tenga una sección en la que se enumeran sus oficinas no en orden alfabético, sino en orden jerárquico de importancia: Departamento de Documentación, Bibliotecas y Archivos (DLA).

Otra cuestión que le parece inaceptable es que en el sistema de clasificación decimal, creado por Melvil Dewey a finales del siglo XIX, se subsume la teoría archivística en el segmento de la Biblioteconomía. Así, el 0 es para "Obras Generales” y "Archivística” está en el 020, que es para "Biblioteconomía y Ciencias de la Información", lo que la reduce a un mero subconjunto de otra disciplina, de lo que se deriva que los archivos son parte de las bibliotecas. Agrega que, en la versión francesa de la Clasificación Decimal Universal, "Archivística" aparece en la clase 93, donde 930 es "Ciencia de la Historia y Ciencias Auxiliares de la Historia". En el 930.25, se encuentra "Archivística" y en el 930.251, "Técnicas de Archivo y Organización”. Por lo tanto, para el sistema Dewey, la Archivística es parte de la Biblioteconomía y en la Clasificación Decimal Universal, es parte de la metodología histórica. Se queja de que ninguno de los dos sistemas de clasificación admita la autonomía de la Archivística.

Refiere también que los artículos de Archivística han sido publicados en revistas de Bibliotecología y, en lo que se refiere a la formación de archivistas, ésta se ofrece en escuelas de Biblioteconomía. Señala que el archivista estadounidense George S. Ulibarri observó en 1961 que las diferencias entre los archivos y las bibliotecas han sido creadas por el progreso, que éstas han aumentado a medida que la profesión archivística se ha negado a permanecer subordinada a la profesión bibliotecaria. Lodolini añade que Urszula Rayska indicó que los archivos fueron depositados en las bibliotecas porque no existían edificios de archivo y que la Archivística es otra forma de Bibliotecología; además, hace alusión a un complejo de inferioridad que los archivistas han sufrido durante mucho tiempo y concluye que es hora de abandonar sus posiciones defensivas para mostrar que las diferencias entre los archivos 
y las bibliotecas. Escandalizado, Lodolini supone que hace tales aseveraciones porque en Estados Unidos la disciplina archivística no tiene tradición.

En cambio, en Italia, la Archivística como disciplina independiente empezó a enseñarse en los archivos estatales italianos a principios del siglo XIX. Afirma que los bibliotecarios italianos durante mucho tiempo han pugnado por crear escuelas independientes, aún más, en Italia no se requiere tener un título oficial de posgrado para ser bibliotecario, lo que sí sucede en los archivos. Por tanto, la situación italiana es completamente opuesta. Argumenta que el caso italiano no es un caso aislado porque los cursos y las escuelas de Archivística han existido en muchos países europeos desde el siglo pasado, con lo que la enseñanza de la ciencia archivística ha adquirido plena autonomía. Concluye diciendo que el archivista no debe tener en cuenta el interés de los estudiosos de otras disciplinas, que debe seguir exclusivamente los dictados de la Archivística, que es una ciencia completa en sí y que posee una dignidad igual a la de cualquier otra disciplina, es decir, que es una ciencia autónoma (Lodolini, 1989: 36-47).

Un siglo después de la publicación del manual holandés, la defensa de la autonomía archivística todavía continúa, sólo que con distintos matices. En 1999, Theo Thomassen publicó el artículo "Archivists Between Knowledge and Power on the Independence and Autonomy of Archival Science and the Archival Profession" que, como su nombre indica, es una defensa más por la autonomía de la Archivística en la que reúne parte de los postulados anteriores pero agrega algunas cosas más. Expresó que la disciplina debe desarrollarse en libertad académica que no debe tener la mera condición de una ciencia auxiliar y no debe ser subordinada a las instituciones archivísticas. De acuerdo con el autor, la Archivística no debe ser identificada como una ciencia auxiliar de la Historia o de las ciencias de la información y de la comunicación, ya que si es definida como una ciencia auxiliar, sus límites serán determinados a partir del punto de vista de las disciplinas dominantes, lo que obligaría a éstas a fijar la orientación de la formación y la investigación archivística. 
Para Thomassen, la Archivística debe ser independiente de los Archivos. Si la dirección de la educación y la investigación en la Archivística sólo estuviese determinada por las necesidades de los Archivos públicos, perdería su potencial innovador y sería confinada dentro de su campo de intervención tradicional. Después aborda la multidisciplinariedad de la Archivística y dice que una ciencia autónoma no está subordinada a otras disciplinas pero eso no significa que no se deba fomentar una estrecha relación con otras disciplinas y con los servicios de archivo. Afirma que la ciencia archivística puede y debe ser ejercida como una ciencia multidisciplinar, pero se debe tener en cuenta que la Archivística es joven, pequeña y débil y corre el peligro de perder su autonomía, especialmente en este periodo de transición, ante los retos e incertidumbres del desarrollo tecnológico, y la producción y el manejo de la información en el entorno electrónico y digital.

De acuerdo con Thomassen, la autonomía de la profesión se compone de dos elementos: autonomía profesional y autorregulación profesional. Entiende como autonomía profesional el derecho de las profesiones para indicar a los profesionales que deben prestar sus servicios en los archivos sin interferencias de ninguna índole. Autorregulación profesional es un sistema diseñado para controlar la conducta de los profesionales hacia la sociedad y para hacer una evaluación honesta y objetiva de otros temas relativos a la práctica de archivos. Así, para el autor una profesión es autónoma cuando las actividades profesionales se miden con los estándares y valores acuñados por la profesión, es decir, con un código de ética profesional que debe proporcionar las directrices generales que la deben regir. Agrega que la profesión archivística sólo puede ser independiente si la legislación archivística establece la independencia de la administración de archivos dentro de la administración pública y los archivistas son reconocidos como profesionales. La mayoría de ellos son funcionarios empleados por el gobierno; Thomassen alude a las experiencias que se han suscitado en todo el orbe al respecto, ya que el Estado no siempre actúa como el depositario del patrimonio y la memoria nacional, los archivos pueden ser utilizados por el gobierno de una mane- 
ra parcial, pues en ciertos casos se destruye deliberadamente el patrimonio cultural. Ante esta situación, los archivistas deben actuar de acuerdo con su código de ética (Thomassen, 1999: 149-167). Uno de los más álgidos y contradictorios problemas a los que se enfrentan la mayor parte de los archivistas es que son contratados por el Estado o por instituciones privadas, y si los empleadores disponen destruir la documentación, lo deben acatar, pues en caso contrario su trabajo estará en riesgo. El autor dice que la objetividad y la imparcialidad de los archivistas es la medida de su profesionalidad, y que es necesario resistir la presión para manipular pruebas o para ocultar o distorsionar los hechos. No obstante, conocedor de la realidad, asienta que "tenemos que admitir que la profesión y la disciplina archivística en su camino hacia la independencia y la autonomía todavía tienen un largo camino por recorrer".

La independencia y la autonomía de la Archivística y su profesión son vitales para la democracia, para la transparencia de los gobiernos y la rendición de cuentas, y para la preservación del patrimonio documental. Esta profesión debe demostrar a la sociedad que puede confiar en su integridad. El autor afirma que a pesar de que la profesión ha ganado sus guerras de liberación contra historiadores y bibliotecarios, no es totalmente autónoma. En el Congreso de archivistas realizado en Montreal en 1992, Liv Mykland declaró que la autonomía de la Archivística todavía es débil y limitada a pesar de los esfuerzos por obtener una identidad profesional. Thomassen (1999: 149-167) asegura que su independencia y autonomía tiene diversos grados dependiendo de las regiones y los países y aún dentro de ellos, de tal forma que la autonomía no se debe medir en términos absolutos. También advierte que la Archivística debe continuar su lucha por la independencia, la cual dependerá de la calidad de sus acciones, en especial cuando la política y la ideología traten de interferir en el campo profesional del archivista. 


\section{CONCLUSIONES}

Observamos que durante el periodo llamado precientífico, la Archivística sólo consistía en un conjunto de prácticas empíricas que estaban al servicio de la administración pública o privada; con el tiempo, creó vínculos con el Derecho, la Historia, la Diplomática y la Filología. La publicación del manual holandés justo en la época de la clasificación de las ciencias, ha sido blandida como estandarte científico de la disciplina, pero, como hemos visto, éste no es un tratado teórico, sino una serie de reglas para la organización y descripción de los archivos. La necesidad casi obsesiva de la Archivística por ser reconocida como una ciencia autónoma ha sido producto de acontecimientos ulteriores y del panorama científico que primaba en la época. A causa de ello, la relación de la Archivística con otras disciplinas ha estado dominada por la necesidad de demostrar que es una ciencia autónoma.

Los principios archivísticos han sido cuestionados por la duda posmodernista, que ha servido para que la Archivística vuelva los ojos a sus orígenes y se plantee nuevas líneas de investigación, ya que los documentos de archivo no garantizan la objetividad de la Historia ni de otras disciplinas. No es necesario insistir en su autonomía, que es característica del siglo XIX, sino que es preciso dedicar los esfuerzos a reflexionar en la multidisplinariedad siempre fructífera para atender los problemas que hoy la aquejan, como en la asunción de las tecnologías de la información y el poder de los archivos, que pueden ser manipulados para distorsionar la realidad pretérita y presente. Debe comprender su relación directa con las ideas de la memoria y la verdad. Si esto se olvida o se niega, si se persiste en la cómoda postura de observador imparcial, entonces será posible la pérdida de la autonomía, como señala Terry Cook. 


\section{BIBLIOGRAFÍA}

Albrech Fugueras, Ramón. (2003). Los archivos, entre la memoria histórica y la sociedad del conocimiento. Barcelona: UOC.

Brichford, Maynard J. (1982). "The origins of modern european archival theory". The Midwestern Archivist, VII-2: 67-101.

. (1989). "The Provenance of Provenance in Germanic Areas". En Journal of the Society of Georgia Archivists, 7- 2: 54-70.

Casanova, Eugenio. (1928). Archivística. Siena: Arti Grafiche Lazzeri.

Cook, Terry. (1997). "What is Past is Prologue: A History of Archival Ideas Since 1898, and the Future Paradigm Shift". Archivaria, 43: 17-63.

Couture, Carol y Jean Ives Rousseau. (1988 ). Los Archivos en el siglo XX. México: Archivo General de la Nación.

Cruz Domínguez, Silvana Elisa. (2011). "Archivística: objeto de estudio y sustento teórico". En Bibliotecología, archivística, documentación: intradisciplina, interdisciplina o transdisciplinariedad, 51-68. México: CUIB-UNAM.

Duranti, Luciana. (1993). "Origin and development of the concept of archival description". Archivaria, 35: 47-54.

Fuster Ruiz, Francisco. (1996). "Los inicios de la archivística española y europea”. Revista General de Información y Documentación, 6-I: 43-77.

Gilliland, Anne y Kelvin White. (2009). "Perpetuating and Extending the Archival Paradigm: The Historical and Contemporary Roles of Professional Education and Pedagogy". Interactions. Acceso el 10 de diciembre de 2014 en https://escholarship.org/uc/item/7wp1q908. 
Jeurgens, Charles. (2005). "Historians and Archivists: two Disciplines Working with the Same Papers". Acceso el 7 de enero de 2015 en http://www.let.leidenuniv.nl/ history/jeurgens/historians_and_archivists.pdf.

Langlois, Charles-Víctor y Charles Seignobos. (2013). Introducción a los estudios históricos. Alicante: Universidad de Alicante.

Lodolini, Elio. "The War of Independence of Archivists". Journal: Archivaria 28 (verano): 36-47.

Mendo Carmona, Concepción. (1995). "El largo camino de la archivística: de práctica a ciencia". Signo. Revista de Historia de la Cultura Escrita, 2, pp. 113-132.

Muller, S., Feith J. A. y R. Fruin. (1973). Manual de arranjo e descrição de arquivos, associação dos arquivistas bolandeses. Río de Janeiro: Ministério da Justiça, Arquivo Nacional.

Rodríguez de Diego, José Luis. (2005). "La otra documentación escrita. El Archivo de Simancas en el siglo XVI". En IV Jornadas Científicas Sobre Documentación de Castilla e Indias en el siglo XVI, 297-304. Madrid: Departamento de Ciencias y Técnicas Historiográficas. Universidad Complutense de Madrid.

Thomassen, Theo. (1999). "Archivists Between Knowledge and Power on the Independence and Autonomy of Archival Science and the Archival Profession". Archivaria, 28: 36-47.

Vivas Moreno, Agustín. (2004). "El tiempo de la archivística: un estudio de sus espacios de racionalidad histórica”. Ciencias de la información, 33-3: 76-96. 


\title{
Apuntes sobre los fundamentos científicos de la archivística
}

\author{
Merizanda M. C. Ramírez ACEves \\ Facultad de Humanidades \\ Universidad Autónoma del Estado de México
}

\section{INTRODUCCIÓN}

pesar de los múltiples textos doctrinarios que se han es-
crito para defender el carácter científico de la Archivística,
aún existen escépticos que desconfían de esta condición. Las dudas surgen porque la visión operativa o técnica que se tiene impide pensar sobre cómo el archivista construye, produce y difunde el conocimiento que genera a partir de su quehacer. Por lo que habría de cuestionarse: ¿Es la Archivística una técnica o una ciencia?, ¿cómo es que el archivista fundamenta los principios que hacen que la disciplina tenga un carácter científico y no técnico?

Es sorprendente que a 174 años de su nacimiento (si consideramos su surgimiento en 1841), la Archivística aún no haya terminado de convencer a quienes dudan de la delimitación de su campo de trabajo y su indiscutible lugar en la ciencia. Más aún, cuando en la actualidad el flujo de información y conocimiento en las instituciones no sería posible sin los órdenes establecidos por la Archivística. A pesar de esto, muchos se siguen inclinando por el carácter técnico de ésta.

Nada menos, se continúa abonando a esta confusión desde el momento en que se adoptan diferentes nombres para denominar a la 
disciplina, tales como Archivonomía, Archivología y Archivística, con el argumento de la practicidad de unos y la teorización de otros. Sin embargo, es posible suponer sus propios campos de estudio si se realiza un rápido análisis desde la estructura etimológica de cada uno de ellos. A lo anterior, se agregan términos como el de archivo, documento de archivo y gestión documental, entre otros más que siguen sin ser esclarecidos, lo que provoca una multiplicidad de conceptos que lejos de apoyar a la disciplina, la entorpecen y generan dudas sobre su naturaleza.

Hasta hoy, son muchos los textos que discuten y definen la Archivística como una ciencia. Entre ellos, destacan los de los archivistas clásicos como Theodore Shellenberg, Carol Couture y Sir Hilary Jenkinson, o de los contemporáneos como Antonia Heredia, José Ramón Cruz, Vicenta Cortés, Elio Lodolini, Concepción Mendo Carmona, Agustín Vivas, Eduardo Núñez, etc. Cada uno de ellos reflexiona sobre distintos asuntos, pero todos comulgan en la función social que tiene aun cuando la tecnología transforme los soportes en los que la información se manifiesta.

Por su parte, Miguel Ángel Rendón ha estudiado desde diversas aristas los fundamentos epistemológicos que hacen que no sólo la Archivística, sino la Bibliotecología y la Documentación sustenten su quehacer científico en la información, y que todas ellas formen en conjunto la Ciencia de la información (Rendón Rojas, 2011: 2005).

El hecho de que los documentos deben estar ordenados de una manera que facilite su acceso ha provocado discusiones sobre si la disciplina archivística es una técnica o una ciencia, ya que se apuesta por su carácter práctico. Giulio Battelli llegó a decir que los problemas de la Archivística son de carácter técnico, por lo que no hay en ello problemas científicos (Tanodi, 1961: 38). Sin embargo, está demostrado que existen métodos y principios que la posicionan como una ciencia, aunque emergente para unos y consolidada para otros. Lo que queda claro y todos defienden es que ésta se encuentra en un periodo de desarrollo y cambios de modelos provocados por la aparición de nuevas tecnologías que obligan a modernizar muchos de sus conceptos y a crear otros nuevos que generan nuevos debates. 
Nada menos, los documentos electrónicos, como soporte documental novísimo, han llegado a revolucionar los avances que ya se tenían sobre la teoría archivística, por lo que sus métodos y principios deben estar en constante actualización para ser más eficientes en su ejecución. Aunado a ello, el papel tradicionalista que tenían los archivos como sistemas semicerrados se ajustaron a las nuevas realidades demandadas por la garantía que debían otorgar a la sociedad de permitirle el acceso a la información de carácter público.

Con esto el papel del archivista cambió, dejó de ser el custodio de los documentos para convertirse en el actor principal y gestor de éstos, el vínculo entre la información que contienen y las necesidades sociales. Estos ajustes han provocado que la Archivística asuma una relación más administrativa, de corte moderno, en comparación con la anterior vinculación histórica, y amplía su espectro de usuarios de sólo historiadores y público en general a administradores y productores de la información. Lo anterior ha sido sólo la consecuencia del desarrollo que como sociedad estamos viviendo, pero eso no significa que la Archivística pierda su carácter científico, debemos ajustar su campo de acción y teorización a las nuevas realidades que la sociedad actual nos exige, hoy debemos retomar los elementos que hacen de ésta una ciencia en constante evolución.

Entonces, ¿cuáles son el objeto del estudio, los métodos, los principios y el fin que persigue la Archivística para convertirse en una disciplina científica? En este estudio se responderán estas interrogantes. La importancia de insistir en realizar estudios que defiendan el carácter científico de la Archivística radica en que debido a las transformaciones políticas, económicas, sociales y tecnológicas (factores que forman el acrónimo PEST, retomado por María Paz Martín-Pozuelo, 2010), se están modificando los antiguos arquetipos que surgieron en torno a ella, creando nuevos y se están replanteando su objeto de estudio, sus métodos, principios y fines.

Esta investigación repasará los nuevos elementos referentes al objeto de estudio, principios, métodos y fines que ha replanteado la Archivística como ciencia frente a los nuevos paradigmas desarrollados como consecuencia de las transformaciones sociales provocadas por distintos factores, entre ellos la aparición de nuevas 
tecnologías que facilitan diversos aspectos de la vida actual. Con ello se pretende beneficiar no sólo a la comunidad archivística, que es la que se convierte en el foro principal en el que se desarrollan los modelos científicos de la disciplina, sino brindar soluciones a los productores de documentos que, la mayoría de las veces, ven inundadas sus oficinas de papeles sin que haya quien, mediante la aplicación de los principios y métodos archivísticos, ponga fin a los hacinamientos documentales cada vez más frecuentes, no sólo los que están en papel como soporte, sino también los que transitan por el ciberespacio, y ayudar a la sociedad en general, que sigue sin entender del todo lo que es la Archivística.

Los recursos disponibles se basan fundamentalmente en los textos doctrinarios tanto en soporte papel como en digital que se han publicado y que pretenden esclarecer los aspectos que hacen que la Archivística haya pasado de ser una disciplina basada en una actividad práctica, a una ciencia con objetos, principios, métodos y fines claramente definidos y aceptados por la comunidad científica. La Archivística es una ciencia que se está consolidando por sus propios méritos y por las cada vez más amplias funciones tanto empíricas como científicas que está desarrollando. Esta idea deja ver la existencia de un proceso evolutivo que puede basar su fundamento en el conocimiento científico caracterizado por la presencia de una línea creciente que va de lo simple a lo complejo y que, por lo tanto, asume de manera progresiva mayores niveles de organización.

Para que una ciencia sea aceptada como tal, debe cumplir tres requisitos fundamentales: tener un campo específico de investigación u objeto de estudio que será estudiado para producir un conocimiento por causas; establecer leyes universales o investigar una verdad, y, finalmente, tener un método propio y un fin específico. Si se considera todo lo anterior, habría que preguntarse entonces: ¿cuál es la manera de construir una hipótesis para considerar a la Archivística una ciencia?, ¿cuál debería ser su objeto de estudio, sus leyes universales, su método, sus principios y su fin? La Archivística, como cualquier otra ciencia, necesita de principios teóricos inferidos de la práctica o la costumbre para legitimar su carácter científico. 
Se puede adelantar que el objeto de estudio de la Archivística se encuentra en los fondos documentales y en los archivos, y trata de resolver de manera doctrinaria cómo se forman, organizan y conservan. Por otra parte, la Archivística parecería tener teorías y métodos de investigación aceptados de manera generalizada entre la comunidad científica, conformados por bastos fundamentos doctrinales y una centenaria aplicación práctica en los archivos. Es un hecho comprobado y aceptado que la Archivística encuentra su fundamento en el principio de procedencia, según el cual los documentos forman parte de un fondo cuya característica es la conformación de una unidad orgánica indivisa. En éste quedan inscritos los principios de respeto de los fondos ${ }^{1}$ y respeto al orden original. ${ }^{2}$

En cuanto al método, cabe hacer mención de que éste debe ser entendido como el conjunto de prescripciones y decisiones destinadas a probar un conocimiento ajustado a la realidad de una ciencia en particular. El método en Archivística está obligado a examinar un conocimiento desde una perspectiva teórica para encontrar una justificación sólida en el momento de su aplicación. Para algunos autores, el método está constituido por lo que se denomina gestión documental o tratamiento documental, que consiste en un conjunto de operaciones y tareas que se aplican a los documentos en cada una de las fases de su ciclo vital y que tiene como objetivo organizarlos, conservarlos, y hacerlos accesibles, manejables y útiles en sus diversos fines (Duplá del Moral, 1997). Las tareas fundamentales de la Archivística son la identificación, organización (clasificación y ordenación), valoración y descripción, así como el almacenamiento de los documentos que son fundamentales para que el archivo sirva los documentos a los usuarios que los demandan. Es en este ele-

1 Consiste en "mantener agrupados, sin mezclarlos con otros, los documentos provenientes de una administración, un establecimiento, o una persona natural o moral determinados" (Duchein, 1985: 69).

2 Consiste en "mantener la disposición original en que han ido surgiendo los documentos, fruto de las actividades y procedimientos seguidos en la institución, de este modo se mantiene la conformidad estructural del fondo archivístico" (Vivas Moreno, 2011: 46). 
mento donde se puede observar con claridad los aspectos pragmáticos -basados en la crítica, el razonamiento y el rigor científico- que la Archivística aplica con el objeto de lograr su fin. También existen otro tipo de métodos en esta área como los de periodización, representación imaginaria e imagen social.

Por último, el fin que persigue la Archivística es el de hacer recuperable la información tanto para uso de las instituciones administrativas, como de la investigación, siempre y cuando ésta cumpla con tres condiciones definitorias, a saber:

- Que la información haya sido producida por personas físicas o jurídicas en el desarrollo de sus funciones administrativas.

- Que sea la consecuencia de procesos establecidos de manera formal.

- Que la creación de los documentos esté regulada por normas legales o por procedimientos internos.

\section{EPISTEMOLOGÍA DE LA ARCHIVÍSTICA}

Las ciencias surgen por la necesidad que tiene el hombre de entender su realidad, explicarla y resolver los problemas que se le dificultan. Éstas han sido influenciadas por dos grandes corrientes: la primera es aquella que entiende la ciencia como la explicación que da razón de los fenómenos (corriente positivista) y, la segunda, la concibe como la interpretación causal de los hechos (corriente racionalista). Independientemente de la escuela que se utilice, lo cierto es que ambas buscan un fin común: llegar a la verdad mediante la aplicación del conocimiento científico.

La epistemología juega un papel destacado en la construcción del conocimiento científico de la disciplina referida, pues a través de su aplicación es posible establecer cómo es que se genera el saber archivístico y, por tanto, cómo un área del conocimiento puede llegar a ser ciencia, además de determinar los criterios bajo los cuales se construye y explica. 


\section{OBJETO DE ESTUDIO}

El objeto de estudio de la Archivística está compuesto por dos elementos esenciales: los archivos y los documentos de archivo.

\section{El Archivo}

Una de las teorías que han definido el término Archivo establece que éste se deriva del latín archivum, proveniente a su vez del griego arkeion (residencia del arconte, un personaje público que asumía un cargo en el gobierno) y se refería tanto al lugar donde se resguardan los documentos, como a éstos allí resguardados. Desde esta perspectiva, el archivo tuvo una connotación ligada a la administración pública, aunque hay que advertir que hay autores que incluyen también el ámbito privado.

La definición ha sufrido transformaciones a lo largo del tiempo. Sir Hilary Jenkinson fue quizá el pionero en proponer a finales de la década de los veinte una definición cuando se refirió al archivo como:

[...] los documentos acumulados por un proceso natural en el curso de la tramitación de los asuntos de cualquier tipo, público o privado, en cualquier fecha y conservados después para su consulta bajo la custodia de las personas responsables de los documentos en cuestión o por sus sucesores (Jenkinson, 1922: 237). 
En años posteriores, autores como Theodore Shellenberg, ${ }^{3}$ Elio Lodolini, ${ }^{4}$ Antonia Heredia, ${ }^{5}$ Manuel Romero ${ }^{6}$ y Vicenta Cortés ${ }^{7}$ abonaron a la disciplina definiciones que no distaron de la propuesta del archivista inglés, pues todos ellos se refirieron al archivo como el conjunto de documentos derivados de las funciones institucionales, es decir, aludieron al contenido y no al continente. No obstante, cada uno le dio un tamiz característico, pues para Shellenberg sólo pertenecían a este grupo los documentos históricos, postura contraria a la de Lodolini, para quien los archivos eran tanto los documentos generados en el seno administrativo, como los que alcanzaban el carácter histórico. Vicenta Cortés y Antonia Heredia en cambio, los diferenciaron entre públicos y privados, generados y recibidos, de referencia y testimoniales sin importar su fecha. Romero, por su parte, se limitó a llamarlos "colección". En el Diccionario de terminología archivística, ${ }^{8}$ la visión ante este objeto fue muy distinta, toda vez que su orientación se centró en

3 "Los registros de cualquier institución pública o privada que hayan sido conservados con fines de investigación en una institución archivística" (1956: 43).

$4 \quad$ "El conjunto de material documental" (1993: 67).

5 "Conjunto de documentos, sea cual sea su fecha, forma y soporte material, acumulados en un proceso natural por una persona o institución pública o privada en el transcurso de su gestión, conservados, respetando aquel orden, para servir como testimonio e información para la persona o institución que lo produce, para los ciudadanos o para servir de fuentes de historia" (1995: 89).

6 Colección de documentos reunidos por una entidad en el ejercicio de una actividad práctica y necesaria, conservados en un lugar seguro como memoria fiel para servir testimonio e información (1997: 17).

7 Conjunto de documentos acumulados en un proceso natural por una persona o institución pública o privada en el transcurso de la gestión de asuntos de cualquier índole, los producidos y los recibidos, de cualquier fecha, los cuales se conservan y custodian para servir de referencia, como testimonio e información, por las personas responsables de tales asuntos y sus sucesores (2007: 52).

8 La institución cultural donde se reúnen, conservan, ordenan y difunden los conjuntos orgánicos de documentos para la gestión administrativa, la información, la investigación y la cultura. El local donde se conservan y consultan los conjuntos orgánicos de documentos (2011: s/p). 
el archivo como la institución responsable de la reunión, tratamiento y conservación de los documentos; es decir, lo concibió como un continente y no como un contenido.

En años recientes, Antonia Heredia (2007) planteó una propuesta que busca seguidores: el uso de la mayúscula para el término Archivo como institución, es decir, como continente, y de la minúscula para el contenido documental. Así, el Archivo —con mayúscula - sería definido como la institución encargada de la reunión, el tratamiento, la conservación, el uso y el servicio de los documentos que han sido generados por las instituciones administrativas para uso informativo y de investigación.

Como se puede observar, el significado del archivo ha ido cambiando no sólo desde la propuesta de Sir Hilary Jenkinson en los años veinte, sino que desde la Antigüedad Clásica ya se comenzaba a visualizar éste como el recinto de custodia de los documentos. Esta visión se modificó durante el siglo XX al ser considerado sólo el conjunto de documentos producidos y recibidos por las instituciones. Sin embargo, a comienzos del nuevo milenio llegó Antonia Heredia con esta innovadora propuesta que se constituye como un avance más del desarrollo paulatino que la ciencia archivística ha tenido desde sus inicios hasta el día de hoy.

\section{El documento de archivo}

Otro de los objetos de estudio de la Archivística son los documentos del archivo. La voz documento encuentra sus orígenes etimológicos en la palabra latina documentum, derivado del término docere, que significa "enseñar" o "instruir". Así, el documento es el soporte material en el que se plasma la información con el fin de transmitirla a los demás. La definición de documento ha tenido variantes con el paso del tiempo y ha sido empleado con distintos significados por diferentes disciplinas. El documento como testimonio histórico data del siglo XIX, cuando la escuela histórica positivista lo identificó como un texto escrito, pero no fue sino hasta la sexta década del siglo XX que se le comenzó a dotar de otros atributos como el de contener imágenes gráficas y/o audiovisuales. 
Algunos diccionarios especializados como el de Buonocore, el de Pernía y, más recientemente, los de la Real Academia de la Lengua Española (RAE) y el de Terminología Archivística, ofrecen algunas definiciones sobre la acepción. Para el primero, por ejemplo, el término documento tiene distintos significados según la disciplina jurídica, diplomática, documental o archivística desde la que se estudie. Así pues, desde el punto de vista jurídico, el documento se define como "todo testimonio escrito, redactado de acuerdo con ciertas solemnidades, que establece y que tiene por fin un acto jurídico" (Buonocore, 1976: 243). A esta categoría específica de documento, se la denomina instrumento. De esta manera, un instrumento jurídico se materializa en las constituciones, los tratados internacionales, los precedentes judiciales o los códigos de conducta, entre otros. La definición no dista mucho de la anterior desde el punto de vista diplomático, pues lo único que se le añade es el sentido utilitario de éste para la Historia.

La opinión de los documentalistas en relación con el término, en cambio, ha sido quizá la que más estudios ha producido, desde la obra de Paul Otlet en los años treinta, a quien no por casualidad se lo reconoció como el padre de la Documentación. Él definió el documento como "la memoria materializada de la humanidad, en la que día a día se registran los hechos, las ideas, las acciones, los sentimientos, etcétera, que han impresionado el espíritu del hombre" (Otlet y Ayuso García, 1996: 25). Desde luego, esta definición dejaba ver la función informativa y preservadora que el documento debía manifestar para ser considerado como tal.

En la misma línea de Otlet, se manifestaron documentalistas como López Yepes ${ }^{9}$ y Guinchat-Menou, ${ }^{10}$ entre otros. Sin embargo, como se puede observar, las definiciones aportadas por estos especialistas dejan entrever un amplio espectro de posibilidades de lo que puede ser un documento. Ello se debe a que el estudio de este

9 "Una forma objetiva de conocimiento riguroso fijado y conservado en un soporte y potencialmente apto para ser transmitido" (1977: 60).

"Un objeto que transmite un dato o una información" (1983: 41). 
soporte material es un objeto de análisis de la Ciencia de la documentación, considerada por López Yepes como:

El conjunto de las disciplinas relacionadas con el estudio del documento como fuente de información para obtener nueva información o una toma de decisiones, disciplinas [...] o, si se prefiere, el estudio de los procedimientos netamente informativos subsiguientes al tratamiento técnico de los documentos para la eficaz difusión de los mensajes en ellos contenidos (1993: 141).

Las disciplinas a las que se refiere esta definición son, entre otras, laz Bibliotecología, Bibliología, Archivística, Museología y Ciencia de la Información. Esto hace que las definiciones dadas desde la perspectiva de la Documentación muestren generalidades que confunden su contenido en las particularidades de cada ciencia. Ya lo decía Evaristo Jiménez, "lo que queda claro es que la idea de documento, en la perspectiva de la Documentación, carece virtualmente de límites" (1987: 6).

Desde la visión archivística, el documento es la materia prima de los Archivos, pero no desde una visión general sino más bien específica en cuanto lo conceptualiza como documento de archivo, puesto que para esta disciplina el documento y documento de archivo no son lo mismo. Esta diferencia se comenzó a marcar desde hace poco menos de treinta años. La década de los ochenta marcó un antes y un después en la consolidación de un término que hasta ese momento comenzaba a ser discutido entre la comunidad archivística. Antes de esa época, se hablaba, casi de manera exclusiva, de un documento exportado de otras disciplinas relacionadas con el manejo de la información, y no fue sino hasta veinte años antes de iniciar el siglo XXI, que al término se le agregó de archivo y tuvo aportaciones de los más reconocidos y prestigiados archivistas contemporáneos. Así pues, no es lo mismo hablar de documento que de documento de archivo, pues este último se halla inserto en el primero y no al revés.

Fue Humberto Pernía quien definió al documento desde este ángulo como "cualquier papel conservado en un Archivo que comu- 
nica algo y relacionado con algún organismo público o privado" (Pernía, 1990: s/p) en la primera edición de su obra publicada en los años setenta. Como se observa, el documento de archivo no sólo es el registro que contiene información para ser difundida, ni mucho menos su contenido es científico, tal y como lo han manifestado algunos documentalistas, porque de ser así este carácter erudito no se podría manifestar en los documentos que generan las instituciones; más bien, su misión se centra en testimoniar las funciones que éstas han desarrollado a lo largo de su existencia, por lo que es la función administrativa la que caracteriza y da sustento y razón de ser al documento de archivo, a diferencia de la misión científica que plantea el documento estudiado por la Documentación.

Por otro lado, el Diccionario de la RAE hace una aportación interesante pues, aunque lo concibe tan sólo como documento, su definición está pensada en razón de un documento de archivo, al que define como "el escrito en que constan datos fidedignos o susceptibles de ser empleados como tales para probar algo" (2011: s/p). La prueba a la que se refiere la obra constituye los testimonios de un hecho, es decir, la manera de actuar de las instituciones frente al desarrollo de sus actividades cotidianas.

Theodore Shellenberg, uno de los archivistas estadounidenses más reconocidos de los años cincuenta, llegó incluso a establecer algunos criterios para determinar la importancia de los documentos de archivo con el ánimo de conservarlos de manera permanente en los Archivos históricos. Su aportación se centró en establecer algunas pruebas para determinar tanto los valores evidenciales, como los informativos para almacenarse en este tipo de Archivo. Para reconocer los valores evidenciales, subrayó que la apreciación de éstos debe hacerse sobre la base de un conocimiento general de todos los documentos de archivo de una dependencia y no sobre una base parcial. Por otro lado, estableció que los documentos que hablaran sobre los orígenes de la institución y los referentes a programas sustantivos serían, sin lugar a duda, documentos de archivo. En cuanto a la apreciación de los valores informativos, señaló la aplicación de pruebas de exclusividad, forma e importancia para 
determinar aquellos que entrarían en la categoría de documentos de archivo (Shellenberg, 1956).

Finalmente, al remitirse al documento, el Diccionario de terminología archivística la define de la siguiente manera: "Toda expresión en lenguaje natural o convencional y cualquier otra expresión gráfica, sonora o en imagen, recogidas en cualquier tipo de soporte material, incluso los soportes informáticos. Se incluyen los ejemplares no convencionales de ediciones". Esta misma definición se utilizó en la Ley de Patrimonio Histórico Español de 1978. Sin embargo, más adelante la definición continúa diciendo que un documento de archivo es "el testimonio material de un hecho o acto elaborado de acuerdo con unas características de tipo material y formal". Queda claro que no es casualidad que en este diccionario estén diferenciados los documentos y los documentos de archivo, más bien, se defiende la idea de que son elementos distintos.

Esta misma idea es defendida por la comunidad archivística, entre la que destacan archivistas como Aurelio Tanodi, ${ }^{11}$ José Ramón Cruz Mundet, ${ }^{12}$ Alberch I Fugueras, ${ }^{13}$ María Paz Martín-Pozuelo, ${ }^{14}$

11 "El soporte que contiene un texto que es el resultado de una actividad administrativa de una entidad, efectuada en cumplimiento de sus objetivos y finalidades. La actividad administrativa se toma en su sentido extenso, de las gestiones internas y trámites internos y externos considerados de índole administrativa, contable (económico-financiero) y jurídica (que dan pruebas sobre derechos y deberes)" (1981: 38).

12 "La combinación de un soporte y la información registrada en él que puede ser utilizado como prueba y consulta" (1994: 99).

13 "Conjunto integrado por un soporte y la información que contiene, utilizable con finalidades de consulta y como prueba” (2003: 67).

14 "Documento que resulta de un proceso administrativo o jurídico, así como todos aquellos que hacen posible tal proceso, recogidos en un Archivo, donde paulatinamente van prescribiendo sus valores originales sustituyéndose por otros de prueba e información" (1996: 108). 
Antonia Heredia ${ }^{15}$ y Manuel Romero Tallafigo ${ }^{16}$ por mencionar sólo a algunos, quienes a pesar de utilizar el término documento, aportan definiciones correspondientes al documento de archivo.

Queda claro que el documento de archivo es el objeto sobre el que el archivista ejerce su actividad. Éste supone el testimonio de la acción del ser humano fijado en un soporte material perdurable sin importar su forma, fecha y contenido, producto de las funciones administrativas desarrolladas por una institución pública o privada. Está constituido por tres elementos fundamentales:

- Contenido: En él se testimonian las acciones cotidianas de una institución como consecuencia de sus funciones administrativas.

- Productor: El productor es toda persona física o jurídica que genera un documento como consecuencia del contenido al que se aludió anteriormente, sin importar la fecha en que éste se elaboró.

- Soporte: Las definiciones coinciden en que el soporte material en el que se objetiva el contenido puede ser de diversa índole como se verá más adelante.

Para identificar con mayor precisión un documento de archivo, se debe partir de reconocer las características que lo diferencian del resto de los documentos. Juana Molina y Victoria Leyva (2000) reconocen las siguientes:

15 "El lugar donde se conservan los documentos, así como los documentos mismos, producidos por una organización en el ejercicio de sus funciones con fines jurídicos, administrativos y/o en casos meramente informativos" (1995: 122).

16 "Que contiene información o testimonio en cualquier soporte, formato y fecha y por cualquier medio o lenguaje que ha sido recibido o expedido en el ejercicio de sus funciones legales o transaccionales de negocios por una institución o persona que lo conserva para testimonio y prueba y continuidad de su gestión" (1997: 127). 
- El génesis u origen. El documento de archivo nace dentro de un proceso natural de las actividades llevadas a cabo por personas o instituciones; por tanto, son el testimonio material de las funciones ejercidas por su productor. El proceso natural al que se hace referencia permite crear agrupaciones documentales naturales, entre las que destacan el fondo, la sección, la serie, el expediente y la pieza documental. Esto significa que todo aquel documento que no forme parte de las funciones institucionales, no puede ser considerado un documento de archivo ni mucho menos se puede incluir en una agrupación documental natural.

- El carácter seriado. Como los documentos de archivo son el reflejo de una función establecida en el marco legal institucional, está claro que deben constituir una acción repetitiva, esto es, que los documentos de archivo se deben generar de manera permanente. Esta manera reiterada de generar documentos hace que de manera natural se generen series documentales. Una serie documental es el conjunto de unidades documentales de estructura y contenido homogéneos emanados de un mismo órgano o sujeto productor como resultado del ejercicio de sus funciones. Los fines que persiguen las series documentales son: testimoniar los soportes documentales de la función administrativa; agrupar los documentos de una misma competencia y de las funciones reglamentarias; procurar su permanencia en el tiempo; permitir la investigación y consulta de manera efectiva, eficiente y eficaz, y permitir la creación de expedientes físicos y virtuales homogéneos a través de la identificación, jerarquización y codificación.

- La condición de exclusivos. Los documentos de archivo, a diferencia de otro tipo de documentos, como los libros, no producen ejemplares, antes bien, cada documento de archivo es producto de una actividad concreta de un sujeto productor que se refiere a un asunto específico en el que está involucrada una persona en particular. Así, aunque la actividad sea repetitiva, la información que se plasme en cada documento se- 
rá exclusiva y nunca será idéntica a la de otro documento.

- Su unicidad o condición de originales. Los documentos de archivo son únicos y originales a diferencia de los ejemplares múltiples (editados). Al ser generados como consecuencia de un acto administrativo por un órgano como prueba o testimonio del mismo, contienen elementos de validación indispensables que les dan un carácter probatorio o testimonial como integridad, autenticidad e ingenuidad. La integridad se refiere a que los documentos de archivo no les debe faltar ninguna de las siguientes partes: soporte, formato, cantidad, tipo (elementos externos), autor, fecha y asunto (elementos internos); la autenticidad significa constancia fehaciente de la autoría del documento, esto es, que los elementos como el autor, la fecha, el lugar y el asunto, deben ser verdaderos; finalmente, la ingenuidad está relacionada con la condición del documento, que puede ser borrador, copia u original, pero nunca será un ejemplar múltiple.

Los documentos de archivo contienen una serie de aspectos externos e internos que los diferencian del resto de los documentos estudiados por la ciencia de la Documentación. Estos son los siguientes:

\section{Caracteres externos}

- $\quad$ Clase. Se refiere al medio empleado para transmitir la información. Por su clase, los documentos de archivo de clasifican en textuales, gráficos, fotográficos, sonoros, audiovisuales e informáticos.

- Soporte. Es la materialización física del documento de archivo, esto es, los materiales utilizados para su configuración y posterior manipulación. Estos se cla- 
sifican de la siguiente manera: soportes en papel (artesanal o industrial), fotográficos (filmes, fotografías, microformas, etc.), magnéticos (cintas de video, cintas de casete, diskettes, etc.) y ópticos (CD ROM, DVD, etc.).

- Formato. Es la forma en la que se presenta el documento de archivo, el tamaño y sus dimensiones. Así, los documentos en soporte papel se pueden presentar en expedientes tamaño cuartilla, carta, oficio, DIN A4, DIN A3, entre otros y los soportes magnéticos en diskettes como 5 1/4 O 3 1/2 pulgadas, por mencionar sólo algunos.

- Cantidad. La cantidad se refiere al número de unidades y espacio que ocupan los documentos de archivo en metros lineales, que pueden ser volúmenes, legajos o cajas.

- Forma. Se refiere a la condición de originales, copias o borradores.

- Tipo. Se relaciona con la disposición de los elementos de información que contienen los documentos. La estructura del documento proviene de una actividad administrativa. Así, los tipos documentales serán tantos como actividades realice la institución. Estos pueden ser: oficio, memorándum, acta, informe, estadística, etcétera.

\section{Caracteres internos}

- Entidad productora. Es la persona o institución que generó los documentos, esto es, su autor.

- Origen funcional. Es la razón por la cual se producen los documentos. Hay que recordar que éstos son consecuencia de una función administrativa atribuida al organismo productor.

- Fecha y lugar de producción. Corresponde a la data crónica y tópica en la que se generó el documento.

- Contenido. Tema o asunto del que trata el documento.

En definitiva, lo que queda claro es que no se pueden utilizar los términos documento y documento de archivo de manera indis- 
criminada, pues el segundo está dentro del primero y no de manera contraria. Así pues, el documento de archivo es aquella manifestación que expresa las funciones administrativas de una institución, ya sea pública o privada, que sirve de testimonio y prueba de los hechos acontecidos y en el cual no importan el lugar, la fecha y el soporte utilizados.

\section{MÉTODOS Y PRINCIPIOS CIENTÍFICOS DE LA ARCHIVÍSTICA}

Como ya se ha señalado, son muchos los trabajos que han tratado de explicar el carácter científico de la Archivística de diversas maneras. Una de las más recurrentes ha sido a través del establecimiento de métodos propios con principios claramente establecidos.

Uno de ellos es el de la periodización como un método para analizar los procesos históricos que han influenciado en el desarrollo de la ciencia archivística. Al respecto, Guillermo Bauer (1970) llegó a establecer tres principios básicos para utilizar este recurso en cualquier campo de estudio en los años setenta del siglo XX:

- $\quad$ El periodo debe ser deducido de su objeto, es decir, de los hechos históricos o las concepciones de la época que abarca.

- Todo periodo debe constituir un conjunto naturalmente bien delimitado y configurado en sí mismo que se distinga con claridad del que le precede y el que le sucede.

- Los puntos de vista para la distinción de los periodos deben ser de naturaleza uniforme.

Autores como Antonia Heredia y José Ramón Cruz utilizaron el método baueriano para tratar de establecer la evolución de la Archivística y cómo pasó de ser una disciplina empírica y práctica a una teoría científica que ha delimitado su campo de acción; de limitada acción, a una ampliación del campo de actuación, y de ejercer función coercitiva a ser una necesidad informativa (Vivas Moreno, 2005). 
Otro método adoptado en el análisis histórico de la Archivística es a través de su representación imaginaria o imagen social, para el que las fuentes indirectas son de gran trascendencia, pues son las que enmarcan al archivo en el contexto sociocultural con la intensión de reconocer la percepción social, es decir, la imagen que la sociedad tiene de estas unidades documentales. Se debe recordar que por mucho tiempo los Archivos han sido considerados lugares lúgubres en los que se acumulan montones de papeles polvorientos sin ningún valor. Hay quienes, de manera ingenua, los llegan a identificar como "archivos muertos", denominación ante la cual, con cierta picardía y diversión, los especialistas en Archivística se plantean la pregunta, ¿y quién los mató?, pues lejos de ser cementerios repletos de cadáveres, son recintos que resguardan valiosos testimonios escritos que constituyen parte del patrimonio documental de una sociedad. No obstante su relevancia, el desplante que de ellos hacen incluso los propios productores, que son los que deberían engrandecerlos puesto que son los que les dieron vida -y que luego pretenden matar-, las personas los siguen sobajando sin ser conscientes de sus múltiples beneficios. Nada menos, desde que se implementaron en este país en el año 2002 las políticas públicas relativas a la rendición de cuentas, los Archivos son por naturaleza los garantes del derecho de acceso a la información.

Hay que resaltar el hecho de que los Archivos surgieron el mismo momento en el que surgieron en las instituciones como un mecanismo que procura ordenar y normar el comportamiento social. La familia fue la primera institución en formarse, es la base de la sociedad que, además de procrear hijos, les inculca valores y les fomenta hábitos de convivencia, costumbres, modales, sentimientos, devociones y lealtades. A ésta le siguen el sistema educativo, que como institución social potencia el desarrollo integral de los alumnos para una mejora colectiva; la religión, que regula la conducta moral — que no racional- del hombre; el sistema económico, que influye en la vida diaria para adquirir los satisfactores que brinden comodidad y seguridad o, simplemente, satisfagan las necesidades más básicas del ser humano, y el gobierno como máximo regulador de las relaciones sociales. Todas ellas son inter- 
dependientes, es decir, no puede subsistir una sin el apoyo de la otra. Estas instituciones han ido creando documentos, en primer lugar, para dar continuidad a los trámites administrativos y, en segunda instancia, para dar testimonio y evidencia de estos. Así pues, los archivos son importantes para la Administración pero también para la Historia. A pesar de esa trascendencia, la sociedad sigue percibiendo de ellos otra cosa y les otorga una condición eminentemente irrelevante.

Para el uso de este método (el análisis histórico), se han de establecer los principios que deben regirlo, tal y como lo hizo en su momento Guillermo Bauer en su método de periodización histórica.

Agustín Vivas propuso el uso de las memorias y relatos de viajeros como un ejemplo de fuente indirecta para el uso de este método, pues la descripción de lugares y pueblos originan "una multitud de géneros que tienen en común el dar cuentas a los demás de la aventura personal" (2005: 53). De ser así, los principios fundamentales de las memorias y relatos de viajeros serían:

- $\quad$ El itinerario, que se convierte en el elemento principal de la construcción de relatos de viajes.

- La descripción, como elemento organizador del itinerario.

- La sorpresa, como efecto literario, que destaque lo raro y exótico de los lugares.

- El humor, pues favorece la lectura.

- Elementos preliminares, como instrumentos de utilidad para captar al lector que intenta conseguir una cierta moralidad.

Las características que se deberían obtener con el análisis de estas fuentes serían la instrumentación política del archivo y el importante papel que representa la burocracia; la visión del archivo como salvaguarda y garantía jurídica; la vinculación de los archivos con la memoria histórica; la práctica eclesiástica, y la cultura escrita. En suma, la aplicación de estos elementos ofrece interesantes valoraciones sobre diferentes aspectos que permiten vislumbrar la historia imaginaria pero, ¿qué hay de la percepción actual de los Archivos? A pesar de la propuesta de Agustín Vivas, habría 
que pensar en el análisis de otro tipo de fuentes para ampliar este método, como podría ser la entrevista a personas vinculadas con los Archivos u otros miembros de la sociedad para conocer la realidad contemporánea y establecer así sus principios.

Otro de los métodos más reconocidos en esta área y sobre el que más se ha abonado es el del principio de procedencia o método storico - como lo denominaron los italianos F. Bonaini, Eugenio Casanova, Georgio Cencetti y Elio Lodolini, al cual reconocen como el auténtico y único válido método archivístico- que se comenzó a gestar desde el siglo XIX y que se basa, a su vez, en el método analítico y tiene como objetivo conocer a la institución productora de los documentos. Su aplicación está fundamentada en dos niveles o grados. El primero, se circunscribe a la institución u organismo que constituye el fondo de archivo, cuya organización debe mantenerse en su estado original, y no deben mezclarse los documentos procedentes de un organismo con los de otro. El segundo nivel responde al respeto por el orden original, esto es, los fondos de archivo deben conservar o recibir la clasificación correspondiente a las estructuras internas del organismo que lo ha creado y, al interior de cada serie, debe respetarse el orden que los documentos tuvieron de origen, lo que responde a un criterio de ordenación (Mendo Carmona, 2004).

La divulgación de los principios archivísticos de procedencia y orden originario se ha venido consolidando en dos posiciones teóricas claramente diferenciadas: por un lado, se encuentra la tradición minimalista y, por otro, la maximalista (Núñez Fernández, 1999). La primera de ellas, parte de las premisas expuestas por Natalis de Wailly en 1841, seguido de J. Papritz y A. Szedö, quienes afirman lo siguiente con respecto al principio de procedencia:

[...] si ocurre, muy raramente, que una administración transfiere sus papeles perfectamente clasificados, la perfecta clasificación, será respetada en los Archivos. Pero cuando el sistema de clasificación de los papeles no es perfecto, o bien, el sistema razonable en sí mismo, no es ejecutado con exactitud, todos son del parecer de que es justo modificar la clasificación inicial o aplicar de manera cohe- 
rente el sistema adoptado por la administración. Si se adopta un nuevo sistema de clasificación, se respetan siempre la estructura de la institución y la función de los documentos (1999: 179).

La segunda tradición, la maximalista, fue iniciada por F. Bonaini en 1867, y su premisa de organizar los documentos con base en el respeto al orden originario o primitivo del fondo se resume de la siguiente manera: "[...] los documentos deben ser conservados en el fondo en el orden que han recibido; si este orden ha sido alterado o destruido, será restaurado tal y como fue o habría debido ser" (ibid.). Elio Lodolini argumenta que éste también podría denominarse método objetivo porque, sin importar quién sea el archivista que esté llevando a cabo el proceso de organización de los documentos, el resultado de la clasificación y de la ordenación tendría que ser siempre el mismo.

Podría pensarse incluso en la gestión de documentos - que no administración de archivos- como un método bajo el cual se identifican, organizan, valoran y describen los documentos de archivo. Administrar no es sinónimo de gestionar. El término administración está conformado por el prefijo ad, que quiere decir "hacia" y por ministratio, que proviene a su vez de minister, vocablo que se divide en minus, comparativo de inferioridad, y en ter, que sirve como término de comparación. Magister (magistrado), por ejemplo, indica una función de preeminencia o autoridad, ya que se refiere al que ordena o dirige a otros para el cumplimiento de una función. En cambio, minister quiere decir justo lo contrario, subordinación u obediencia, esto es, el que ejerce una función bajo el mando de otro, servir. La etimología deja ver que la administración supone una función que se desarrolla bajo la orden de un superior. La administración se refiere entonces a un servicio que se presta. La Historia ha demostrado la evolución que el término ha tenido gracias a la aportación que las distintas civilizaciones han hecho para el desarrollo de esta disciplina. En sus inicios, la administración nació y era producto de contar con líderes natos, pero las demandas sociales fueron exigiendo un mejoramiento continuo de los productos, los procesos y las técnicas. Como ciencia social, Wilburg 
Jiménez Castro dice que está compuesta de principios, técnicas y prácticas cuya aplicación a conjuntos humanos permite establecer sistemas racionales de esfuerzos cooperativos a través de los cuales se pueden alcanzar propósitos comunes que de manera individual no se podrían lograr en los sistemas colectivos.

En la obra de Lourdes Münch Galindo y José García Martínez, se citan a dos autores que definen la administración. El primero de ellos es Isaac Guzmán Valdivia, quien la definió como "la dirección eficaz de las actividades y la colaboración de otras personas para obtener determinados resultados" (Münch Galindo, 1995: 33). El segundo es José Fernández Arena, que se refiere a esta disciplina como "la ciencia social que persigue la satisfacción de objetivos institucionales por medio de una estructura y a través del esfuerzo humano coordinado" (1995: 12). Como se observa, la administración es una actividad orientada a la obtención de resultados mediante procesos eficaces y eficientes asumidos por un grupo social y cuyo objetivo es lograr la máxima productividad en las organizaciones.

Hay que recordar que la administración científica, creada por Taylor en 1903, se caracterizaba por enfatizar las tareas realizadas por el obrero, en tanto que la teoría clásica de Fayol, surgida en 1916, se distinguió por prestar mayor atención a la estructura y las funciones de la institución para lograr estándares óptimos de calidad, a través de la puesta en marcha de elementos tales como la planeación, la organización, la dirección, la coordinación y el control. Así, con la administración se pretende que las instituciones logren tener mayores beneficios a través de la instrumentación de mecanismos que le proporcionen rentabilidad.

Este breve recuento es la base para entender que lo que se administran son las instituciones (continente) y no el objeto que administran (contenido), pues en términos archivísticos, se han empleado de manera indistinta los términos gestión y administración para referirse tanto a los Archivos, como a los documentos de archivo. De esta manera, las combinaciones que se pueden encontrar en numerosos textos doctrinarios son gestión de documentos, gestión de Archivos, administración de documentos y administración de Archivos. Este uso indiscriminado del lenguaje no es otra cosa que 
una consecuencia más de la carencia de una terminología uniforme que, lejos de simplificar la ciencia archivística, la complica y entorpece. Estas versiones tan variadas de términos empleados son, además, la derivación y traducción que de manera subjetiva los autores conciben al records management norteamericano y que aún no ha logrado tener una consolidación científica, en contraste con sus campos de actuación, los cuales se encuentran claramente definidos.

Para comenzar a sentar bases terminológicas sólidas, habrá que iniciar diciendo que las acepciones que debieran ser reconocidas son la de gestión de documentos por un lado, y la de administración de Archivos por el otro. Gestionar y administrar no son sinónimos, como ya se mencionó, y tampoco lo son los documentos de archivo y los Archivos.

\section{Administración de archivos}

Administrar, según el diccionario de la RAE, es dirigir una institución; ordenar, disponer y organizar en especial la hacienda o los bienes. La administración implica acciones circunscritas en la racionalización de un objeto y en la rentabilidad del mismo. En este caso, lo que se pretende racionalizar y rentabilizar son los Archivos, por lo que la administración de Archivos será entendida como las acciones llevadas a cabo con el fin de racionalizar los recursos de los Archivos para rentabilizar su existencia. Es una actividad encaminada al buen funcionamiento de los servicios archivísticos y su finalidad es proporcionar a la sociedad la información retrospectiva necesaria para su desarrollo administrativo, económico, social, cinético y cultural en áreas de interés para el Estado y los ciudadanos.

A finales de la década de los ochenta, Olga Gallego y Pedro López A. definieron la administración de Archivos como "una actividad encaminada al funcionamiento óptimo de los servicios de los Archivos" (Gallego Domínguez y López Gómez, 1989: 118). Por su parte, el Diccionario de terminología archivística lo define como "la organización responsable de la aplicación de la política archivística a través de la dirección, planificación y control de los programas establecidos". 
La política archivística es, en palabras de Antonia Heredia, "la determinación sistemática de los recursos administrativos, institucionales y económicos que permitan la satisfacción de los fines y objetivos de los Archivos como respuesta a la demanda de la sociedad" (Heredia Herrera, 1995: 200). Según esta autora española, la administración de Archivos incluye la elaboración de textos legales reglamentarios y normativos; la normalización de formularios; la confección y difusión de estadísticas; la aprobación y publicación de tablas de valoración o calendarios de conservación y seguimiento de su aplicación; la adquisición de documentos; la integración de Archivos en el Sistema de acuerdo con el procedimiento establecido reglamentariamente; el control e inspección de Archivos; la implantación de aplicaciones informáticas y diseños de sistemas de información; la elaboración de planes editoriales; la distribución de recursos económicos y humanos; la planificación del acceso a los puestos de trabajo y de la formación; el equipamiento y mantenimiento de los edificios e instalaciones; los planes generales de reproducción y restauración; la integración en planes de gestión de calidad; la planificación y distribución de subvenciones, y las acciones de cooperación, entre otros aspectos (1995: 45).

En algunos países hispanoamericanos, la administración de Archivos incluye tanto los que son administrativos (trámite, centrales y de concentración), como los que son Históricos. En suma, la administración de Archivos no es otra cosa más que la actividad orientada a la obtención de resultados mediante procesos eficaces y eficientes asumidos por un grupo social y cuyo objetivo es lograr la máxima productividad en una institución archivística. Los procesos a los que se hacen referencia están dados por la denominada gestión de documentos o gestión documental.

\section{Gestión de documentos}

La gestión de documentos es la expresión traducida del records management, reconocido a partir de 1941 en Estados Unidos por la Society of American Archivists (Sociedad de Archivistas Americanos), y supone la atención que se presta a los documentos desde 
que son creados en las oficinas administrativas (archivos de trámite), hasta su eliminación definitiva o su conservación permanente en los archivos históricos a partir de planteamientos de economía y eficacia.

La Records Management Act (Ley de Gestión de Documentos) norteamericana la definió en 1975 como "la planificación, el control, la dirección, la organización, la capacitación, la promoción y otras actividades gerenciales relacionadas con la creación de documentos, su mantenimiento, y eliminación, así como el manejo de correspondencia, formularios, directrices, informes, documentos legibles por máquina, microformas, recuperación de información, ficheros, correo, documentos vitales, equipos y materiales de archivos, eliminación de documentos y records centers $\mathrm{u}$ otras instalaciones de mantenimiento" (Jansó I Sanjuan, 1993: 36).

También en los años setenta, la UNESCO definió el término como "[...] el dominio de la gestión administrativa general con vistas a asegurar la economía y eficacia de las operaciones desde la creación, mantenimiento y utilización, hasta la afectación final de los documentos [...]" (Enríquez, 2001: 16). Esta definición encontró eco en autores como José Ramón Cruz Mundet, Alberch I Fugueras y Antonia Heredia Herrera, así como en el Consejo Internacional de Archivos. Guy Duboscq, por su parte, la definió como "una política de intervención sobre la organización misma de los documentos desde su nacimiento en las oficinas" (Duboscq, 1963: 267). Con una postura menos tradicional pero más certera, Joaquim Borrás la concibió como "el conjunto de operaciones y técnicas relativas a la concepción, al desarrollo, la implantación y la evaluación de los sistemas administrativos necesarios desde la creación de los documentos, hasta su destrucción o transferencia a los archivos" (Borrás Gómez, 2000: 35). Ambas posiciones, la de la UNESCO y la de Borrás, constituyen definiciones que, si bien abarcan casi en su totalidad las edades manifestadas por el ciclo vital de los documentos, a pesar de su importancia, no involucran aspectos relacionados con la conservación y los medios para acceder a ellos cuando se encuentran en una fase inactiva. Con todo ello, la ges- 
tión de documentos pretende evitar la producción irracional de los mismos con el objetivo fundamental de lograr, por un lado, la simplificación de la actividad administrativa de las instituciones y, por otro lado, una adecuada coordinación entre las entidades productoras de documentos y los Archivos que los reciben.

Por su parte, el canadiense Michel Roberge definió la gestión de documentos como "un sistema administrativo compuesto de subsistemas. Ella misma - la gestión de documentos- es un subsistema dentro de otro mayor: la gestión de la información" (Roberge, 2011: 201).

En los últimos años, se habla de la información como un activo que le permite a las organizaciones tener mayores beneficios económicos. En el ámbito de la administración pública, el acceso a la información es un mecanismo democrático que facilita el sistema de rendición de cuentas y que prevé disminuir los índices de corrupción y elevar el nivel económico, cultural y político de la sociedad en general, por lo que ésta - la información- se convierte en un elemento que requiere ser gestionado. Así pues, con el curso de los años, la gestión de la información ha ido ocupando cada vez más una posición privilegiada en la economía de los países a escala internacional. El vínculo que une a la información con los documentos es que mientras aquella es el activo que requieren las instituciones para elevar sus estándares económicos, estos últimos son el vehículo en que la información se ve materializada, por lo que la gestión de una implica la de los otros.

Joaquim Borrás aludía a la gestión de documentos como un conjunto de operaciones y técnicas que van dirigidas a resolver los problemas de sobreproducción documental. Esta idea coincide con la de Ana Duplá cuando al definir el tratamiento documental, lo concibe como el "conjunto de tareas y procedimientos que se aplican a los documentos en cada una de las fases del ciclo vital y que tiene como objetivos organizarlos, conservarlos y hacerlos accesibles, manejables y útiles en sus diversos fines" (Duplá del Moral, 1997: 77). De igual manera sucede cuando al llegar a la entrada gestión de documentos en el Diccionario de terminología archivística, ésta 
remite al de tratamiento documental, el cual define como "el conjunto de procedimientos u operaciones técnicas que, basados en el estudio y análisis de la producción, tramitación, utilización e información contenida en los documentos, tiene como resultado el establecimiento de normas sobre las transferencias, la eliminación y/o conservación permanente y accesibilidad de las series documentales”. Así pues, gestión documental y tratamiento documental son dos conceptos que significan lo mismo. Al hablar de procedimientos u operaciones técnicas, se habla de las actividades de identificar, organizar (clasificar y ordenar), valorar y describir los fondos documentales para su máximo aprovechamiento en cada una de las fases del ciclo vital.

En suma, se puede concluir que la administración de Archivos y la gestión de documentos son dos elementos distintos que de ninguna manera pueden considerarse como sinónimos, ya que mientras la primera atiende a la institución como un ente organizacional que desarrolla funciones específicas, la segunda se dirige a controlar la producción, circulación y uso de los documentos que forman parte de los Archivos, y es esta última la que puede concebirse como un método más de la ciencia archivística.

El Archivo como continente, por tanto, se debe administrar según los elementos que en su momento propuso Fayol en la segunda década del siglo XX y que todavía tienen vigencia: planeación, organización, dirección, coordinación y control. En tanto que los documentos de archivo deben gestionarse en función de las tareas que propone el tratamiento documental o la gestión de documentos consistentes en la identificación, organización (clasificación y ordenación), valoración y descripción de los fondos documentales que se constituyen en el testimonio escrito que da sustento a las funciones cotidianas de una institución. La gestión de documentos, pues, resulta un método cuyo resultado tras la aplicación de sus tareas será siempre el mismo y cuyos principios se tendrían que establecer por cada una de las actividades que lo incluyen.

Además de los métodos de investigación tradicionales, algunos especialistas del ramo se dieron a la tarea de hacer una búsqueda 
más profunda y determinaron que, como consecuencia de la vida actual en donde la tecnología juega un papel destacado, deben considerarse como métodos contemporáneos en el campo de la Archivística los que aparecen en la siguiente tabla:

Tabla 1.

Métodos de investigación utilizados en Archivística

\begin{tabular}{|c|c|c|}
\hline Nombre del método & Definición & $\begin{array}{c}\text { Aplicación en la investigación } \\
\text { archivística }\end{array}$ \\
\hline Construcción de teoría & $\begin{array}{l}\text { Construcción y exposición } \\
\text { sistémica. }\end{array}$ & $\begin{array}{l}\text { Teoría archivística, reflexión y } \\
\text { modelos. }\end{array}$ \\
\hline $\begin{array}{l}\text { Desarrollo de teoría } \\
\text { anclada }\end{array}$ & $\begin{array}{l}\text { Desarrollo de descubrimientos } \\
\text { e hipótesis y desarrollo } \\
\text { de teoría a partir de los } \\
\text { datos de la investigación } \\
\text { interpretativa. }\end{array}$ & $\begin{array}{l}\text { Investigación exploratoria donde } \\
\text { se sabe poco acerca de un } \\
\text { fenómeno en particular. }\end{array}$ \\
\hline Análisis de contenido & $\begin{array}{l}\text { Análisis de contenido visible } \\
\text { como subyacente, latente o } \\
\text { simbólico usando sistemas } \\
\text { de codificación. }\end{array}$ & $\begin{array}{l}\text { Análisis del discurso profesional } \\
\text { para establecer tendencias en la } \\
\text { evolución del pensamiento. }\end{array}$ \\
\hline Análisis del discurso & $\begin{array}{l}\text { Uso de constructos } \\
\text { analíticos para el análisis } \\
\text { histórico de ideas, discurso } \\
\text { en términos de contexto. }\end{array}$ & $\begin{array}{l}\text { Análisis del desarrollo de políticas } \\
\text { o legislación de documentos o de } \\
\text { información. }\end{array}$ \\
\hline Análisis narrativo & $\begin{array}{l}\text { Cuerpo de técnicas discretas } \\
\text { relacionado para examinar el } \\
\text { modo narrativo o retórico. }\end{array}$ & $\begin{array}{l}\text { Análisis del concepto para } \\
\text { mejorar la comprensión del modo } \\
\text { en el uso. }\end{array}$ \\
\hline Análisis conceptual & $\begin{array}{l}\text { Técnica que trata los } \\
\text { conceptos como clases } \\
\text { de objetos, eventos, } \\
\text { propiedades o relaciones. }\end{array}$ & $\begin{array}{l}\text { Exámenes de los Archivos, el } \\
\text { poder y la memoria. }\end{array}$ \\
\hline $\begin{array}{l}\text { Análisis de } \\
\text { conocimiento experto }\end{array}$ & $\begin{array}{l}\text { Obtención y codificación } \\
\text { de conocimiento experto en } \\
\text { esquema. }\end{array}$ & $\begin{array}{l}\text { Análisis y procesamiento de } \\
\text { pesquisas (recuperación de la } \\
\text { información). }\end{array}$ \\
\hline $\begin{array}{l}\text { Análisis de garantía } \\
\text { literaria }\end{array}$ & $\begin{array}{l}\text { Está formada por fuentes } \\
\text { autorizadas, reconocidas } \\
\text { y valoradas por los } \\
\text { practicantes. }\end{array}$ & $\begin{array}{l}\text { Identificación de mandatos } \\
\text { sociales para la gestión de } \\
\text { documentos personales. }\end{array}$ \\
\hline $\begin{array}{l}\text { Análisis de garantía } \\
\text { archivística o } \\
\text { de gestión de } \\
\text { documentos }\end{array}$ & $\begin{array}{l}\text { Se deriva del uso del análisis } \\
\text { de la garantía literaria, en el } \\
\text { desarrollo de una estructura } \\
\text { de clasificación. }\end{array}$ & $\begin{array}{l}\text { Para la evidencia, gestión de } \\
\text { documentos o el desarrollo } \\
\text { de bases de datos. }\end{array}$ \\
\hline
\end{tabular}


La Archivística y la ciencia de la información...

\begin{tabular}{|c|c|c|}
\hline $\begin{array}{l}\text { Diplomática } \\
\text { archivística } \\
\text { contemporánea }\end{array}$ & Mac Neil [sic]. & $\begin{array}{l}\text { Identificación de los requisitos } \\
\text { para conservar documentos } \\
\text { auténticos en sistemas } \\
\text { electrónicos. }\end{array}$ \\
\hline $\begin{array}{l}\text { Etnografía de } \\
\text { la gestión de } \\
\text { documentos/ } \\
\text { archivística }\end{array}$ & $\begin{array}{l}\text { Descripción contextual } \\
\text { y reflexiva sistemática } \\
\text { de culturas y prácticas } \\
\text { individuales. }\end{array}$ & $\begin{array}{l}\text { Estudios de profundidad en } \\
\text { la práctica de gestión de } \\
\text { documentos. }\end{array}$ \\
\hline Etnografía del archivo & $\begin{array}{l}\text { Positivistas buscan las } \\
\text { verdades que subyacen } \\
\text { a la actividad y conducta } \\
\text { humana. }\end{array}$ & $\begin{array}{l}\text { Estudio del rol de las autoridades } \\
\text { y las prácticas archivística. }\end{array}$ \\
\hline $\begin{array}{l}\text { Etnología de la gestión } \\
\text { de documentos/ } \\
\text { archivística }\end{array}$ & $\begin{array}{l}\text { Estudios culturales } \\
\text { comparativos de las } \\
\text { prácticas y creencias } \\
\text { cotidianas. }\end{array}$ & $\begin{array}{l}\text { Gestión de documentos y } \\
\text { radiología. }\end{array}$ \\
\hline Estudio de caso & $\begin{array}{l}\text { Estudio de profundidad de } \\
\text { una situación, institución o } \\
\text { proceso. }\end{array}$ & Gestión de documentos. \\
\hline $\begin{array}{l}\text { Estudio de caso } \\
\text { comparativo }\end{array}$ & $\begin{array}{l}\text { Positivistas lo usan } \\
\text { para probar hipótesis. } \\
\text { Interpretativos comparan } \\
\text { con otros casos para } \\
\text { transferir la comprensión } \\
\text { particular. }\end{array}$ & $\begin{array}{l}\text { Investigación, descripción y } \\
\text { análisis de buenas prácticas } \\
\text { y normas del continuo de los } \\
\text { documentos. }\end{array}$ \\
\hline $\begin{array}{l}\text { Investigación de la } \\
\text { acción }\end{array}$ & $\begin{array}{l}\text { Reflexión crítica basada } \\
\text { en la experiencia de } \\
\text { participación acción. }\end{array}$ & $\begin{array}{l}\text { Proyectos de investigación y } \\
\text { desarrollo con triple hélice. }\end{array}$ \\
\hline Histografía & $\begin{array}{l}\text { Cuerpo de técnicas, teorías } \\
\text { y principios de investigación } \\
\text { y presentación histórica. }\end{array}$ & $\begin{array}{l}\text { Estudio histórico de la evolución } \\
\text { del pensamiento y práctica } \\
\text { continua de los documentos. }\end{array}$ \\
\hline Bibliometría & $\begin{array}{l}\text { Métodos estadísticos, a } \\
\text { menudo automatizados, } \\
\text { para analizar datos } \\
\text { históricos "infometría". }\end{array}$ & $\begin{array}{l}\text { Análisis de prácticas históricas de } \\
\text { gestión de documentos. }\end{array}$ \\
\hline $\begin{array}{l}\text { Análisis sociométrico y } \\
\text { redes sociales }\end{array}$ & $\begin{array}{l}\text { Métodos estadísticos } \\
\text { para analizar relaciones } \\
\text { complejas. }\end{array}$ & $\begin{array}{l}\text { Descripción y análisis de la } \\
\text { interacción. }\end{array}$ \\
\hline Cienciometría & $\begin{array}{l}\text { Métodos estadísticos a } \\
\text { menudo informatizados, } \\
\text { analizar datos. }\end{array}$ & $\begin{array}{l}\text { Identificación de fenómenos de } \\
\text { colegios invisibles. }\end{array}$ \\
\hline $\begin{array}{l}\text { Encuestas y } \\
\text { entrevistas, grupos } \\
\text { focales }\end{array}$ & $\begin{array}{l}\text { Encuestas escritas u orales } \\
\text { diseñadas para producir } \\
\text { datos sistemáticos. }\end{array}$ & $\begin{array}{l}\text { Análisis de las necesidades y } \\
\text { actitudes del usuario. }\end{array}$ \\
\hline
\end{tabular}


Apuntes sobre los fundamentos...

\begin{tabular}{|c|c|c|}
\hline $\begin{array}{l}\text { Análisis de sistemas, } \\
\text { análisis funcional y de } \\
\text { negocio }\end{array}$ & $\begin{array}{l}\text { Análisis y evaluación de las } \\
\text { actividades, procesos y } \\
\text { funciones. }\end{array}$ & $\begin{array}{l}\text { Desarrollo de políticas y } \\
\text { estrategias innovadoras. }\end{array}$ \\
\hline $\begin{array}{l}\text { Análisis de gestión de } \\
\text { documentos }\end{array}$ & $\begin{array}{l}\text { Los métodos y técnicas } \\
\text { para el análisis funcional y } \\
\text { de negocio, como técnicas } \\
\text { analíticas más genéricas. }\end{array}$ & $\begin{array}{l}\text { Construir o adaptar sistemas } \\
\text { en la gestión de documentos y } \\
\text { archivos electrónicos. }\end{array}$ \\
\hline $\begin{array}{l}\text { Análisis de sistemas } \\
\text { archivísticos }\end{array}$ & $\begin{array}{l}\text { Práctica de gestión de } \\
\text { documentos y Archivística. }\end{array}$ & $\begin{array}{l}\text { Identificar el modo en que se } \\
\text { crean } \\
\text { y utilizan documentos. }\end{array}$ \\
\hline $\begin{array}{l}\text { Análisis de procesos } \\
\text { de trabajo }\end{array}$ & $\begin{array}{l}\text { Se utilizan en conjunto } \\
\text { con otros métodos de } \\
\text { investigación. }\end{array}$ & $\begin{array}{l}\text { Comprender los mandatos } \\
\text { sociales } \\
\text { y organizativos. }\end{array}$ \\
\hline $\begin{array}{l}\text { Diseño de sistemas y } \\
\text { desarrollo prototípico }\end{array}$ & $\begin{array}{l}\text { El desarrollo de sistemas } \\
\text { cómo métodos de } \\
\text { investigación. }\end{array}$ & $\begin{array}{l}\text { Desarrollo de tecnologías de } \\
\text { conservación. }\end{array}$ \\
\hline $\begin{array}{l}\text { Diseño interactivo de } \\
\text { sistemas }\end{array}$ & $\begin{array}{l}\text { Tipo de investigación de } \\
\text { desarrollo e ingeniería bajo } \\
\text { ciencia aplicada. }\end{array}$ & $\begin{array}{l}\text { Uso de un prototipo como } \\
\text { artefacto de investigación. }\end{array}$ \\
\hline $\begin{array}{l}\text { Desarrollo de } \\
\text { herramientas }\end{array}$ & $\begin{array}{l}\text { Diseños de investigación a la } \\
\text { aproximación de teorías. }\end{array}$ & $\begin{array}{l}\text { Metadatos de un entorno de } \\
\text { servicio web. }\end{array}$ \\
\hline $\begin{array}{l}\text { Construcción de } \\
\text { modelos }\end{array}$ & $\begin{array}{l}\text { Uso de técnicas formales de } \\
\text { modelado de actividad, etc. }\end{array}$ & $\begin{array}{l}\text { Desarrollo de modelos } \\
\text { conceptuales } \\
\text { y descriptivos. }\end{array}$ \\
\hline $\begin{array}{l}\text { Modelos descriptivos, } \\
\text { modelos conceptuales }\end{array}$ & $\begin{array}{l}\text { Uso de técnicas formales } \\
\text { de modelado de actividad, } \\
\text { entidad, relación, rol. }\end{array}$ & $\begin{array}{l}\text { Describir documentos en su } \\
\text { contexto social, negocio. }\end{array}$ \\
\hline $\begin{array}{l}\text { Modelado, mapeado } \\
\text { y referencias cruzadas } \\
\text { de metadatos }\end{array}$ & $\begin{array}{l}\text { Modelado de mapeado } \\
\text { de series de metadatos } \\
\text { que hacen posible una } \\
\text { descripción y estructuración. }\end{array}$ & Uso de modelado formal. \\
\hline Instalación empírica & $\begin{array}{l}\text { Uso sistemático de } \\
\text { documentos para poblar } \\
\text { modelos para probar } \\
\text { validez. }\end{array}$ & $\begin{array}{l}\text { Modelo formal de metamapas } \\
\text { para hacer posible la traducción. }\end{array}$ \\
\hline
\end{tabular}

Diseño: Anne y McKemish (2008).

Todos estos métodos han surgido paulatinamente para asistir al proceso de construcción de un campo de saber científico propio, específico y delimitado, bajo dos premisas claramente fundamen- 
tadas. La primera, la pausada incorporación de la Archivística a los procesos informativo-documentales y la segunda, el paso del pragmatismo al conocimiento científico del fenómeno archivístico donde los componentes más importantes de la disciplina parecerían ser la consolidación de un lenguaje propio, de la problemática construida y de principios científicos definidos (Vivas Moreno, 2005).

\section{LA FINALIDAD DE LA ARCHIVÍSTICA}

Hay diferentes estudios que han mostrado diversos fines que se le atribuyen a la Archivística como disciplina científica. Hay quienes dicen que lo que busca es un consenso entre los miembros de su comunidad, para lo cual se requiere de la consolidación de una terminología específica (Vivas Moreno, 2005).

Una segunda teoría se relaciona con los que opinan que su finalidad debe ser el almacenamiento de la información para hacerla recuperable para su uso posterior. Es decir, los documentos y la información contenidos deben ajustarse a un servicio que se dirige a las instituciones productoras que tramitan asuntos administrativos o a los ciudadanos en general que requieren satisfacer necesidades culturales específicas. Está claro que hoy más que nunca, el fin de la ciencia archivística es mostrar la información que contiene su objeto de estudio, esto es, los documentos de archivo y los propios Archivos que los contienen, pues, como consecuencia de las recientes políticas públicas encaminadas a la rendición de cuentas, es necesario garantizar el acceso a la información a través de estos materiales archivísticos.

\section{En búsqueda de un consenso para la terminología}

Como ya se mencionó, aún en pleno siglo XXI se sigue dudando de la cientificidad de la Archivística. Las dudas son aún más profundas cuando ni siquiera se ha logrado un consenso para asegurarle un nombre propio, pues se siguen utilizando de manera indistinta los términos Archivonomía, Archivología y Archivística. La apari- 
ción de esta trilogía se debe, como es sabido, a la falta de unificación en su vocabulario, aunque es este último - Archivística- el que ha logrado consagrarse a nivel internacional, a pesar de la presencia que Archivología sigue teniendo, contrario al de Archivonomía, que está cada vez más en desuso.

En México se utilizó por primera vez la voz Archivonomía para definir los estudios técnicos que iniciaron en 1945 en la Escuela Nacional de Bibliotecarios y Archivistas (hoy Escuela Nacional de Biblioteconomía y Archivonomía, ENBA) y, más tarde, en 1952, los de licenciatura. El término permanece hasta el día de hoy.

El término Archivonomía designa a la disciplina que enseña las técnicas de organización y control de los documentos de archivo — como lo denominó Antonia Heredia (2008)_- La etimología del vocablo proviene del griego arjion, y se refiere al edificio de un magistrado, el registro o la notaría pública, el cuartel general: un Archivo. Se compone, además, de nomos, que significa ley, norma o regla y, por último del sufijo ía que se refiere a una cualidad o actividad. La Archivonomía es la disciplina que tiene por objeto el estudio de los Archivos, sus principios teóricos y prácticos y el tratamiento de los documentos que los integran en sus distintas fases. Así pues, se refiere a la actividad pragmática que se realiza en un depósito de documentos -Archivo-.

Por su parte, la Archivología que lucha por no correr la misma suerte que el término anterior, es una palabra utilizada en muchos países de América Latina. Tiene raíces griegas. Se compone de arjion que, como ya se mencionó, se refiere al Archivo y de lógos, uno de los sustantivos que más acepciones tiene, puede remitir a "razonamiento", "argumentación", "palabra", "discurso", "inteligencia", "pensamiento", "sentido" o "tratado". Es decir, es el discurso razonado o tratado en torno al Archivo, esto es, la disciplina que se encarga de su estudio. Ésta se limita al estudio del origen, la formación, la organización, la razón jurídica, el ordenamiento legal y el funcionamiento de los Archivos.

Finalmente, la palabra Archivística quizá fue utilizada por primera vez por Antonio Matilla en la década de los sesenta, quien se refirió a ésta como la ciencia de los Archivos, subsumió la Archivonomía a 
ésta y descartó la Archivología (Matilla Tascón, 1960), aunque hay quienes la consideran como sinónimo de Archivística. Éste ha sido el término que más seguidores ha tenido en diversas latitudes del planeta, incluso diccionarios como el de Terminología archivística remiten a Matilla cuando se busca Archivonomía o Archivología.

A lo largo del tiempo, se han establecido diferentes formas de ver la Archivística; sin embargo, todas ellas confluyen en dos corrientes diferenciadas. La primera tiene que ver con quienes defienden la idea de que la Archivística es una técnica - y niegan con ello su carácter científico-, con el argumento de que su función es la de recoger, custodiar y servir los documentos contenidos en los Archivos. Antonio Ángel Ruiz inicia un artículo diciendo que quizá la función longeva de conservar los documentos en estas unidades documentales ha sugerido que se la ubique en un sentido más práctico que teórico (Ruiz Rodríguez, 1986). La segunda corriente es defendida por aquellos que aseguran que la Archivística es una ciencia - para algunos emergente- con personalidad propia porque presenta principios teóricos universales e inalterables, porque tiene un método propio y porque, además, posee un objeto de estudio definido.

Para comprender mejor lo anterior, habría que comenzar por esclarecer lo que se entiende por técnica y por ciencia. La técnica es un saber cuya misión fundamental no es conocer un objeto en sí mismo, sino mejorar o perfeccionar la realización o producción de un fenómeno, un proceso o una estructura. Se refiere a la manera de hacer las cosas, a diferencia de la teoría que mira exclusivamente al pensamiento. Esta última pugna por un esfuerzo de saber, constituido por elementos tales como método, rigor y comprobación. La ciencia se consagra entonces como un conjunto de teorías y juicios encadenados por las reglas de la lógica y del lenguaje. Habría que preguntarse si la Archivística es en todo caso una técnica o una ciencia. Muchos autores han tratado ya de responder a este cuestionamiento sin llegar aún a obtener una respuesta definitiva. De este modo, nos encontramos ante un abanico de posibilidades que van desde los que se inclinan por defender el carácter pragmático de ésta, hasta los que están convencidos de su cientificidad. 
Autores como Manuel Romero Tallafigo ${ }^{17}$ y Aurelio Tanodi, ${ }^{18}$ entre otros, han defendido la idea de que la Archivística es una técnica porque trata de resolver los problemas de organización documental con soluciones prácticas para lograr que el proceso de acumulación, conservación y servicio de la memoria social funcione con eficacia y economía (Rodríguez López, 2000: 380-381). Inclusive, el archivista croata Aurelio Tanodi le otorgaba un carácter auxiliador de ciencias como la Historia y la Administración. En este sentido, la Archivística basa una parte de su actividad en aspectos técnicos que tienen que ver con la aplicación de un proceso pragmático para gestionar de manera más eficiente la información contenida en los Archivos. Sin embargo, esto no significa que sea una disciplina eminentemente empírica.

En contraste, Theodore Shellenberg, ${ }^{19}$ Antonia Heredia, ${ }^{20}$ Elio Lodolini $^{21}$ y el mismo Antonio Ángel Ruiz, ${ }^{22}$ entre otros más, se

17 Técnica para lograr que el proceso de acumulación, conservación y servicio de la memoria social, asentada en determinados soportes físicos y materiales, permanentes y durables, funcione con eficacia y economía (1997: 27).

18 Disciplina auxiliar o funcional de la administración y la Historia que se refiere a la creación, historia, organización y funciones de los Archivos, y sus fundamentos legales o jurídicos (1961: 3).

19 Ciencia que trata de los Archivos, de su conservación, administración, clasificación, ordenación, interpretación, etc., de las colecciones de documentos que en los Archivos se conservan como fuente de estudio para su conocimiento ulterior y servicio público (1956: 42).

20 Ciencia que estudia la naturaleza de los Archivos, los principios de su conservación y organización, y los medios para su utilización. Es la ciencia de los Archivos, no de los documentos, aunque éstos sean producto integrante de aquellos (1995: 11).

21 A partir de la enunciación del principio de procedencia, la Archivística comienza a surgir como una ciencia, ya que posee principios universalmente válidos para su actuación, así como se comienzan a elaborar investigaciones en torno a estos postulados y se crea una literatura que sustenta su proceder (1993: 158).

22 Ciencia que permite manejar y hacer accesible la información de grandes masas documentales generadas por el quehacer cotidiano de una organización en el desarrollo de sus relaciones sociales, de tal manera que sea posible conocer toda la información que el documento puede proporcionar (1995: 34). 
oponen a la practicidad de la Archivística y defienden su carácter científico bajo el argumento de que estudia la naturaleza de los Archivos, los principios de su organización y conservación y los medios para su utilización. A pesar de que la Archivística asume una función práctica, no se puede menospreciar el hecho de que también parte de premisas racionales, críticas y de rigor científico para lograr sus fines.

Ante el debate acerca de si la Archivística es una técnica o una ciencia, se han encontrado autores que incluso no se decantan por una o por otra, sino que más bien la consideran como parte de los dos aspectos, tal como lo ha expresado José Ramón Cruz ${ }^{23}$ y el Diccionario de terminología archivística. ${ }^{24}$ Qué razón tenía Manuel Vázquez al decir que lo que es un hecho innegable es que la Archivística, como la Medicina, la Arquitectura o la Ingeniería y otras disciplinas de esta naturaleza, constituye una ciencia aplicada, toda vez que su estudio va más allá de un mero ánimo especulativo, antes bien se pone en práctica para servir a sus usuarios (Vázquez Murill, 2004).

\section{CONCLUSIONES}

La Archivística es pues, la ciencia que se ocupa del estudio de los Archivos en sus aspectos tanto teóricos como prácticos, establece principios inalterables y estudia técnicas adecuadas de gestión de documentos y administración de Archivos. De esta manera, vincula las entidades productoras y el conjunto orgánico de documentos por ellas generados a fin de hacer accesible la información almacenada en los fondos documentales a quienes requieran hacer uso de ella. Es la ciencia encargada de gestionar los documentos de archivo a través de:

23 Ciencia emergente. Ciencia por cuanto posee un objeto, un método y un fin (1994: 64).

24 Disciplina que trata de los aspectos teóricos y prácticos de los Archivos, y de su función. 
- La aplicación práctica de procesos que permiten identificar, organizar, clasificar, ordenar, valorar y describir la información.

- La consolidación de principios y métodos teóricos que le permiten elevarla a un nivel científico.

Pero también es la ciencia encargada de administrar los Archivos como unidades documentales que demandan la planificación, el control, la dirección y la organización de sus estructuras físicas y funcionales.

\section{BIBLIOGRAFÍA}

Alberch I Fugueras, R. (2003). Los archivos, entre la memoria bistórica y la sociedad del conocimiento. España: UOC.

Anne, G., y S. McKemmish. (2008). Nuevos métodos de investigación en archivística. Cartagena: 3000 informática.

Bauer, G. (1970). Introducción al estudio de la historia. España: Bosch.

Borrás Gómez, J. (2000). "La integración del sistema archivístico universitario y la gestión documental: oportunidades y ventajas". Boletín Acal, 33-38.

Buonocore, D. (1976). Diccionario de bibliotecología. Argentina: Castellvi.

Cortés Alonso, V. (2007). Archivos de España y América 1. Materiales para un manual. México: FCE.

Cruz Mundet, J. R. (1994). Manual de archivística. Madrid: Fundación Germán Sánchez Ruiperez.

Diccionario de la Lengua Española. Madrid: RAE. Acceso el 29 de enero de 2011 en http://buscon.rae.es.

Diccionario de Terminología Archivística. España: Subdirección General de los Archivos Estatales. Acceso el 29 de abril de 2011 en http://www.mcu.es/archivos/MC/DTA. 
Duboscq, Guy. (1963). Importancia de los archivos modernos para los países en vías de desarrollo. Boletín de la UNESCO para las bibliotecas 17- 5: 267-271.

Duchein, Michel. (1985). Les batiments d'archives construction et équipements. Francia: Archives Nationales.

Duplá del Moral, A. (1997). Manual de archivos de oficina para gestores. Madrid: Marcial Pons.

Enríquez, P. y Rafael Marín López. (2001). Archivos históricos de Granada. España: Ficciones.

Gallego Domínguez, O. y P. López Gómez. (1989). Introducción a la archivística. País Vasco: Servicio Central de Publicaciones del Gobierno Vasco.

Guinchat, C. y Michel Menou. (1983). Introducción general a las ciencias y técnicas de la información y de la documentación. Argentina: UNESCO.

Heredia Herrera, A. (2008). "Gestión de documentos y administración de Archivos". En Antonia Heredia Herrera, Nuevos tiempos, nuevos conocimientos, nueva archivística. Canarias: Anroart. 41-50.

— . (2007). ¿Qué es un Archivo? Asturias: Trea.

_ . (1995). Archivística general. Teoría y práctica. Sevilla: Diputación Provincial de Sevilla.

Jansó I Sanjuan, J. (1993). Gestión de documentos. Definición y análisis de modelos. País Vasco: Gobierno Vasco.

Jenkinson, S. H. (1922). A Manual of Archives Administration. Inglaterra: University of Cambridge.

Jiménez Contreras, E. (1987). "Para un concepto de historia del documento". Boletín de la Asociación Andaluza de Bibliotecarios, 5-18: 5-18.

Lodolini, E. (1993). Archivística: principios y problemas. Madrid: Anabad.

López Yepes, J. (2010). "Prospectiva archivística: nuevas cuestiones, enfoques y métodos de investigación cien- 
tífica". Revista española de documentación científica, 33-2: 201-224. Síntesis.

, (1993). Coord. ¿Qué es documentación? Madrid: ciencias de la información. España: Instituto Nacional de Publicidad.

Martín-Pozuelo Campillos, M. P. (1996). La construcción teórica en Archivística: el principio de procedencia. España: s/e.

Matilla Tascón, A. (1960). Cartilla de organización de archivos. España: s/e.

Mendo Carmona, C. (2004). "Consideraciones sobre el método en archivística". Documenta et instrumenta, 1 : 35-46.

Molina Nortes, J., y V. Leyva Palma. (2000). Técnicas de Archivo y Tratamiento de la Documentación Administrativa. Madrid: Anabad.

Munch Galindo, L. y José García Martínez. (1995). Fundamentos de administración. México: Trillas.

Núñez Fernández, E. (1999). Organización y gestión de archivos. Asturias: Trea.

Otlet, P., y M. D. Ayuso García (1996). El tratado de documentación. Murcia: Editum.

Pernía, H. A. (1990). Diccionario de archivología: términos relativos a la archivología, paleografía, diplomática y materias afines. Venezuela: Archivo General de la Nación.

Rendón Rojas, M. Á. (2011). Bibliotecología, archivística, documentación: intradisciplina, interdisciplina o transdisciplinariedad. México: CUIB-UNAM/ UAEM.

— . (2005). Bases teóricas y filosóficas de la bibliotecología. México: CUIB-UNAM. 
Roberge, M. (2011-) Lo esencial de la gestión documental: Sistema integrado de los documentos analógicos y de los documentos electrónicos. Quebec: Éditions Michel Roberge.

Rodríguez López, M. D. (2000). "La delimitación de la archivística como ciencia”. En I Congreso Universitario de Ciencias de la Documentación. Madrid: Universidad Complutense de Madrid: 261-270.

Romero Tallafigo, M. (1997). Archivística y Archivos: soportes, edificio y organización. Sevilla: S \& C.

Ruiz Rodríguez, A. Á. (1995). Manual de archivística. Madrid: Síntesis.

- . (1986). "La ciencia archivística y la universidad". En boletín de la Anabad. Madrid: Anabad, 103-107.

Shellenberg, T. R. (1956). Archivos modernos: principios y técnicas. México: AGN.

Tanodi, A. (1981). Introducción a la ordenación y clasificación. Santiago de Chile: Programa de Naciones Unidas para el Desarrollo.

. (1961). Manual de archivonomía hispanoamericana: teorías y principios. Córdoba: Universidad Nacional de Córdoba.

Vázquez Murillo, M. (2004). Administración de documentos y archivos: planteos para el siglo XXI. Argentina: Alfagrama.

Vivas Moreno, A. "Archivos y empresas: un consenso ineludible”. La Palabra Clave, 1(1): 40-58.

Vivas Moreno, A. (2005). "La representación de la historia de la archivística como método de investigación: las fuentes indirectas". Ciencias de la información, 36-3: 49-66. 


\title{
Ciência da informação e Arquivologia: áreas do conhecimento?
}

\author{
Angelica Alves da Cunha Marques \\ Programa de Pós-graduação em Ciência da Informação \\ Universidade de Brasília (UnB)
}

En fait, le classement des

connaissances, selon une hiérarchie

des disciplines, n'est que le reflet de

valeurs sociales: quelle est la reine

des sciences? ${ }^{1}$

(Gass, 1972: n7)

\section{CONSIDERAÇÕES INICIAIS}

$\mathrm{E}$ m 1970, acontece, na cidade de Nice, França, um Seminário sobre a Interdisciplinaridade nas Universidades. Organizado pelo Centre pour la Recherche et l'Information dans l'Enseignement (CERI), com a colaboração do Ministério Francês de Educação Nacional, o evento reúne um grupo de pesquisadores em torno do assunto, a fim de analisar se e como a interdisciplinaridade poderia realmente favorecer o ensino e a pesquisa adaptados à evolução do conhecimento da nossa sociedade (Centre pour la Recherche et L'information dans L'enseignement 1972).

1 "De fato, a classificação do conhecimento, segundo uma hierarquia de disciplinas, não é mais que o reflexo de valores sociais: qual é o reino das ciências?" (Gass, 1972: 7, tradução nossa). 
Na mesma década, a Arquivologia dá grandes passos no cenário brasileiro: em 1970, é publicado o Mensário do Arquivo Nacional (MAN), uma espécie de correio de notícias arquivísticas internacionais e nacionais; em 1971, é criada a Associação dos Arquivistas Brasileiros (AAB), que realiza o I Congresso Brasileiro de Arquivologia (CBA), quando é recomendada a definição de um currículo mínimo para os cursos de Arquivologia, que têm a sua criação em nível superior aprovada, no mesmo ano, pelo Conselho Federal de Educação (CFE); em 1974, é fixado o currículo mínimo e a duração para os cursos de Arquivologia em nível superior, pelo CFE; em 1976, é aprovado o quadro de professores do Curso Permanente de Arquivos (CPA) - que funciona no Arquivo Nacional (AN) desde 1960 - e dos cursos avulsos do AN; e em 1977, o CPA é transferido para a Federação das Escolas Federais Isoladas do Estado do Rio de Janeiro (FEFIERJ), atual Universidade Federal do Estado do Rio de Janeiro (Unirio), com a denominação de Curso de Arquivologia, abrindo caminho para outros quinze cursos que a partir daí seriam criados em várias universidades brasileiras. ${ }^{2}$

Desde 2002, realizamos uma extensa pesquisa, mediante um amplo projeto dedicado ao estudo da trajetória de institucionalização e configuração da Arquivologia como disciplina no Brasil, conjugando suas interlocuções internacionais e diálogos com outras disciplinas. Esse projeto é desdobrado em quatro fases: iniciação científica (Cunha 2003), no âmbito do curso de Arquivologia (2002-2003); mestrado (2005-2007) e doutorado (2007-2011) no Programa de

2 Os dezesseis cursos de graduação em Arquivologia brasileiros estão distribuídos nas seguintes universidades: Unirio, Universidade Federal de Santa Maria (UFSM), Universidade Federal Fluminense (UFF), UnB, Universidade Estadual de Londrina (UEL), Universidade Federal da Bahia (UFBA), Universidade Federal do Rio Grande do Sul (UFRGS), Universidade Federal do Espírito Santo (UFES), Universidade Estadual Paulista Júlio de Mesquita Filho (UNESP/Marília), Universidade Estadual da Paraíba (UEPB), Universidade Federal da Paraíba (UFPB), Fundação Universidade do Rio Grande do Sul (FURG), Universidade Federal de Minas Gerais (UFMG), Universidade Federal do Amazonas (UFAM), Universidade Federal de Santa Catarina (UFSC) e Universidade Federal do Pará (UFPA). 
Pósgraduação em Ciência da Informação da Universidade de Brasília (UnB) (Marques 2007; 2011); e, atualmente, estágio pós-doutoral no Brasil e na França (École Nationale des Chartes).

A partir dos resultados das fases já concluídas da pesquisa, observamos que, apesar de a trajetória da Arquivologia ter um viés predominantemente histórico no Brasil, muito em razão da atuação do AN, a sua configuração como disciplina científica se delineia bastante próxima da Ciência da Informação, considerando: os vínculos acadêmico-institucionais dos cursos de graduação; a titulação dos docentes desses cursos; a vinculação das pesquisas com temas arquivísticos no âmbito dos programas de pós-graduação stricto sensu; a classificação da disciplina no âmbito das áreas do conhecimento pelo Conselho Nacional de Desenvolvimento Científico e Tecnológico (CNPq). Em graus variados, esses aspectos retomam os critérios para a caracterização da natureza de uma disciplina propostos por Heckhausen (1972), no evento sobre Interdisciplinaridade, realizado em Nice: domínio material, domínio de estudo, nível de integração teórica, métodos, instrumentos de análise, aplicações práticas e contingências históricas das disciplinas.

Os três primeiros aspectos foram estudados nas três primeiras fases da nossa pesquisa, enquanto o último vem sendo desenvolvido no âmbito do estágio pós-doutoral. Ainda que entendamos que sejam vertentes complementares de um mesmo objeto de estudo, qual seja, a configuração da Arquivologia como disciplina científica, mediante a sua institucionalização e as suas relações interdisciplinares nesse processo, neste capítulo optamos por recortá-lo, apresentando as relações entre a Arquivologia e a Ciência da Informação, mais sob o olhar da primeira do que da segunda disciplina, considerando a nossa formação, titulação e os nossos interesses de pesquisa. $O$ ângulo escolhido remete a uma síntese da atual fase da pesquisa, levando-nos à seguinte questão, condutora deste capítulo: a classificação da Ciência da Informação e da Arquivologia nas tabelas de áreas do conhecimento (TACs), pelo CNPq, reflete as trajetórias históricas e as configurações atuais dessas disciplinas no Brasil?

Evidentemente, não temos a pretensão de responder esta questão, dada a sua complexidade. Entretanto, considerando a relevância da sua reflexão, buscamos pistas para analisá-la, apresentando, 
ainda que não exaustivamente, o histórico da estruturação das áreas do conhecimento no Brasil. Apoiados nas contingências históricas das disciplinas às quais Heckhausen (1972) se refere, bem como nas teorias da classificação e das relações entre disciplinas, retomamos as quatro propostas de TACs do CNPq.

\section{A TEORIA DA CLASSIFICAÇÃO \\ E A CLASSIFICAÇÃO DAS CIÊNCIAS}

A história dos problemas taxonômicos pode ser compreendida em quatro épocas: 1) de Platão e Aristótelis aos grandes taxonomistas do século XVIII, quando as classificações eram hierárquicas e estabelecidas segundo critérios únicos; 2) do século XVIII, quando surgem as classificações hierárquicas pautadas em multicritérios e virtualmente infinitas; 3) do fim do século XVIII ao início do século XIX, com as classificações combinatórias ou de ordens múltiplas cruzadas; 4) e do século XX até nossos dias, com modelos algébricos rigorosos, classificação numérica automatizada e informatizada (Parrochia, 1998).

Numa ampla perspectiva da definição de classificação, temos vários estudiosos da Filosofia, que chegam, inclusive a apresentá-la em dicionários dessa área (Santos, 1963; Abbagnano, 2003; Durozoi e Roussel, 2002), somente para citar alguns exemplos. Conforme a teoria da classificação, esta é a redução da multiplicidade indefinida de seres a um número finito de tipos que representem tudo o que esses seres têm em comum e as relações gerais que os unem. Dessa forma, "Classificar é distribuir ou repartir indivíduos em grupos distintos, a partir de características comuns e de características diferentes" (Liard, s. d.: 127), considerando suas marcas superficiais (variáveis), numa classificação artificial, ou essenciais (permanentes), numa classificação natural. Como bem assinala Liard (134):

Considerados em si mesmos, os tipos que nós encontramos nos diversos estágios de classificação são imagens, não imagens de indi- 
víduos determinadas, mas, se assim pudermos dizer, de imagens gerais, de esquemas, como dizem os estudiosos, nas quais são condensados os traços comuns a toda uma categoria de indivíduos.

Assim, podemos entender a classificação como um processo lógico (Japiassu e Marcondes, 1991; Durozoi e Roussel, 2002), do qual são definidas classes (Japiassu e Marcondes, 1991; Abbagnano, 2003) ou grupos (Santos, 1963), a partir de características comuns dos elementos representados (Japiassu e Marcondes, 1991; Nadeau, 1999).

A exemplo de amplas definições de "classificação", estudiosos da Filosofia também trazem definições para "classe" (Japiassu e Marcondes, 1991; Nadeau, 1999; Abbagnano, 2003). Para os primeiros autores, "Em seu sentido lógico, classe é um conjunto de seres, de objetos ou fatos, em número indeterminado, todos possuindo certas características comuns" (Japiassu e Marcondes, 1991: 51, grifos nossos).

Quanto às perspectivas da classificação, Pombo (1998) apresenta as quatro orientações de classificação propostas por Diemer (1974)

- Ontológica (classificação dos seres): trata do problema da classificação nas ciências (Biologia, Geologia, Cosmologia, Antropologia ou Tipologia psicológica).

- Gnosiológica (classificação das ciências): trata do problema da classificação das ciências, no âmbito da Filosofia da Ciência.

- Biblioteconômica (classificação dos livros).

- Informacional (classificação das informações).

- As duas últimas correspondem, segundo a autora, a uma ciência da classificação, dedicada ao estudo dos sistemas de classificação. Tendo em vista os objetivos da nossa pesquisa, centramo-nos na segunda orientação, que abrange a classificação das ciências.

O pioneirismo da sistematização da classificação do conhecimento é tributado ao italiano Angelo Poliziano, humanista e poeta 
que, em 1941, publica um esquema das relações entre as ciências ou áreas do conhecimento chamado "Panepistemon", iniciando o “'movimento' de elaboração de sistemas de classificação” (Dahlberg, 1979: 353).

Todavia, antes e depois dele, vários outros estudiosos se dedicam a classificar o conhecimento do seu tempo. Dentre eles, podemos mencionar o famoso Francis Bacon, Mario Nizolio, Comte, Ampère, Saint-Hilaire, Spencer, Dilthey, Wundt, Windelband, Rickert, Ostwald, Henry Evelelyn Bliss, Carnap, Ranghanathan e Samurin (Santos, 1963; Dahlberg ,1979; Durozoi e Roussel, 2002; Abbagnano, 2003).

A classificação das ciências do século XIX tem suas raízes na sistemática naturalista do século anterior (Pombo, 1998) e também passa a ser objeto de definição pela Filosofia. "A unidade da ciência funda-se na unidade de seu objeto", que pode ser, segundo Santos (1963: 274), material (concreto) ou formal (aspecto particular do objeto material, que caracteriza a ciência). Nesse sentido, "A variedade do objeto formal permitiu a especialização científica, como também a classificação das ciências" (Santos, 1963: 275).

Abbagnano (2003: 140), por sua vez, distingue os papéis da enciclopédia e das classificações científicas, explicando que:

Enquanto uma enciclopédia é a tentativa de dar o quadro completo de todas as disciplinas científicas e de fixar de modo definitivo as suas relações de coordenação e subordinação, uma classificação das C. tem só o intuito mais moderno de dividir as C. em dois ou mais grupos, segundo a afinidade de seus objetos ou de seus instrumentos de pesquisa.

Independentemente das classes adotadas, Pombo (1998) pontua que toda classificação das ciências possui: um agente classificativo, um mecanismo classificador, um princípio de classificação, uma multiplicidade de fins, elementos finitos, um contexto de classificações precedentes, um produto externo da atividade classificadora. 


\section{ENTRE DISCIPLINAS}

Muitas são as definições e reflexões sobre interdisciplinaridade e suas variações (multidisciplinaridade, pluridisciplinaridade, transdisciplinaridade, etc). No Seminário sobre a Interdisciplinaridade nas Universidades (Nice, 1970), alguns estudiosos definem a interdisciplinaridade de forma ampla, sem estabelecer condições específicas para a sua existência, como Berger (1972) e Jantsch (1972). Outros pesquisadores, para defini-la, já pressupõem a reciprocidade gerada pelos diálogos entre disciplinas: é o caso de Piaget (1972), por exemplo.

Ao longo dos anos, muitos autores vêm transitando entre posicionamentos e definições diversas, sobrepondo e multiplicando denominações em torno das relações entre disciplinas. Para os portugueses, Pombo, Guimarães e Levy (1994: 12), diversos conceitos são construídos com base na "diferente prefixação da palavra disciplinaridade. Nesse sentido, a etimologia do prefixo 'inter' poderia explicar a [...] centralidade e carácter intermédio do conceito de interdisciplinaridade". A comparação dos diferentes graus de relações entre as disciplinas é didaticamente apresentada por esses autores e, por nós, sintetizada:

Quadro 1.

Classificação dos níveis de intensidade de integração entre disciplinas

\begin{tabular}{|c|c|c|}
\hline Definição & Intensidade & Forma de integração \\
\hline Pluridisciplinaridade & fraca & coordenação \\
\hline Interdisciplinaridade & crescente & combinação \\
\hline Transdisciplinaridade & elevada & fusão \\
\hline
\end{tabular}

Fonte: elaboração própria, com base em Pombo, Guimarães e Levy (1994).

A partir dessas definições, gostaríamos de destacar o que nos parece evidente: se são relações entre disciplinas, então estas são, pelo menos inicialmente, distintas. 


\section{ClASSIFICAÇÕES DAS ÁREAS DO CONHECIMENTO NO BRASIL}

Com a primeira grande guerra mundial, há o reconhecimento da eficácia da Ciência \& Tecnologia (C\&T) para a definição das batalhas. Nessa perspectiva, surgem as fundações particulares para incentivo à C\&T, assim como ideias de criação de muitos conselhos de pesquisa, no âmbito de políticas nacionais (Motoyama e Nagamini, 1996: 332-333).

A história do CNPq pode ser contada a partir da década de 1920, quando surge, na Academia Brasileira de Ciências (ABC), a ideia da necessidade de criação de um conselho de pesquisas (Conselho Nacional de Pesquisa e Desenvolvimento Científico e Tecnológico, 1984; Motoyama, 1985; Motoyama e Nagamini, 1996). A instituição recebe o apoio de pesquisadores, cientistas e políticos, que acalentam essa ideia. Contudo, a falta de apoio político e do próprio Estado evidencia a necessidade de articulação entre os políticos e pesquisadores, que enfrentam muitos desafios em torno dos seus objetivos, até a criação do Conselho Nacional de Pesquisas, em 15 de janeiro de 1951, pela Lei $1.310 .^{3}$

A TAC do CNPq tem a sua estrutura de base nesse contexto e passa por atualizações, ao longo do tempo, de acordo com demandas relacionadas à incorporação de áreas não contempladas. A classificação das áreas do conhecimento delinei-se como instrumento de sistematização de informações sobre C\&T, especialmente para o planejamento, a gestão e a avaliação de políticas públicas. Tratando de difícil, complexa e delicada classificação no âmbito de interesses diversos, a organização e representação do conhecimento trabalha com conceitos complexos; envolve gestores, administradores, agências de fomento e de avaliação, sociedades científicas, institutos de pesquisa e a comunidade científica como um todo. Ao abranger a

3 A trajetória histórica do CNPq é detalhadamente apresentada por Motoyama (1985) e Motoyama e Nagamini (1996), Andrade (1998) e Domingos (2004) também a apresentam criticamente. 
comunicação em ciência, a administração de programas de agência de fomento (informação sobre C\&T e não informação de C\&T) e a produção de estatísticas nacionais, a TAC é, assim, um dos instrumentos de sistematização de dados em C\&T. Nesse sentido, as áreas do conhecimento são um elemento referencial, de categorização das agências de fomento, no contexto do ensino, da pesquisa e da inovação (Souza, 2004; 2006; 2008).

Entre 1951 e 1966, o CNPq reconhece sete setores como áreas do conhecimento: Biologia e Ciências Médicas; Agronomia; Química; Física e Astronomia; Matemática; Geologia ou Ciências da Terra; e Tecnologia (Romani, 1982). Em 1966, são concebidos mais dois setores: Veterinária e Ciências Sociais. O setor técnico, por sua vez, deixa de aparecer nessa classificação.

Dez anos mais tarde, o critério para a classificação das áreas do conhecimento passa a corresponder aos 15 comitês assessores. E é nesse ano, em 1976, que o Conselho publica a sua primeira TAC, segundo a qual, "A classificação das Áreas do Conhecimento tem por finalidade permitir ao CNPq e, eventualmente, a outros órgãos e instituições, sistematizar informações sobre o desenvolvimento científico e a formação de recursos humanos para a pesquisa" (Conselho Nacional de Desenvolvimento Científico e Tecnológico, 1978: 3). Nesse documento, a Comunicação (área) abrange as Ciências da Informação (subárea), que tem como especialidades: Sistemas da Informação; Biblioteconomia e Documentação. A Arquivologia não aparece nessa classificação.

Em 1978, essa tabela é atualizada e, em 1982, a segunda TAC do CNPq é publicada, hierarquizando áreas, subáreas e especialidades dentro de cinco grandes áreas (Souza, 2005). Na grande área "Ciências Humanas, Sociais e Artes", a área denominada como "Ciência da Informação, Biblioteconomia e Arquivologia" é contemplada com duas subáreas: Teoria da Informação e Tratamento da Informação. Como especialidades da Teoria da Informação aparecem: Teoria Geral da Informação; Processos da Comunicação; Teoria da Classificação; Representação da Informação; e Métodos Quantitativos, Bibliometria. Como especialidades da subárea Tratamento da Informação: Técnicas de Recuperação da Informa- 
ção; Processos de Disseminação da Informação; e Organização de Arquivos.

Em 1984, é publicada a terceira TAC que, no texto da sua apresentação, enuncia: "A Classificação das Áreas do Conhecimento tem finalidade eminentemente prática, objetivando proporcionar aos órgãos que atuam em ciência e tecnologia uma maneira ágil e funcional de agregar suas informações" (Conselho Nacional de Desenvolvimento Científico e Tecnológico, 1984: s.p.). As áreas e subáreas são rearranjadas em oito grandes áreas. Na grande área "Ciências Sociais Aplicadas", a Ciência da Informação (agora no singular) aparece como área, subdividida nas seguintes subáreas: Teoria da Informação (com as especialidades Teoria Geral da Informação; Processos da Comunicação; e Representação da Informação), Biblioteconomia (com as especialidades Teoria da Classificação; Métodos Quantitativos, Bibliometria; Técnicas de Recuperação da Informação; e Processos de Disseminação da Informação) e Arquivologia (com a especialidade Organização de Arquivos). A Arquivologia é, então, contemplada como subárea da área Ciência da Informação. A Museologia é uma área à parte, sem subdivisões (Conselho Nacional de Desenvolvimento Científico e Tecnológico 1984; Souza 2004; 2005; 2008; Souza e Stumpf, 2009).

Essa versão da TAC passa por duas tentativas de revisão, na década de 1990 e em 2005. ${ }^{4}$ Nesta última, a tabela teria oito grandes áreas, dentre as quais, as Ciências Socialmente Aplicáveis, que, por sua vez, contemplariam a Ciência da Informação, a Biblioteconomia e a Arquivologia como áreas distintas.

4 Em 2005, o CNPq, a CAPES e a Financiadora de Estudos e Projetos (FINEP) compõem uma comissão especial de estudos para propor uma nova TAC, considerando a defasagem da tabela em vigor e a "forte tendência de interdisciplinaridade das áreas do conhecimento". Essa comissão deveria, em sintonia com as tendências internacionais e com a comunidade científica, estudar as profissões com base na Organização Internacional do Trabalho (OIT), mapear os problemas das grandes áreas e definir as bases epistemológicas para a nova tabela (Portaria conjunta do CNPq, CAPES e FINEP, de 2 de março de 2005). 
Entretanto, por diversas razões, essa proposta não se consolida e a tabela em vigor ainda é a de 1984, que possui 9 grandes áreas (Ciências Exatas e da Terra; Ciências Biológicas; Engenharias; Ciências da Saúde; Ciências Agrárias; Ciências Sociais Aplicadas; Ciências Humanas; e Linguística, Letras e Artes; Outros), 76 áreas, 340 subáreas e 867 especialidades, conforme síntese apresentada no quadro 2. Esses quatro níveis de subdivisão são assim definidos: ${ }^{5}$

1) Grandes áreas: "aglomeração de diversas áreas do conhecimento em virtude da afinidade de seus objetos, métodos cognitivos e recursos instrumentais refletindo contextos sociopolíticos específicos".

2) Áreas: "conjunto de conhecimentos inter-relacionados, coletivamente construído, reunido segundo a natureza do objeto de investigação com finalidades de ensino, pesquisa e aplicações práticas”.

3) Subáreas: "segmentação da área do conhecimento (ou área básica) estabelecida em função do objeto de estudo e de procedimentos metodológicos reconhecidos e amplamente utilizados".

4) Especialidades: "caracterização temática da atividade de pesquisa e ensino. Uma mesma especialidade pode ser enquadrada em diferentes grandes áreas, áreas básicas e subáreas”.

5 Informações disponíveis em: <http://www.capes.gov.br/avaliacao/instrumen tos-de-apoio/tabela-de-areas-do-conhecimento-avaliacao $>$. Acesso em 4 ago. 2014. 
Quadro 2.

Estruturação das áreas do conhecimento pelo CNPq (1951-2005)

\begin{tabular}{|l|c|c|c|c|c|c|c|}
\hline Divisões & $\begin{array}{c}1951- \\
1966\end{array}$ & 1966 & 1976 & TAC 1976 & TAC 1982 & $\begin{array}{c}\text { TAC } \\
1984\end{array}$ & $\begin{array}{c}\text { Proposta de } \\
\text { revisão da } \\
\text { TAC (2005) }\end{array}$ \\
\hline Grandes áreas & - & - & - & - & 5 & 81 & 8 \\
\hline Áreas & 7 & 8 & 15 & 42 & 70 & 76 & 94 \\
\hline Subáreas & - & - & - & - & - & 340 & 456 \\
\hline \begin{tabular}{l} 
Especialidades \\
\hline
\end{tabular} & - & - & - & - & - & $867^{2}$ & $\begin{array}{c}\text { Não (lista } \\
\text { alfabética) }\end{array}$ \\
\hline $\begin{array}{l}\text { 1 Depois foi incluída outra grande área "Outros", com 23 itens listados em ordem alfabética } \\
\text { (De Fernandez, 2005 [?]). } \\
2 \text { Á época da publicação da última TAC, as especialidades não foram detalhadas (Conselho } \\
\text { Nacional de Desenvolvimento Científico e Tecnológico 1984). Este número corresponde às } \\
\text { especialidades incorporadas na tabela em 2002. }\end{array}$
\end{tabular}

Fonte: Conselho Nacional de Desenvolvimento Científico e Tecnológico (1978; 1984), Romani (1982), Souza (2004; 2005; 2008), Souza e Stumpf (2009).

\section{ANÁLISE DOS RESULTADOS E CONSIDERAÇÕES FINAIS}

À luz da classificação das ciências e das relações entre as disciplinas, retomamos o histórico da estruturação das áreas do conhecimento, pelo CNPq, por meio das suas quatro propostas de TACs, relacionando a Arquivologia e a Ciência da Informação, em perspectivas de coordenação e de subordinação, conforme quadro 3.

A partir deste quadro, retomamos a questão condutora deste trabalho: a classificação da Ciência da Informação e da Arquivologia nas TACs, pelo CNPq, reflete as trajetórias históricas e as configurações atuais dessas disciplinas no Brasil?

Os diversos modelos de classificação, segundo vários estudiosos, evoluíram, ao longo do tempo, de forma a buscar atender diversas demandas. Dessa maneira, os modelos utilizados atualmente são herdeiros desses aperfeiçoamentos, embora não exista consenso a respeito. Considerando as citações de Liard (s. d.) e Gass (1972), podemos entender que as classificações, inclusive aquelas das ciências 


\section{Quadro 3.}

Configuração da Ciência da Informação e da Arquivologi na estruturação das áreas do conhecimento pelo CNPq (1951-2005)

\begin{tabular}{|c|c|c|}
\hline Datas & Ciência da informação & Arquivologia \\
\hline 1951-1966 & Não aparece & Não aparece \\
\hline 1966 & Não aparece & Não aparece \\
\hline TAC 1976 & $\begin{array}{l}\text { Área: Comunicação } \\
\text { Subárea: Ciências da Informação } \\
\text { Especialidades: Sistemas de Informação; } \\
\text { Biblioteconomia e Documentação; e Outras } \\
\text { (com a indicação especificar) }\end{array}$ & Não aparece \\
\hline TAC 1982 & $\begin{array}{l}\text { Grande área: Ciências Humanas, Sociais e Artes } \\
\text { Área: Ciência da Informação, Biblioteconomia e } \\
\text { Arquivologia } \\
\text { Subáreas: Teoria da Informação e Tratamento da } \\
\text { Informação. } \\
\text { Especialidades da Teoria da Informação: Teoria } \\
\text { Geral da Informação; Processos da Comunicação; } \\
\text { Teoria da Classificação; Representação da } \\
\text { Informação; e Métodos Quantitativos, Bibliometria } \\
\text { Especialidades do Tratamento da Informação: } \\
\text { Técnicas de Recuperação da Informação; Processos } \\
\text { de Disseminação da Informação; e Organização de } \\
\text { Arquivos }\end{array}$ & $\begin{array}{l}\text { Aparece como área, } \\
\text { juntamente da Ciência } \\
\text { da Informação. A } \\
\text { Organização de } \\
\text { Arquivos aparece } \\
\text { como especialidade } \\
\text { da subárea } \\
\text { Tratamento da } \\
\text { Informação }\end{array}$ \\
\hline TAC 1984 & $\begin{array}{l}\text { Grande área: Ciências Sociais Aplicadas } \\
\text { Área: Ciência da Informação } \\
\text { Subáreas: Teoria da Informação, Biblioteconomia } \\
\text { e Arquivologia } \\
\text { Especialidades da Teoria da Informação: Teoria } \\
\text { Geral da Informação; Processos da Comunicação; } \\
\text { e Representação da Informação } \\
\text { Especialidades da Biblioteconomia: Teoria da } \\
\text { Classificação; Métodos Quantitativos, Bibliometria; } \\
\text { Técnicas de Recuperação da Informação; } \\
\text { e Processos de Disseminação da Informação } \\
\text { Especialidade da Arquivologia: Organização } \\
\text { de Arquivos }\end{array}$ & $\begin{array}{l}\text { Aparece como } \\
\text { subárea } \\
\text { da área Ciência da } \\
\text { Informação }\end{array}$ \\
\hline $\begin{array}{l}\text { Proposta } \\
\text { de revisão } \\
\text { da TAC } \\
(2005)\end{array}$ & $\begin{array}{l}\text { Grande área: Ciências Socialmente Aplicáveis } \\
\text { Área: Ciência da Informação } \\
\text { Subáreas: Fundamentos da Ciência da } \\
\text { Informação; Organização do Conhecimento; } \\
\text { Gestão da Informação; Disseminação e Uso da } \\
\text { Informação; Política e Economia da Informação; } \\
\text { e Tecnologias da Informação }\end{array}$ & $\begin{array}{l}\text { Grande área: Ciências } \\
\text { Socialmente Aplicáveis } \\
\text { Área: Arquivologia } \\
\text { Subáreas: Fundamentos } \\
\text { de Arquivologia; } \\
\text { Gestão Arquivística; } \\
\text { Métodos Arquivísticos; } \\
\text { e Arquivologia } \\
\text { Especializada }\end{array}$ \\
\hline
\end{tabular}

Fonte: Conselho Nacional de Desenvolvimento Científico e Tecnológico (1978; 1984), Romani (1982), Souza (2004; 2005; 2008), Souza e Stumpf (2009). 
(as classificações das áreas do conhecimento que nos interessam) são imagens sociais condensadas e representadas em esquemas, logo, redutoras da realidade.

Assim ocorre também com as TACs no Brasil, as quais parecem desempenhar papel mais enciclopédico, mediante a fixação das relações entre as disciplinas, como afirma Abbagnano (2003), do que a divisão científica em grupos, pela afinidade dos objetos e dos instrumentos de pesquisa das áreas do conhecimento, respeitando as singularidades das diversas disciplinas científicas.

A classificação das áreas do conhecimento no Brasil tem, como agentes classificativos, pesquisadores representantes das diversas áreas, que utilizam a hierarquização dessas áreas como mecanismo classificador, segundo princípios de classificação que não nos parecem claros - como, por exemplo, a ordem histórica da constituição e diferenciação das disciplinas; ou a natureza dos objetos estudados, como propõe Pombo (1998)—, tendo fins práticos, ao conjugar disciplinas constituídas e disciplinas em vias de constituição, num contexto de classificações precedentes, do próprio CNPq, gerando esquemas, conhecidos como TACs.

Enquanto na primeira versão da TAC do CNPq (1976), a Arquivologia nem aparece, na segunda versão desse documento (1982), ela é contemplada como uma área, juntamente da Ciência da Informação e da Biblioteconomia. É importante destacar que, nessa classificação verificamos um grande avanço, quando a Arquivologia e a Biblioteconomia passam de especialidades para a denominação de área (embora não tenhamos informações que justifiquem essa emancipação das duas disciplinas). Afinal, tratam-se de campos do conhecimento anteriores à própria Ciência da Informação, que, segundo grande parte dos estudiosos, teria se constituído no contexto do pós-guerra.

Na terceira versão da TAC (1984), que está em vigor, embora a Arquivologia seja contemplada, a sua posição é de subordinação à Ciência da Informação. Verificamos, pois, um retrocesso no reconhecimento da Arquivologia como área do conhecimento, que é redefinido na proposta de revisão da tabela, em 2005, quando a Arquivologia apareceria independente da Ciência da Informação, 
configurando um grande avanço para o reconhecimento político-institucional para a disciplina arquivística.

Mas como essa proposta não se concretiza, entendemos que a classificação atual da Arquivologia, como uma subárea da Ciência da Informação, parece pautar-se muito mais em suas características superficiais do que essenciais. As características essenciais, com base em Liard (s. d.), são aquelas permanentes, invariáveis, que, no caso da Arquivologia, relacionam-se à organicidade dos arquivos, aspecto particular desses conjuntos documentais que são produzidos e acumulados em razão das atividades de pessoas físicas e jurídicas (Arquivo Nacional, 2005; Bellotto, 2014), o qual, por sua vez, singulariza a Arquivologia no mundo científico, especialmente no campo da informação (Marques, 2011), conjugando princípios e métodos particulares dessa disciplina. Portanto, a organicidade é qualidade inerente aos arquivos e não parece comum às informações produzidas em outros contextos, que não sejam, necessariamente, conjuntamente ligadas às atividades de pessoas e instituições, de forma registrada.

Evidentemente, esta particularidade dos arquivos e, consequentemente da Arquivologia, não insula a disciplina, mas multiplica as suas possibilidades de interlocução, conforme constatamos ao longo da nossa pesquisa (Cunha, 2003; Marques, 2007; 2011). Os diálogos da Arquivologia com outras disciplinas, especialmente com a Ciência da Informação, não afetam a sua identidade como disciplina científica: afinal, como apontam Rousseau e Couture, "Autonomia não significa isolamento" (1998: 73). O amadurecimento da disciplina traduziu-se na necessidade de criação dos cursos de graduação e, posteriormente, no desenvolvimento de pesquisas com temáticas arquivísticas nos cursos de pós-graduação stricto sensu. Dessa forma, observamos que os vínculos institucionais da Arquivologia na universidade e a formação do quadro docente dos seus cursos de graduação são aspectos que demonstram as interfaces das suas relações com outras disciplinas, influenciando na sua produção científica e propiciando a afirmação de sua identidade como disciplina científica.

Se a interdisciplinaridade (e suas variações) é configura-se justamente em decorrência das relações entre disciplinas, parece-nos 
evidente que não podemos reduzir a Arquivologia à Ciência da Informação (e vice-versa). Qualquer redução nesse sentido seria um desrespeito à trajetória histórica e à configuração epistemológica dessas disciplinas.

\section{REFERÊNCIAS BIBLIOGRÁFICAS}

Abbagnano, Nicola. (2003). Dicionário de Filosofia. São Paulo: Martins Fontes.

Andrade, Ana Maria Ribeiro de. (1998). "História e fonte para a história do CNPq". En Museu de Astronomia e Artes Afins. Rio de Janeiro: MAST.

Arquivo Nacional. (2005). Dicionário Brasileiro de Terminologia Arquivística. Rio de Janeiro: Arquivo Nacional.

Belloto, Heloísa Liberati. (2014). "O sentido dos arquivos". En I Ciclo de Palestras da Diretoria de Arquivos Institucionais-DIARQ. Belo Horizonte: Universidade Federal de Minas Gerais. Acesso em 29 março 2015 https:// www.ufmg.br/diarq/anexos/wfd_14012774465385cc06bbb48--fala_bellotto.pdf.

Berger, Guy. (1972). "Opinions e realités". En Centre Pour la Recherche et l'Information dans l'Enseignement. L'interdisciplinarité: problèmes de l'enseignement et de recherché dans les universités, 19-74. Paris: OCDE.

Centre pour la Recherche et l'Information dans l'Enseignement. (1972). L'interdisciplinarité: problèmes de l'enseignement et de recherché dans les universités. Paris: OCDE.

Conselho Nacional de Desenvolvimento Científico e Tecnológico. (1978). "Classificação das áreas do conhecimento". Cadernos de Informação em Ciência e Tecnologia 1.

Conselho Nacional de Pesquisa e Desenvolvimento Científico e Tecnológico. (1984). Áreas do conhecimento: classificação. Brasília: CNPq: 55. 
Cunha, Angelica Alves da. (2003). "A pesquisa em Arquivística no Brasil: um estudo da produção científica nos programas de pós-graduação e de iniciação científica e do papel das agências financiadoras". En: Congresso de iniciação científica da UnB, 9, 2003, Brasília. Resumos. Brasília: UnB.

Dahlberg, Ingetraut. (1979). "Teoria da classificação, ontem e hoje". Em Conferência Brasileira de Classificação Bibliográfica. Anais, 352-370. Rio de Janeiro: IBICT.

Domingos, Manuel. (2004). "A trajetória do CNPq". Acervo 17-2:19-40.

Domingos, Manuel e Rosali Fernandez. (2005). Sobre as áreas do conbecimento. Brasília: Fundo CNPq [?].

Durozoi, Gérard e André Roussel. (2002). Dicionário de Filosofia. Campinas: Papirus.

Gass, J. R. (1972). Prefacio de Centre pour la Recherche et l'Information dans l'Enseignement. L'interdisciplinarité: problèmes de l'enseignement et de recherché dans les universités, 7-8. Paris: OCDE.

Heckhausen, Heinz. (1972). "Discipline et interdisciplinarité". En L'interdisciplinarité: problèmes de l'enseignement et de recherché dans les universités, 83-90. Paris: OCDE.

Jantsch, Erich. (1972). "Vers l'interdisciplinarité et la transdisciplinarité dans l'enseignement et l'innovation". En L'interdisciplinarité: problèmes de l'enseignement et de recherché dans les universités, 98-125. Paris: OCDE.

Japiassu, Hilton e Danilo Marcondes. (1991). Dicionário básico de Filosofia. Rio de Janeiro: Zahar.

Liard, Louis. Logique. Paris: Masson, s.d.

Marques, Angelica Alves da Cunha. "Os lugares da Arquivologia no campo da informação". Ciência da Informação 41-1 (2013):109-123. 
. (2011). "Interlocuções entre a Arquivologia nacional e a internacional no delineamento da disciplina no Brasil". Tese Doutorado em Ciência da Informação. Brasília: Universidade de Brasília.

configuraçâo espaços e os diálogos da formação e configuração da Arquivística como disciplina no Brasil. Dissertação Mestrado em Ciência da Informação. Brasília: Universidade de Brasília.

Motoyama, Shozo. (1985). "A gênese do CNPq". Revista da Sociedade Brasileira de História da Ciência 2: 27-46.

Motoyama, Shozo e Marilda Nagmini. (1996). "CNPq e CNRS: duas histórias numa perspectiva comparada”. En Amélia Império Hamburger et al., A ciência nas relações Brasil-França (1850-1950), 331-359. São Paulo: Editora da Universidade de São Paulo/ FAPESP.

Nadeau, Robert. (1999). Vocabulaire technique et analytique de l'epistemologie. Paris: Puf.

Parrochia, Daniel. (1998). "Classifications, histoire et problèmes formels”. Bulletin de la Société Francophone de Classification. Paris, n. 10.

Piaget, Jean. (1972). L'epistemologie des relations interdisciplinaires. En L'interdisciplinarité: problèmes de l'enseignement et de recherché dans les universités, 131-144. Paris: OCDE.

Pombo, Olga. (1998). "Da classificação dos seres à classificação dos saberes". Revista da Biblioteca Nacional de Lisboa, 2:19-33.

Pombo, Olga; Henrique M. Guimarães e Teresa Levy. (1994). A interdisciplinaridade: reflexão e experiência. Lisboa: Texto.

Romani, Jacqueline Pitangui. (1982). "O Conselho Nacional de Pesquisas e Institucionalização da Pesquisa Científica no Brasil". En Universidades e instituições científicas no Rio de Janeiro, Simon Schwartzman, ed., 137-167. Brasília: CNPq. 
Rousseau, Jean-Yves e Carol Couturr. (1998). Os fundamentos da disciplina arquivística. Lisboa: Publicações Dom Quixote.

Santos, Mário Ferreira dos. (1963). Dicionário de Filosofia e Ciências Culturais, vol.1. São Paulo: Matese.

Souza, Rosali Fernandez de. (2008). "A Ciência da Informação como área do conhecimento e de fomento no CNPq". En Encontro Nacional de Ensino e Pesquisa em Informação, 8, Salvador, 2008. Anais. Salvador.

. (2006). "Organização e representação de áreas do conhecimento em Ciência e Tecnologia: princípios de agregação em grandes áreas segundo diferentes contextos de produção e uso da informação". Encontros Bibli: Revista Eletrônica de Biblioteconomia e Ciência da Informação $1^{\circ}$ sem (2006). Accesado em 29 de maio de 2017 em https://periodicos.ufsc.br/index. php/eb/article/view/1518-2924.2006v11nesp1p27/384.

- (2005). Tabelas de áreas do conbecimento: proposta de metodologia do trabalho de revisão. Brasília: CNPq.

- . (2004). "Áreas do conhecimento". DataGramaZero: Revista de Ciência da Informação, 5-2.

Souza, Rosali Fernandez de e Ida Regina Chitto Stumpf. (2009). "Ciência da Informação como área do conhecimento: abordagem no contexto da pesquisa e da Pós-graduação no Brasil”. Perspectivas em Ciência da Informação, 14: 41-58. 


\title{
Más allá de lo inmediato: hacia la fundamentación de la Archivística. Reflexiones finales.
}

\author{
Miguel Ángel Rendón Rojas \\ Instituto de Investigaciones Bibliotecológicas y de la Información, UNAM
}

nalizar la relación de la Archivística con la Ciencia de la in-
formación documental exige en menor o mayor manera
realizar una exploración epistemológica de ambas disciplinas, es decir, indagar sobre su ser, lo que traducido a nuestra propuesta de fundamentación de una disciplina significa preguntarnos por sus fundamentos filosóficos - ontológicos, gnoseológicos, antropológicos, axiológicos-, teóricos, lógicos, metodológicos y extrateóricos (Rendón Rojas, 2005: 45-53).

Así pues, al emprender un estudio epistemológico, se tiene la intención de encontrar algunas ideas que arrojen nuevas luces sobre la identidad y comprensión de la ciencia que se analiza, además, si esa disciplina científica tiene relación directa con una aplicación práctica, se ayudará a mejorar la profesionalización en esa área del conocimiento, ya que se podrán identificar las tareas específicas que se deben ejecutar y los entrecruces necesarios con otras disciplinas para realizar esas actividades; sin embargo, hay que ser conscientes de los límites que se deben respetar para no entrometerse en lo que le compete a otros o que los otros no invadan terrenos propios. En el caso concreto que nos ocupa, una reflexión epistemológica de la Archivística, las expectativas no cambian, por lo que esperamos que nuestro trabajo deje entrever caminos que 
conduzcan a elucidar la identidad de esta disciplina y su relación con otras disciplinas informativo-documentales.

Considero necesario realizar dos observaciones previas. En primer lugar, podemos decir que una reflexión de tipo epistemológico posee un carácter eminentemente racional, argumentativo y metódico, pero debemos estar conscientes de que también existen otros factores cuya naturaleza no es precisamente racional que pueden obstaculizar, frenar, sesgar o manipular el proceso de análisis y tienen un papel significativo en la obtención de resultados. He denominado a esos factores que poseen un carácter eminentemente subjetivo extraepistemológicos (Rendón Rojas, 2009). Entre éstos se encuentran los sentimientos, las emociones, incluso los gustos de los miembros de la comunidad epistémica; los intereses políticos, económicos, profesionales, laborales, sindicales, personales y, por qué no decirlo, en ocasiones inclusive egoístas; las tradiciones de investigación, de división del trabajo, de usos lingüísticos, así como también modas intelectuales o tendencias mercadotécnicas. Es indispensable tener presentes estos factores para estar alertas ante su presencia, tener la posibilidad de discernirlos y otorgarles la importancia que les corresponde para no sobrevalorarlos ni reconocerlos como principios epistemológicos; de esta manera, seremos lo más objetivos posibles.

En segundo lugar, se debe dejar en claro que la epistemología no es una ciencia normativa, no proporciona preceptos a seguir para hacer ciencia, pues no es una ciencia de la escuela positivista que al aplicar el método científico, obtenga resultados verdaderos que deban seguirse sin objeción. Quizá haya quienes tienen la expectativa de encontrar una respuesta final a todas las preguntas sobre el ser y la fundamentación de la ciencia sometida al análisis epistemológico, esperan que se levante el velo de las dudas, ambigüedades, errores, malos entendidos, lo que a su vez propiciará que se ponga fin a las múltiples controversias y se llegue a un acuerdo total.

Sin embargo, debemos recordar que la epistemología entendida como filosofía de la ciencia está inserta dentro de la naturaleza filosófica que consiste no en tener "posesión" del conocimiento, sino "amor" (que nunca será posesión) por la sabiduría, por lo que 
se encuentra en búsqueda continua. De esta manera, siempre existirán diversos enfoques, corrientes y escuelas. Sin embargo, considero que pese a la diversidad de puntos de vista, si estos son justificados y se es coherente con las consecuencias a las que nos conducen, tarde o temprano se encontrarán "elementos mínimos comunes" sobre los cuales será posible establecer un diálogo entre esos diferentes enfoques o corrientes y construir consensos y una comunidad epistémica. En este capítulo final, que sirve al mismo tiempo a manera de conclusiones y reflexiones finales, me permito esbozar algunas ideas que conciernen a hacia dónde apunta la relación de la Archivística con la Ciencia de la información documental y algunos principios de los cuales es necesario partir.

Una idea rectora en este análisis epistemológico es alejarnos del concepto de ciencia positivista que reclama la necesidad de aplicar el método científico de una manera muy reduccionista que reconoce un sólo método que es empírico, matemático y lógico, y que asigna a la ciencia la función de descubrir leyes: "Una ciencia es una disciplina que utiliza el método científico con la finalidad de hallar estructuras generales (leyes) [...] las disciplinas que no pueden utilizar el método científico no son ciencias [...]" (Bunge, 2000: 14). La ley científica es "una afirmación acerca de una relación universal invariable, de una conexión causal entre dos o más variables. Además de que el objetivo de toda investigación científica es la formulación de dichas leyes" (Harold, 1963: 97).

De manera contraria, yo parto de la tesis de que no existe sólo un método científico empírico, matemático y lógico, sino que existen otros métodos (semiótico, hermenéutico, fenomenológico, histórico, entre otros) que se aplican de acuerdo a la realidad que se estudia (física, social, formal, humana, psicológica, cultural, etc.). Asimismo, reconozco que la ciencia no sólo tiene el objetivo de descubrir leyes, como las ciencias naturales que son ciencias nomológicas, sino que en ocasiones también pueden tener como objetivo llegar a la comprensión del mundo, como las ciencias sociales y humanas, las ciencias del espíritu que menciona Dilthey, o las ciencias ideográficas de Windelband; no por el hecho de no descubrir leyes universales dejan de ser ciencias. 
Simultáneamente, nos apartamos de la idea kuhniana que menciona la necesidad de la existencia de un solo paradigma aceptado por la comunidad científica para que un conjunto de conocimientos sea considerado como ciencia. En las ciencias sociales y humanas, pueden coexistir diversos enfoques, corrientes y escuelas como consecuencia de la naturaleza de los conocimientos y las realidades estudiadas. En efecto, el mundo humano, cultural, de sentidos, posee un carácter multifacético, complejo y puede ser interpretado de diferentes maneras.

Lo anterior tampoco significa caer en el relativismo y aceptar la diferencia a expensas de la identidad, lo subjetivo en sacrificio de lo objetivo. La multiplicidad tiene un límite y un fundamento: la realidad misma. Ella nos proporciona la objetividad necesaria, el primer acorde para construir la sinfonía de sentidos cuyo único límite es no traicionarla.

Una segunda idea eje en este estudio epistemológico consiste en la convicción de que una ciencia posee un cuerpo teórico integrado por conceptos, enunciados, teorías y la relación existente entre ellos, por lo que los elementos concretos, particulares, contingentes y pragmáticos no pueden formar parte de una teoría y menos aún servir como principios o fundamentos de ella. En una disciplina práctica como la Archivística, la Bibliotecología y la Documentación, existe el gran peligro de querer utilizar objetos concretos en lugar de conceptos en la construcción de su campo científico, de clamar por normas de acción en lugar de por relaciones entre las propiedades de las cosas para fundamentar dicha ciencia. Los objetos concretos también son contingentes, pueden mudar sus características en el tiempo, lugar o condiciones, lo cual, de hecho, ha sucedido, principalmente por la influencia de las tecnologías de la información, que ha provocado una crisis en la disciplina.

Uno de los ejemplos de esta crisis es el concepto de "documento", que antes se equiparaba con lo que se tenía a la mano, un papel manuscrito o impreso. Cuando dejó de serlo para pasar a ser un objeto electrónico, causó gran revolución, inclusive se escucharon voces que anunciaban un cambio de paradigma. En el caso que nos ocupa, no está del todo claro cómo los objetos concretos 
(archivo y fondos documentales) pueden servir de objeto de estudio de la Archivística.

En el marco de la Museología, algunos autores han afirmado la imposibilidad epistemológica de que las instituciones se conviertan en un objeto de estudio de las correspondientes disciplinas. Así por ejemplo, Tomislav Sola escribió:

Are we indeed speaking exclusively about institutions? [...] museo$\operatorname{logy}$ is not a science of museums, just as clearly as Moby Dick is not a manual on whaling [...] In the theatre, which has a longer history, nobody calls an actor or stage director a "theatrologist" (Sola, 1992: 13-14).

Una argumentación semejante sostiene Mensch (1992: s.p.) en su tesis doctoral sobre metodología de la Museología, en el capítulo IV "Objeto de conocimiento" donde escribe: "The often used analogy is that pedagogics is not the science of the school and medicine not the science of the hospital". Por su parte, el checo Zbyněk Zbyslav Stránský (2005: 111) expresa una idea semejante al hablar también sobre la imposibilidad de que el museo sea el objeto de estudio de la Museología: "Me he referido a este respecto a otros campos, por ejem. [sic] la Pedagogía, que tampoco es la ciencia de la 'escuela' o la Teatrología la ciencia 'de teatro"' (Stránský, 2005: 111). ${ }^{1}$ Estela Morales Campos también ha recurrido a esa analogía (medicina-hospital, pedagogía-escuela) pero en el ámbito de la Bibliotecología para resaltar la limitación de esa visión en la que la biblioteca se convierte en un objeto de estudio de esa ciencia (Rendón Rojas, 2014).

La institución es un organismo social que cumple ciertas finalidades que la sociedad le encomendó. Dichas finalidades son satisfacer las necesidades que los individuos presentan en el proceso de su existencia y son "necesidades" porque sin ellas esa existencia se empobrece o sucumbe, y por el contrario, al satisfacerlas, se desarrolla. Entre esas necesidades podemos enumerar, por ejemplo,

1 Odkazoval jsem v této souvislosti i na jiné obory, např. pedagogiku, která také není vědou "o škole" nebo teatrologie vědou "o divadle". 
las educativas, políticas, sanitarias, económicas, religiosas, de información, entre otras; para atenderlas, surgen instituciones educativas (escuelas, universidades, institutos, etc.), instituciones políticas (partidos, presidencia, congreso, electorales, de acceso a la información, etc.), instituciones de salud (hospitales, policlínicas, etc.), instituciones económicas (bancos, instituciones financieras, fondos monetarios, etc.), instituciones religiosas (iglesias de diferente credo) e instituciones de información (agencias informativas, bibliotecas, archivos, museos) encargadas de cubrir las necesidades correspondientes. En esas instituciones, ocurren por antonomasia los fenómenos que las ciencias estudian, incluso puede ser que históricamente hayan nacido en ellas, pero no se identifican con ellas, sus objetos de estudio las rebasan.

Sin embargo, no podemos afirmar que dicha confusión sea exclusiva de las disciplinas informativo-documentales. Existen otras áreas del conocimiento que también tienen el problema de confundir su objeto de estudio con una institución o inclusive un establecimiento concreto. Por ejemplo, en las dependencias educativas de la Universidad Autónoma del Estado de Morelos (UAEM) encontramos la "Facultad de Farmacia", en la cual se ofrece la licenciatura en Farmacia, así como la Maestría y el Doctorado en Farmacia (Universidad Autónoma del Estado de Morelos, 2016).

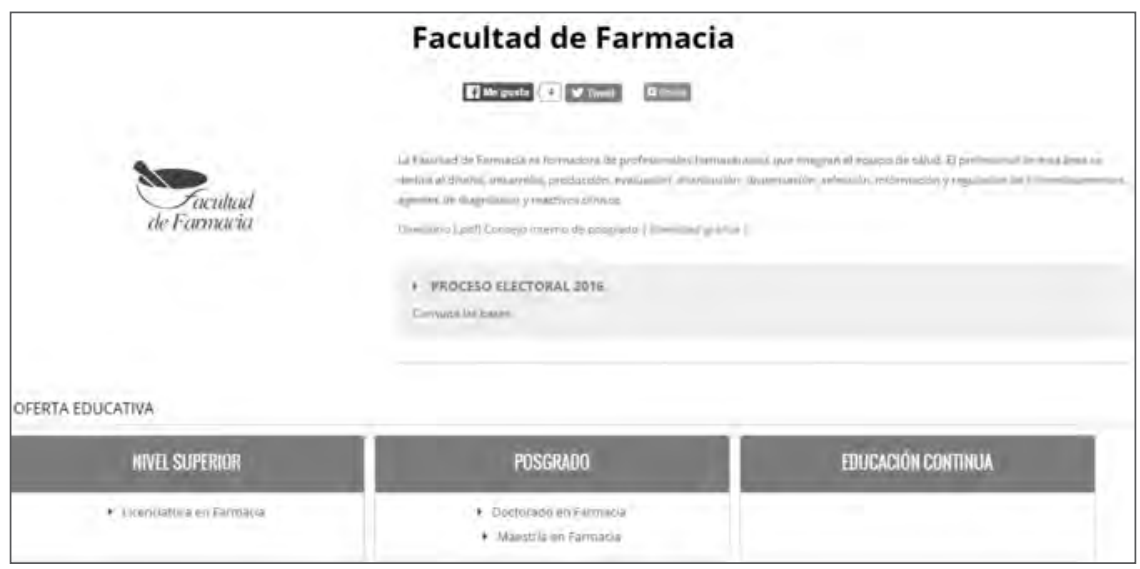


Para evitar una crisis cada vez que se presente un cambio en los objetos concretos que se toman como sustitutos de herramientas teóricas, se debe teorizar sobre un campo de estudio, construir abstracciones, idealizaciones que estén libres de la contingencia característica de los objetos individuales. Así pues, se plantea la necesidad de mudarse de una ontología de primer nivel donde existen objetos concretos, singulares, contingentes, a una ontología de segundo nivel donde habiten objetos abstractos, generales y necesarios, es decir, ideas, conceptos, formas de pensamiento, categorías y modelos.

Simultáneamente, los principios que se busquen para fundamentar la disciplina no deben consistir en normas: "respetar el orden original", "estar disponibles para la consulta", sino en características objetivas de los objetos y las relaciones que se originan con ellas. Desde un punto de vista epistemológico, las normas no son principios sino que dependen de enunciados asertorios. En efecto, una regla de acción: "Haz esto así" tiene validez en cuanto se fundamenta en ciertas relaciones entre objetos o propiedades de los objetos, por lo que Husserl indicó que detrás de toda disciplina práctica hay una disciplina teórica (Husserl, 1985: 60-65). La práctica indica cómo hacer una actividad o acción, la teoría explica por qué seguir los pasos que se ordenan conduce a un resultado positivo o, por el contrario, por qué no seguirlos hace incorrecta una acción. De esta manera, en el caso del principio de procedencia, la pregunta a contestar es por qué se debe respetar ese orden, por qué los fondos documentales conforman una unidad orgánica indivisa.

Cuando nos hemos adentrado al estudio epistemológico del campo informativo documental, hemos descubierto que diversos campos de conocimiento tienen en su centro de atención a la información, desde ingenierías como Computación, de Telecomunicaciones y Cibernética, hasta ciencias eminentemente sociales como el Periodismo, la Publicidad, y la Comunicación; ciencias naturales como la Física y la Genética; ciencias humanas como la Lingüística y la Filología, u otras que por el momento no incluyo en alguna clasificación de las ciencias como la Archivística, Bibliotecología, Ciencia de la información, Documentación y Museología. 
Sin embargo, aunque genéricamente se habla de "información", un análisis más detallado de esa realidad nos muestra que ese fenómeno no es el mismo en todas las esferas. En el mundo físico y tecnológico, tienen lugar fuerzas que poseen velocidad, aceleración y dirección; ondas y campos electromagnéticos, partículas subatómicas, moléculas, enlaces químicos, nucleótidos, circuitos, señales, entre otras muchas propiedades que se interrelacionan de manera sintáctica, es decir, independientemente de sus significados o uso. En las ciencias sociales y humanas (Comunicación, Publicidad, Periodismo, Lingüística, etc.), tenemos la intervención del sujeto, el lenguaje y la comunicación, encontramos información semántica con sentido y significado, así como su aspecto pragmático, que concierne al uso, la interpretación y la intencionalidad que se le otorga. Finalmente, en las últimas disciplinas -Archivística, Bibliotecología, Ciencia de la información, Documentación y Museología-, encontramos semejanzas que nos mueven a agruparlas en una clase especial ya que todas ellas, además de encontrarse en el campo humano y social, de manejar la información de manera sintáctica, semántica y pragmática, de su elemento comunicativo, poseen una intencionalidad común: la información es un bien en cuanto que se le observa como un objeto que satisface necesidades denominadas "necesidades de información" a través de ofrecerla en documentos dentro de una institución informativa documental gracias a la actividad de un profesional de la información documental. Por consiguiente, la información tiene valor de uso, y en una sociedad mercantilista obtiene un valor de cambio cuya manifestación fenoménica es el precio. ${ }^{2}$

Por todo ello, esas disciplinas se pueden designar como informativas documentales, y mientras es posible distinguir la diferente naturaleza de otras áreas de conocimiento que tienen que ver con la

2 Lo mismo sucede al analizar el concepto, por ejemplo, de "documento" o "fuente de información" en diferentes ciencias. Los rasgos distintivos de ese concepto no son los mismos en Criminalística, Periodismo, Etnografía, Antropología, Historia o las disciplinas informativo-documentales, aunque es posible encontrar semejanzas en cómo se concibe dentro de éstas últimas. 
información, entre las disciplinas informativas documentales existe lo que hemos llamado "parentesco de familia" (Rendón Rojas, 2011: 84).

Durante mi trabajo de fundamentación de la Bibliotecología, donde utilicé un enfoque que denominé realismo dialéctico hermenéutico (Rendón Rojas, 2013: 279-281), por un lado llegué a la conclusión de que esa disciplina debe ser comprendida no de manera tradicional, limitada al campo del fenómeno bibliotecario, sino de manera amplia, como el estudio del fenómeno informativo documental y, por otro lado, trabajé siguiendo la propuesta de Lakatos (1983) sobre los Programas de Investigación Científica (PIC), donde el núcleo duro del programa de investigación científica de la Bibliotecología se encuentra en el Sistema Informativo Documental (SID), el cual está compuesto por la información, el documento, el usuario, la institución informativa documental y el profesional de la información documental, las interrelaciones entre esos elementos, además de que su origen y funcionamiento está en dependencia directa con la satisfacción de las necesidades de información documental de los individuos (Rendón Rojas, 2005: 160-173).

En diferentes documentos, he repetido cada elemento del SID. De manera muy resumida, lo repetiré para no mandar a los lectores a consultar otras obras. Concebimos la información como un ente ideal, abstracto, que está presente en los sujetos y es producto de la estructuración e interpretación de símbolos realizadas por ellos. La forma (categoría filosófica que denota un modo de ser de las cosas) codificada en los símbolos, pasa a estar en el intelecto por lo que, en este caso, el prefijo in de la palabra in-forma-tio denota lugar, modo, movimiento. Así pues, la información es más que los datos interpretados, resultaría más correcto decir que es la interpretación de los datos (datos interpretados $\neq$ interpretación de datos). Por su parte, el documento es la objetivación de la información por un autor que la codifica en símbolos y los fija en un soporte. El documento es construido expresamente para serlo y permitir la desobjetivación de la información en el proceso de lectura. Asimismo, el documento en esta área de conocimiento tiene la característica de que es trabajado por el profesional de la infor- 
mación documental, quien lo coloca en un lugar determinado dentro del SID, de forma que agrega información adicional al documento inicial que salió de la mano del autor. Así pues, debido a la naturaleza ideal de la información, afirmamos que ésta no se encuentra de manera "actual" sino potencial en el documento (entendiendo "acto" y "potencia” de manera filosófica), éste se actualiza cuando el sujeto interpreta sus símbolos y reconstruye la información que el autor codificó, aunque en ocasiones puede obtener no sólo una copia de la información original, sino la suya propia con un sentido adicional. Con respecto al usuario, lo conceptualizamos como el sujeto que por su estructura ontológica, esto es, por su forma de ser, presenta necesidades de información que le permiten desarrollar su ser. La institución informativa documental es la institución social creada con la encomienda de proporcionar las condiciones necesarias para satisfacer necesidades de información documental. Por último, el profesional de la información documental es el sujeto que con su actividad proporciona las condiciones para que el usuario pueda ingresar al mundo de la información y de esta manera satisfacer sus necesidades de información.

Ahora bien, si dirigimos nuestra mirada hacia la Archivística, podemos constatar que comparte los mismos elementos del núcleo duro de la ciencia que estudia el fenómeno informativo documental. En ella también tienen lugar la información, los documentos, los usuarios, la institución informativa documental y el profesional de la información documental. Por lo tanto, tiene una ontología común (objetos compartidos) con las disciplinas informativo-documentales. También presenta una dinámica semejante pues el flujo de la información también existe (generación, recolección, representación, procesamiento analítico-sintético, organización, almacenamiento, búsqueda, recuperación, diseminación y uso de la información), además de que comparte otros procesos afines como el comunicativo, la gestión informativa documental, la administración, entre otros que atañen a todas las disciplinas informativo-documentales.

Sin embargo, si no queremos caer en un reduccionismo simplista, no obstante que descubrimos elementos comunes, también re- 
conocemos que cada una de esas disciplinas tiene una forma específica de vincularse con lo general. Por ejemplo, en Archivística la información continúa siendo ese ente abstracto construido por el sujeto al estructurar e interpretar los símbolos plasmados en un documento. Pero es una información con propiedades distintas a las que nos conducen, por ejemplo, un libro, un artículo, una obra de consulta, un objeto de museo. La información que concierne a la Archivística recrea, rememora o refiere un hecho, un acontecimiento o una actividad; en general, un estado de cosas. De lo anterior se sigue que el documento archivístico es la fijación en símbolos de ese tipo de información y, si es legítimo, la información que se construye a partir de él permite formar enunciados que resultarán verdaderos, de ahí su característica de ser un testimonio y una prueba. Estrictamente hablando, la información no es verdadera ni falsa, son ideas, sentidos, significados; lo que es verdadero o falso son los enunciados que se construyen con esas ideas, sentidos, significados.

Otro aspecto distintivo de la Archivística es la manera de tratar el conjunto de documentos al organizarlos. No obstante que la Bibliotecología y la Archivística clasifican y organizan sus documentos, cada una lo realiza con criterios diferentes. Como ya es sabido, los principios de procedencia, respeto de los fondos y orden original ocupan un lugar central en el tratamiento de los fondos documentales de los archivos, mientras que para la Bibliotecología los principios rectores son la clasificación de las ciencias y la división de clases por áreas temáticas. Esa diferencia de acercamiento práctico a la realidad la podemos comprender con ayuda de una comparación en el área de la medicina: Tanto un cirujano del hígado como un neurocirujano del cerebro, cursó estudios de Medicina y ambos tienen un mismo título general, pero ambos saben que no pueden actuar de la misma forma al intervenir uno u otro órgano, que el hígado es capaz de regenerarse y por eso se puede hacer un injerto, y no así el cerebro porque las neuronas no tienen esa capacidad de regeneración. Sería una verdadera ineptitud que al intervenir el cerebro se le tratara como si fuera hígado. De la misma manera, es un total desconocimiento querer organizar un fondo de archivo 
con criterios bibliotecológicos. Podemos representar con la siguiente figura esa convergencia en el núcleo duro y la diversidad en el tratamiento específico de cada disciplina informativa documental (Rendón Rojas, 2011: 83): ${ }^{3}$

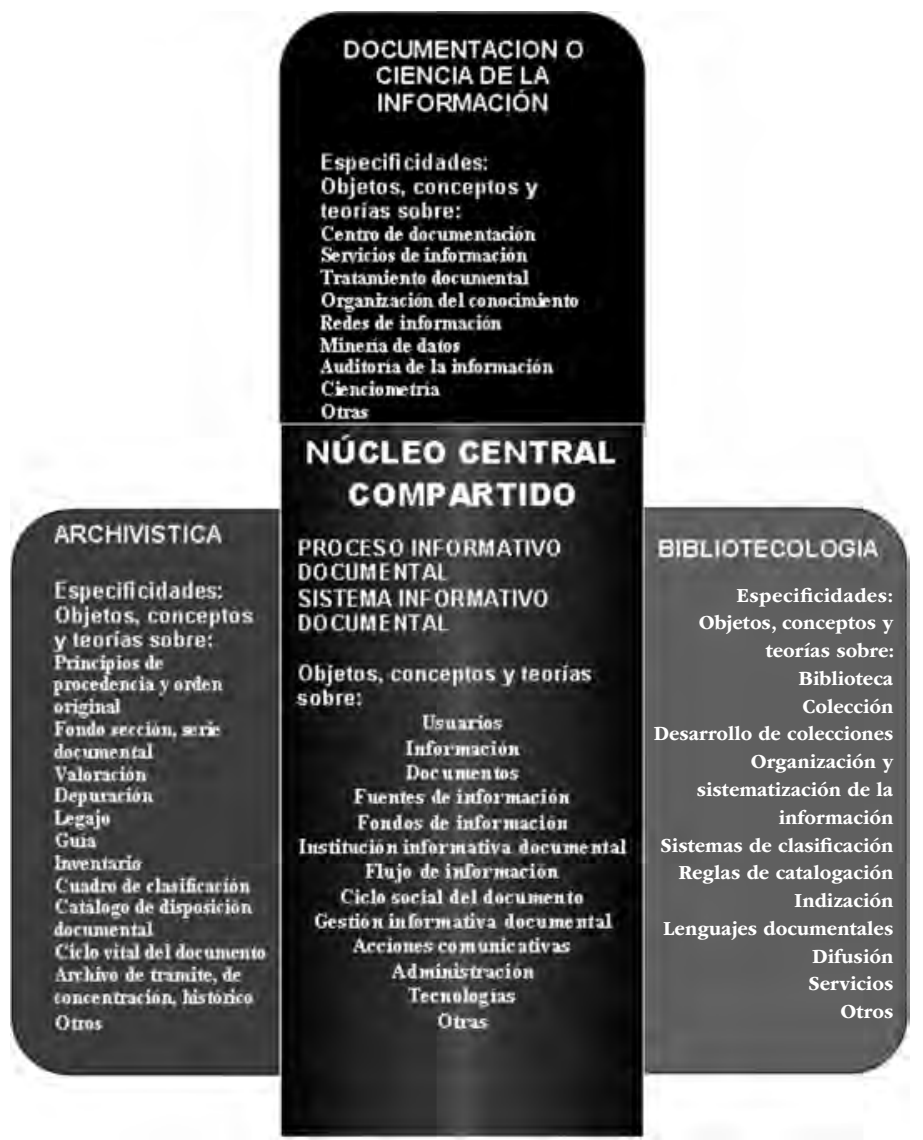

3 Otros autores como Araujo (2011), Silva y Ribeiro (2008) u organizaciones internacionales como la UNESCO (1987) o Cook por encargo de la UNESCO (1986) también ven el proceso de armonización de las disciplinas documentales sin unificar metodologías. 
Es necesario recalcar que, al igual que los cirujanos pueden explicar basados en conocimientos de fisiología, citología, bioquímica, genética, etc., por qué deben tratar de diferente manera al cerebro y al hígado, los bibliotecólogos y archivistas deben conocer las razones teóricas por las cuales no pueden actuar de la misma manera en la organización de colecciones bibliotecarias o fondos de archivos. En los últimos años, una pista de esas razones las han ido exponiendo pensadores posmodernos, principalmente filósofos como Derrida (1997) y Foucault (1990), quienes han señalado la correlación entre la memoria, el poder y el ser. Otra línea interesante a seguir es el correlato entre lenguaje, ser y tiempo, que lleva resonancias heideggerianas.

Ahora bien, como consecuencia de la imposibilidad de que los objetos concretos o la institución sirvan de objeto de estudio de la disciplina y de su característica de compartir el núcleo duro del programa de investigación científica de la ciencia de la información documental se desprende, desde mi punto de vista, el hecho de que la Archivística estudie el proceso informativo documental (flujo y ciclo social de la información) dentro del sistema informativo documental que tiene como elementos el Archivo (como institución informativa documental), los fondos documentales (como documentos) con su ciclo vital, que implica la creación, la organización, la conservación, la disposición y el servicio (las últimas cuatro actividades son realizadas por el profesional de la información documental) con la finalidad de satisfacer las necesidades de información de usuarios de archivos.

En otro tema dentro de este análisis, el trabajo de Angélica Marques sobre las relaciones de la Ciencia de la información y la Archivología con base en las Tablas de Áreas del Conocimiento que elaboró el Conselho Nacional de Desenvolvimento Científico e Tecnológico de Brasil, nos llevó a la idea de realizar una pesquisa similar sobre el lugar que ocupan las ciencias informativo-documentales en el imaginario de la institución encargada de dirigir la política nacional sobre la ciencia y tecnología en México: el Consejo Nacional para la Ciencia y Tecnología (Conacyt), además de la visión que los investigadores de esa área tienen sobre su perte- 
nencia a dicha área de conocimiento. Por supuesto que esta investigación no fue tan detallada ni tiene cortes cronológicos como la realizada por la doctora Marques, sólo tomó en cuenta la clasificación actual de las áreas de evaluación y disciplinas de conocimiento que el Conacyt presenta.

La posibilidad de descubrir el lugar de las ciencias informativodocumentales tanto en la ubicación que le asigna el Conacyt en su clasificación de las ciencias, como en el sentir de los investigadores de su identidad disciplinar, aún si no están de acuerdo con la clasificación que les otorga el Conacyt, existe en virtud de que al llenar la solicitud de ingreso al Sistema Nacional de Investigadores (SNI) del Conacyt, se indica:

F. La solicitud electrónica cuenta con siete secciones: "Datos Para la Evaluación", "Consideraciones", "Adscripción", "Producción", "Productos Relevantes", "Anexos" y "Finalizar". En la Sección "Datos Para la Evaluación”, seleccione el área del conocimiento en la que desea ser evaluado e indique su disciplina, sub disciplina $y$ especialidad de investigación. Es responsabilidad del solicitante verificar que el área de conocimiento elegida sea la adecuada para evaluar su solicitud; después del envío de la solicitud, no se podrán realizar cambios (Sistema Nacional de Investigadores 2016, 4.1) [El resaltado en cursivas es mío].

Es decir, se puede indicar la disciplina en la que se realiza la investigación, pero no su ubicación dentro de un campo de conocimiento. Esto último es algo dado que no se puede elegir, ya fue establecido por el Conacyt, por lo cual, al seleccionar la disciplina y subdisciplina de investigación, automáticamente se acepta el lugar que el Conacyt asigna dentro de su cuadro clasificatorio; sin embargo, el área de conocimiento en la cual se desea ser evaluado, sí se puede elegir libremente según los criterios propios de cada investigador. 
Para indicar la disciplina de investigación, el Conacyt en primera instancia ofrece la siguiente tabla de campos de conocimiento: ${ }^{4}$

\begin{tabular}{|c|c|}
\hline Ex 100 & hy 10 (1-27 de 27 (D) Uithen \\
\hline \multicolumn{2}{|c|}{ Area de ConocimientoDescr. Campo de Conocimiento } \\
\hline 110000 & LOGICA \\
\hline 120000 & MATEMATICAS \\
\hline 210000 & ASTRONOMIA Y ASTROFISICA \\
\hline 220000 & FISICA \\
\hline 230000 & QUIMICA \\
\hline 240000 & CIENCIAS DE LA VIDA \\
\hline 250000 & CIENCIAS DE LA TIERRA Y DEL COSMOS \\
\hline 260000 & CIENCIAS DE LA SALUD \\
\hline 310000 & CIENCIAS AGRONOMICAS Y VEIERINARIAS \\
\hline 320000 & MEDICINA Y PATOLOGIA HUMANA \\
\hline 330000 & CIENCIAS DE LA TECNOLOGIA \\
\hline 510000 & ANTROPOLOGIA \\
\hline 520000 & DEMOGRAFIA \\
\hline 530000 & CIENCIAS ECONOMICAS \\
\hline 540000 & GEOGRAFIA \\
\hline 550000 & HISTORIA \\
\hline 560000 & CIENCIAS JURIDICAS Y DERECHO \\
\hline 570000 & LINGÜISTICA \\
\hline 580000 & PEDAGOGIA \\
\hline$\underline{590000}$ & CIENCIAS POLITICAS \\
\hline 610000 & PSICOLOGIA \\
\hline 620000 & ARTES Y LETRAS \\
\hline 630000 & SOCIOLOGIA \\
\hline 640000 & CIENCIAS DE LA OCUPACION \\
\hline 710000 & ETICA \\
\hline 720000 & FILOSOFIA \\
\hline 810000 & PROSPECTIVA \\
\hline
\end{tabular}

4 Ésta y las siguientes tablas son tomadas de la página del Conacyt que aparecen cuando se sube en línea el Currículum Vitae Única (CVU) de un investigador que desea realizar un trámite en esa dependencia estatal. El acceso no es público: http://registros.main.CONACYT.mx/psp/REGCYT/EMPLO YEE/REGCYT/C/CYT_CVU_CONVOCATORIA.CYT_APP_CVUGRL. GBL?FolderPath=PORTAL_ROOT_OBJECT.CVU.CYT_APP_CVU_GRL_GBL \&IsFolder=false\&IgnoreParamTempl=FolderPath\%2cIsFolder. 
Ahora bien, si elegimos el área 590000, correspondiente al campo de conocimiento de las Ciencias políticas, se despliegan las siguientes disciplinas:

\section{CONACYT}

\section{Consultar Disciplina}

Área de Conocimiento: 590000

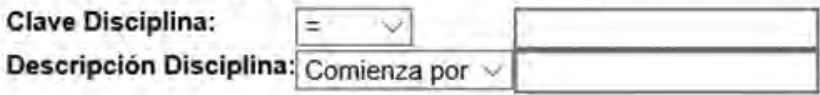

Consultar Borrar Gancelar Cansulta Básica

\section{Resultados de Búsqueda}

\section{Clave DisciplinaDescripción Disciplina}

590100

590200

590300

590400

590500

590600

590700

590800

590900

591000

591100

$\underline{599900}$

RELACIONES INTERNACIONALES

POLITICAS SECTORIALES

IDEOLOGIAS POLITICAS

INSTITUCIONES POLITICAS

VIDAPOLITICA

SOCIOLOGIA DE LA POLITICA

SISTEMAS POLITICOS

POLITICA TEORICA

ADMINISTRACION PUBLICA

OPINION PUBLICA

BIBLIOTECONOMIA Y ARCHIVONOMIA

OTRAS ESPECIALIDADES EN MATERIA DE CIENCIAS POLITICAS

De esta manera descubrimos, curiosamente, que Biblioteconomía y Archivonomía aparecen con la clave 591100, como disciplinas de las Ciencias políticas. Finalmente, dentro de la Biblioteconomía y Archivonomía se despliegan algunas subdisciplinas: 


\section{Consultar Subdisciplina}

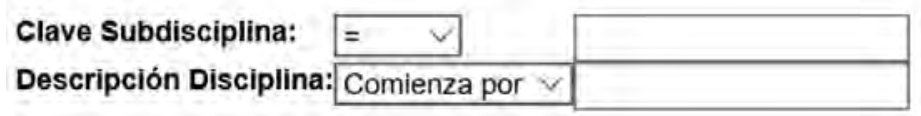

\begin{tabular}{l|l|l|l|l|l|} 
Consultar & Borrar & Cancelar Consulta Básica \\
\hline
\end{tabular}

\section{Resultados de Búsqueda}

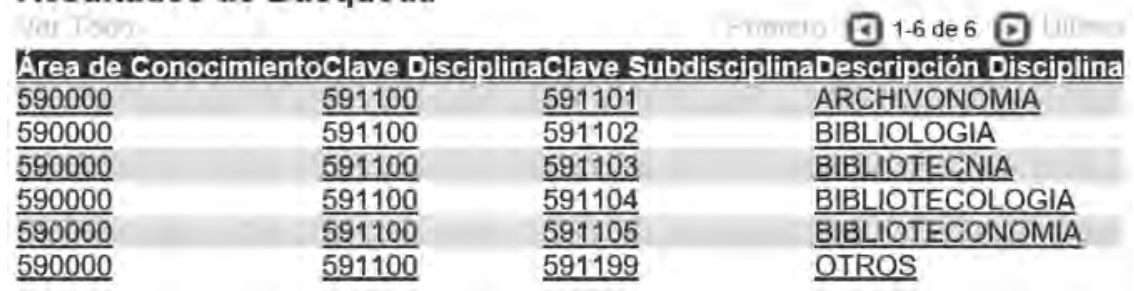

Donde podemos observar que se encuentran, entre otras, 591101 Archivonomía y 591104 Bibliotecología.

De esta manera, en la clasificación del Conacyt, la Bibliotecología y la Archivonomía son disciplinas de las Ciencias políticas y éstas, a su vez, son parte de las Ciencias sociales. Como ya lo mencionamos, el investigador tiene la posibilidad de elegir el área de evaluación en la que desea ser incluido, lo que bien podría ser interpretado como el área a la que éste considera que pertenecen las investigaciones que realiza. El Conacyt presenta ocho áreas:

I. Física, Matemáticas y Ciencias de la Tierra

II. Biología y Química

III. Medicina y Ciencias de la Salud

IV. Humanidades y Ciencias de la conducta

V. Ciencias Sociales y Económicas

VI. Biotecnología y Ciencias agropecuarias

VII. Ciencias de la ingeniería

VIII. Investigación multidisciplinaria 
Por su relevancia para este trabajo, proporcionamos la descripción de las áreas IV, Humanidades y Ciencias de la Conducta y V, Ciencias Sociales y Económicas. Dentro de la primera, Humanidades y Ciencias de la Conducta, se encuentran investigaciones sobre Educación, Antropología física, Arqueología, Estética, Etnohistoria, Filología, Filosofía, Historia, Arquitectura y Urbanismo, Psicología, Literatura, Lingüística y disciplinas afines. Por su parte, el área Ciencias Sociales y Económicas incluye investigaciones sobre Sociología, Antropología social, Demografía, Comunicación, Derecho, Etnología, Economía, Administración, Políticas públicas y Administración privada, Ciencias Políticas, Relaciones internacionales y disciplinas afines (Sistema Nacional de Investigadores, 2012).

Si, como acabamos de comprobar, en esa clasificación la Biblioteconomía y Archivonomía pertenecen a las Ciencias políticas y éstas a su vez se incluyen en las Ciencias sociales, cabría esperar que los investigadores de esas disciplinas informativo documentales optarían como área para ser evaluados la V, pero la realidad muestra que no siempre ocurre de esa manera. En ocasiones se elige, como lo muestran los siguientes datos tomados de una solicitud de ingreso o permanencia en el SNI, ${ }^{5}$ el área IV:

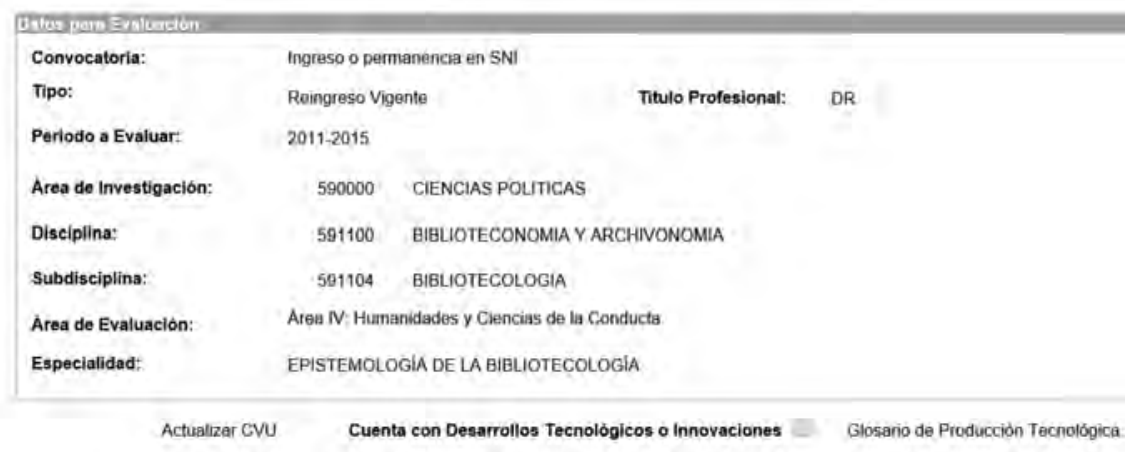

5 El acceso no es público: http://registros.main.CONACYT.mx/psp/REGCYT/ EMPLOYEE/REGCYT/c/CYT_CVU_CONVOCATORIACYTSNI_CONV_CMP. GBL?FolderPath=PORTAL_ROOT_OBJECT.CYT_CVUCONVOCATORIA. CYT_SNI_CONV_CMP_GBL_1\&IsFolder=false\&IgnoreParamTempl=Folder Path\%2cIsFolder. Acceso en marzo de 2016. 
Más aún, el anterior ejemplo no es un caso aislado, la gran mayoría de los investigadores pertenecientes a la disciplina Biblioteconomía y Archivonomía ha elegido el área IV como área de evaluación. En efecto, como lo muestra el directorio de investigadores vigentes hasta 2015 del Sistema Nacional de Investigadores, dentro de la disciplina 591100, Biblioteconomía y Archivonomía, encontramos que hay 36 investigadores, de los cuales veintiocho pertenecen al área de evaluación IV, Humanidades y Ciencias de la Conducta, o sea, el $77.77 \%$, mientras que ocho de ellos, es decir, el $22.22 \%$, eligieron el área $\mathrm{V}$.

Por otra parte, como la disciplina es dual, es decir, incluye simultáneamente a la Bibliotecología y la Archivística - Archivonomía en su terminología-, podemos distinguir las clases que incluyen a quienes optaron como subdisciplina la 591104, Bibliotecología, es decir, se consideran bibliotecólogos; a los que eligieron la 591101, Archivonomía, que se ven a sí mismos como archivistas; a los que decidieron pertenecer a ambas simultáneamente porque consideran que trabajan tanto en una como en otra $y$, finalmente a quienes prefirieron la opción 501199, "Otros".

De acuerdo con el anterior criterio de diferenciación de ese universo, encontramos que de los académicos que pertenecen a la disciplina 591100, Biblioteconomía y Archivonomía, veintisiete investigadores, o sea, el 75\%, trabajan en el área de Bibliotecología; cinco académicos, el $13.88 \%$, investigan la Archivonomía; tres investigadores, el $8.33 \%$, consideran investigan las dos disciplinas, y un investigador, el $2.77 \%$, eligió como subdisciplina "Otros".

Entre los que eligieron la Bibliotecología como subdisciplina de investigación, la tendencia es clara: veinticuatro investigadores, lo que equivale a un $88.88 \%$, optaron por el área de evaluación IV, mientras que sólo tres investigadores, el 11.11\%, eligieron como área de evaluación el área V. Con respecto a los archivistas, descubrimos que esa relación se invierte: quienes escogieron el área $\mathrm{V}$ son mayoría dentro de esa clase. Si tomamos en consideración los cinco investigadores que tienen a la Archivonomía como subdisciplina, tres de ellos, es decir, el 60\%, eligieron el área V como área de evaluación, mientras que los otros dos, el 40\%, optaron por el 
área IV. Por otro lado, de los investigadores que tienen como subdisciplinas a la Biblioteconomía y a la Archivonomía simultáneamente, dos, el 66.66\%, eligieron como área de evaluación el área V y uno, el 33.33\%, optó por el área IV. Finalmente, quien optó por "Otros" como la subdisciplina donde se inserta el tema de su investigación, eligió el área IV como su área de evaluación, lo que en porcentajes significa que el $100 \%$ se encuentra en esa área IV y el 0\% en el área V (Sistema Nacional de Investigadores, 2016b).

Sin embargo, los datos numéricos anteriores deben ser tomados con cautela. En todo momento, se debe de estar alerta a variables extrañas que intervienen siempre que se trabaja con estadísticas en un tema donde se mide la actividad de sujetos. En primer lugar, es necesario considerar que esa clasificación del Conacyt no es del todo confiable. Parece más una acción burocrática que epistemológica, una salida para colocar las ciencias informativo-documentales en alguna clase porque no se sabe bien a bien dónde ubicarlas. No se tiene un documento que exponga los criterios que se siguieron para realizar tales divisiones de los campos de conocimiento. En segundo lugar, las decisiones de los investigadores para elegir un área de evaluación no siempre se desprenden de una reflexión sobre la identidad de su disciplina, sino de seguir la línea marcada por el Conacyt dada en la clasificación que ofrecía. Gracias a la oportunidad que se tuvo de entrevistar a algunos investigadores del área, se pudo constatar esa variable. El razonamiento era el siguiente: si la Bibliotecología y la Archivística ya aparecen como Ciencias Sociales en la clasificación del Conacyt, entonces, para ser consecuentes y no contradecir esa visión, se elegía el área V, Ciencias sociales y económicas, como área de evaluación.

Una tercera variable a considerar, también descubierta en las entrevistas que se tuvieron con los investigadores del área, es que en ocasiones simplemente no se tenía conocimiento de que existía la posibilidad ofrecida por el programa de elegir el área de evaluación, por lo que elegían la opción que el sistema desplegaba por default, la cual, también curiosamente, no era el área V, como era de esperarse, sino el área IV. Es por eso que se debe tomar con cuidado el alto número de investigadores que se encuentran en el 
área IV ya que, si bien algunos de ellos lo están, no fue por una decisión propia, sino porque no cambiaron la opción que aparecía inicialmente. Inclusive se constataron situaciones en las que no se tenía clara la diferencia entre el campo del conocimiento donde se ubica la disciplina y el área de evaluación a la que se desea pertenecer, por lo que aparecía una discrepancia entre lo que el investigador afirmaba y lo que el directorio del SNI mostraba. Se encontraron casos en los que el investigador aseguraba en la entrevista que pertenecía al área $\mathrm{V}$ porque "no dan opción en la solicitud" pero en el directorio del SNI aparecía inscrito en el área IV. En esos casos, no podría afirmarse con certeza si el investigador pertenece al área IV por convicción o por no cambiar la opción.

Por otro lado, debemos tomar en cuenta que el número de casos que se consideran para establecer los porcentajes y las relaciones es bajo, por lo que se debe tener cuidado de no absolutizar esos resultados. Por ejemplo, en lo concerniente a quienes declararon que investigan como subdisciplina "Otros" dentro de Biblioteconomía y Archivonomía. En ese caso, fue sólo un individuo quien eligió el área IV para ser evaluado, por lo que se concluye que el 100\% pertenece al área IV y el $0 \%$ al área V, lo que es cierto, pero con un sólo caso, el análisis no está del todo completo.

Tomando en consideración lo dicho anteriormente con las debidas reservas, en general podemos afirmar que la mayoría de los que investigan Biblioteconomía y Archivonomía se inscriben dentro del área de las Humanidades. Si diferenciamos a los que investigan Bibliotecología de los que estudian a la Archivonomía, observamos que en el área de Bibliotecología la mayoría se inclina por el área de Humanidades y la minoría por las Ciencia sociales, pero en Archivonomía la situación cambia: la mayoría se inscribe en Ciencias sociales. Lo que sí queda claro es que en la tabla de clasificación del Conacyt, las dos disciplinas, Archivística y Bibliotecología, se encuentran en una relación de paridad, ambas cosubordinadas con respecto a las Ciencias políticas, una visión con la que unánimemente no se concuerda en absoluto.

Para concluir y recapitular, propongo distanciarnos de concepciones en las que se recurre a objetos concretos y aspectos mera- 
mente pragmáticos para acercarse y desarrollar la Archivística. Desde ese enfoque, llegará un momento de estancamiento teórico y se producirá un giro hacia lo procedimental que otras disciplinas como la Computación o la Administración bien podrían cumplir. Por lo tanto, es indispensable investigar la parte teórica y metateórica de ese campo de conocimiento para que desde esa posición se esté en condiciones de justificar las normas, los principios y los procedimientos que se desprendan.

Al mismo tiempo, propugnamos por un acercamiento epistemológico a la Archivística que nos libere de los prejuicios que el positivismo impuso en la visión de lo que debe ser una ciencia al equiparar todo el conocimiento científico al de las Ciencias naturales. Por lo anterior, no concebimos que una ciencia deba ser necesariamente empírica o que tenga que utilizar la cuantificación para sustentar sus resultados; tampoco que siempre deba descubrir leyes o que posea un único paradigma. El conocimiento científico según nuestra propuesta, en ocasiones utiliza otros métodos (hermenéutico, fenomenológico, semiótico, entre otros) para justificar sus resultados; cuando se estudian la realidad humana y sus creaciones, difícilmente se descubren leyes, más bien, el conocimiento va dirigido a la comprensión; en la Ciencias humanas y sociales, no existe un único paradigma, sino que se pueden presentar y defender diferentes corrientes o escuelas que evidencian diferentes enfoques para estudiar un fenómeno. Pero esas particularidades no convierten a las Ciencias sociales y humanas en no-ciencias; lo esencial es que tengan un objeto de estudio determinado, un aparato teórico con el cual estudiarlas y una metodología rigurosa que permita justificar sus conocimientos.

Asimismo, hemos observado una divergencia en la manera de concebirse a sí mismos de los archivistas (también de los bibliotecólogos) y constatado que no existe un acuerdo o consenso dentro de la comunidad epistémica correspondiente. ¿Realmente hay una diferencia en la forma de ser y de verse entre los archivistas y los bibliotecólogos?, ¿los primeros son más sociales y los segundos más humanistas? De todo lo anterior, se desprende la necesidad de continuar realizando un estudio epistemológico sobre la Archi- 
vística, encontrar sus fundamentos - filosóficos, teóricos, lógicos, metodológicos, extrateóricos-sobre los que descansa.

Por supuesto, siempre encontraremos a quienes privilegian acciones prácticas realizadas con eficiencia y eficacia. El país y el mundo, argumentan, necesitan resolver problemas de organización de archivos y atención de usuarios, problemas que se resuelven con profesionistas altamente calificados y competentes en las aplicaciones de técnicas, procedimientos y seguimiento de normas establecidas, y no con divagaciones filosóficas o búsquedas teóricas que les parecen vacías. A ellos, únicamente les podemos indicar que siendo conscientes del ser, es más fácil actuar de acuerdo con él, sólo con conocimiento de la meta es posible planear el camino para llegar a ella. La máxima socrática "conócete a ti mismo" sigue siendo válida para las disciplinas científicas.

\section{BIBLIOGRAFÍA}

Araujo, Carlos Alberto. (2011). "Condições teóricas para a integração epistemológica da Arquivologia, Biblioteconomia e Museologia na Ciência da Informação". InCID: Revista de Ciência da Informação e Documentação, 2:19-41.

Bunge, Mario. (2000). La investigación científica. México: Siglo XXI.

Cook, Michael. (1986). Guidelines on Curriculum Development in Information Technology for Librarians, Documentalists and Archivists. París: General Information Programme / Unisist. Acceso en mayo de 2014 en http:// unesdoc.unesco.orgimages/0007/000712/071269eo.pdf.

Derrida, Jacques. (1997). Mal de archivo: una impresión freudiana. Madrid: Trotta, .

Foucault, Michel. La vida de los hombres infames: Ensayos sobre desviacion y dominación. Madrid: La piqueta, 1990. 
Harold, Martin y Richard Omán. (1963). The Logic and Rhetoric of Exposition. Nueva York: Holt, Rinehart and Winston.

Husserl, Edmund. (1985). Investigaciones lógicas, 1. Madrid: Alianza.

Lakatos, Imri. (1983). La metodología de los programas de investigación científica. Madrid: Alianza.

Rendón Rojas, Miguel Ángel. "El objeto de estudio de la bibliotecología no es la biblioteca, así como el objeto de estudio de la medicina no es el hospital. Reflexiones epistemológicas sobre la bibliotecología”. Conferencia presentada en el Programa de Divulgación del Conocimiento Bibliotecológico, CUIB-UNAM, Ciudad de México, el 10 de septiembre de 2014. Acceso el 30 de mayo de 2017 en https://www.youtube.com/watch?v=zEDvhnJA2ng.

tación: intradisciplina, interdisciplina o transdisciplina. México: CUIB-UNAM. Acceso en mayo de 2014 en http://132.248.242.3/ publica/archivos/libros/bibliotecologia_archivistica_documentacion.pdf.

. (2013). "Reflexiones finales". En El objeto de estudio de la bibliotecología/documentación/ciencia de la información. Propuestas, discusión, análisis y elementos comunes. Miguel Ángel Rendón Rojas, coord., 275295. México: IIB-UNAM.

. (2009). "Bibliotecología, cientificidad y desmitificaciones”. Hélice. Revista Venezolana de Ciencias de la Información 1-1.

. (2008). "La ciencia de la información en el contexto de las ciencias sociales y humanas. Ontología, epistemología, metodología e interdisciplina". DataGramaZero - Revista de Ciência da Informação, 9-4.

tecología. México: CUIB-UNAM. 
Rendón Rojas, Miguel Ángel y Silvana Elisa Cruz Domínguez. (2009). "La Archivística y las disciplinas informativas documentales: retos y cuestionamientos epistemológicos". A Ciência da Informação Criadora de Conbecimento, 1: 203-212.

Silva, Armando Malheiro da y Fernanda Ribeiro. (2008). Das "ciências" documentais à ciência da informação: ensaio epistemológico para um novo modelo curricular. Porto: Afrontamento.

Sistema Nacional de Investigadores (2016a). "Convocatoria 2016 para ingreso o permanencia en el SNI". Acceso en marzo de 2016 en http://www.CONACYT.gob. $\mathrm{mx} /$ index.php/sni/convocatorias-CONACYT/convocatorias-sistema-nacional-de-investigadores-sni/convocatorias-abiertas-sni/ingreso-o-permanencia-sni /6329-convocatoria-2016-ingreso-o-permanencia/file.

Sistema Nacional de Investigadores (2016b). "Investigadores vigentes". Acceso en marzo de 2016 en http:// www.CONACYT.mx/index.php/el-CONACYT/sistemanacional-de-investigadores.

Sistema Nacional de Investigadores (2012). "Criterios Internos de Evaluación Aprobados por el Consejo de Aprobación". Acceso en marzo de 2016 en http://2006 -2012.conacyt.gob.mx/SNI/SNI_CriteriosInternosdeEvaluacion/Paginas/default.aspx.

Sola, Tomislav. (1992). "What is museology?". Papers in museology 1 Report from two symposia at the Departamnet of museology, Umea University. What is Museology (1988); Local and Global -two aspects of museum communication (1989). Acta Universitatis Umensis. Umeå Studies in the Humanities, 108: 10-19.

Unesco. (1987). Armonización de la capacitación en materia de Biblioteconomía, Ciencias de la información y Archivística. Paris: Programa General de InformaciónUNESCO. 
Universidad Autónoma del Estado de Morelos. "Facultad de Farmacia". Acceso en marzo del 2016 en http://www. uaem.mx/organizacion-institucional/unidades-academi cas/facultades/farmacia.

van Mensch, Peter. (1992). "Towards a Methodology of Museology", cap. IV. Tesis doctoral, Universidad de Zagreb. Acceso el 30 de mayo de 2017 en http://www. muuseum.ee/uploads/files/mensch04.htm.

Zbyslav Stránský, Zybněk. (2005). Archeologie a muzeologie. Brno: Filozofická Faculta- Masarykova Univerzita v Brne/ Ústav Archeologie a Muzeologie/ Chair of Museology and World Heritage-UNESCO. 
La Archivística y la ciencia de la información documental: Autonomía e interdependencias. Instituto de Investigaciones Bibliotecológicas y de la Información/ UNAM. La edición consta de 100 ejemplares. Coordinación editorial, Carlos Ceballos Sosa; revisión especializada, Francisco Xavier González y Ortiz; cotejo y corrección de pruebas, Valeria Guzmán González; formación editorial y corrección de pruebas, Patricia Pérez Ramírez. Fue impreso en papel cultural de $90 \mathrm{~g}$. Se terminó de imprimir en el mes de agosto de 2017, en los talleres AGYS Alevin, S.C., Retorno de Amores, No. 14, colonia Del Valle, C.P. 03100, delegación Benito Juárez, Ciudad de México. 